LSSA Project

Task Report

5101-57
DOE/JPL-1012-78/7

Distribution Category UC-63B

\section{MASTER}

\title{
Multi-Wire Slurry Wafering \\ Demonstrations
}

Prepared for

Department of Energy

by

Jet Propulsion Laboratory

California Institute of Technology

Pasadena, California

(JPL PUBLICATION 78-37) 


\section{DISCLAIMER}

This report was prepared as an account of work sponsored by an agency of the United States Government. Neither the United States Government nor any agency Thereof, nor any of their employees, makes any warranty, express or implied, or assumes any legal liability or responsibility for the accuracy, completeness, or usefulness of any information, apparatus, product, or process disclosed, or represents that its use would not infringe privately owned rights. Reference herein to any specific commercial product, process, or service by trade name, trademark, manufacturer, or otherwise does not necessarily constitute or imply its endorsement, recommendation, or favoring by the United States Government or any agency thereof. The views and opinions of authors expressed herein do not necessarily state or reflect those of the United States Government or any agency thereof. 


\section{DISCLAIMER}

Portions of this document may be illegible in electronic image products. Images are produced from the best available original document. 
Prepared by the Jet Propulsion Laboratory, California Institute of Technology, for the Department of Energy by agreement with the National Aeronautics and Space Administration.

The JPL Low-Cost Silicon Solar Array Project is sponsored by the Department of Energy (DOE) and forms part of the Solar Photovoltaic Conversion Program to initiate a major effort toward the development of low-cost solar arrays.

This report was prepared as an account of work sponsored by the United States Government. Neither the United States nor the United States Department of Energy, nor any of their employees, nor any of their contractors, subcontractors, or their employees, makes any warranty, express or implied, or assumes any legal liability or responsibility for the accuracy, completeness or usefulness of any information, apparatus, product or process disclosed, or represents that its use would not infringe privately owned rights. 
LSSA Project

Task Report

DOE/JPL-1012-78/7

Distribution Category UC-63B

5101-57

\title{
Multi-Wire Slurry Wafering \\ Demonstrations
}

\author{
C. P. Chen
}

Februaŕy 22, 1978

Approved:

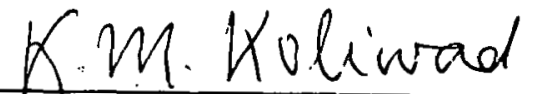

K. M. Koliwald

LSSA Project Large Area Silicon

Sheet Task Manager

Concurrence:

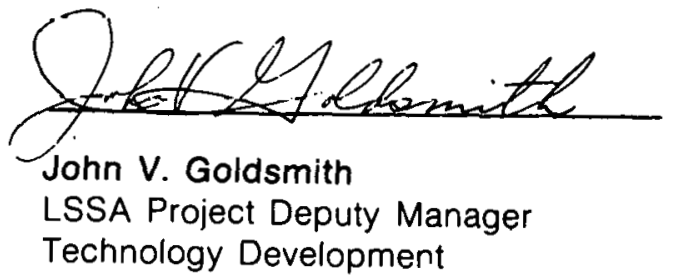

Trepared for

Department of Energy

by

Jet Propulsion Laboratory

California Institute of Technology

Pasadena, Calitornia

(JPL PUBLICATION 78-37) 
THIS PAGE

\section{WAS INTENTIONALLY LEFT BLANK}




\begin{abstract}
A series of ten slicing demonstrations on a multi-wire slurry saw, manufactured by Yasunaga Engineering Company of Japan and distributed by GEOS Corporation of Stamford, Connecticut, was made to evaluate the silicon ingot wafering capabilities. The results revealed that the present sawing capabilities can provide usable. wafer area from an ingot $1.05 \mathrm{~m}^{2} / \mathrm{kg}$ (e.g. kerf width $0.135 \mathrm{~mm}$ and wafer thickness $0.265 \mathrm{~mm}$ ). Satisfactory surface qualities and excellent yield of silicon wafers were found. One drawback is that the add-on cost of producing wafer from this saw, as presentiy used, is considerably higher than the systems being developed by Varian and Crystal Systems for the Low-cost Silicon Solar Array Project (LSSA), Task II, primarily because the Yasunaga saw uses a large quantity of wire. The add-on cost can be signiflicantly reduced by extending the wire life and/or by reuse of properly plated wire to restore the diameter.
\end{abstract}


THIS PAGE

\section{WAS INTENTIONALLY LEFT BLANK}


CONTENTS

I. INTRODUCTION . . . . . . . . . . . . . . . . . . . . 1-1

II. SAW DESCRIPTION . . . . . . . . . . . . . . . . . . . 2-1

III. DEMONSTRATION RESULTS . . . . . . . . . . . . . . . . . 3-I

IV. DISCUSSION . . . . . . . . . . . . . . . . . . 4-1

A. MINIMUM WIRE SIZE. . . . . . . . . . . . . . . . . 4-1

B. WAFER YIELD . . . . . . . . . . . . . . . . . . . 4-1

C. KERF THICKNESS . . . . . . . . . . . . . . . . . . 4-2

D. WAFER THICKNESS . . . . . . . . . . . . . . . . . 4-2

E. WAFER THICKNESS VARIATION ON LOCATION IN INGOT . . . . . . . 4-3

F. WAFER TAPER . . . . . . . . . . . . . . . . . . . . . . . 4-4

G. SURFACE QUALITY . . . . . . . . . . . . . . . . . . 4 44

1. Visual Observation (Macro) . . . . ....... . 4-4

2. Microscopic Examination. . . . . . . . . . . . 4-5

H. WIRE WEAR RATE ..................... . 4-6

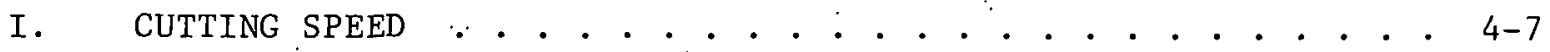

J. SLURRY . . . . . . . . . . . . . . . . . . . . 4-8

K. WAFERING COST . . . . . . . . . . . . . . . . . . . 4-9

V. SUMMARY AND CONCLUSION . . . . . . . . . . . . . . . . . . 5-1

VI. RECOMMENDATIONS . . . . . . . . . . . . . . . . . . . . 6-1 REFERENCES . . . . . . . . . . . . . . . . . . . . . . . . 7-1 FIGURES . . . . . . . . . . . . . . . . . . . . . . $8-1$

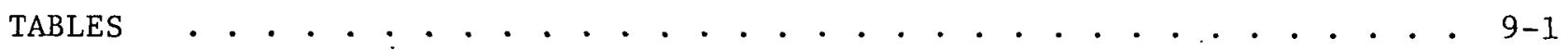

APPENDIX A CUTTING DATA FOR JPL's SILICON INGOT . . . . . . . . . . . . A-1 


\section{FIGURES}

1. Overall photo of Yasunaga Multi-Wire Slurry Saw . . . . . . . . 8-1

2. Relationship among wafer thickness, kerf width and guide roller pitch size... . . . . . . . . . . . . . 8-2

3. Location of thickness measurement on a wafer . . . . . . . . . 8-2

4. Typical cutting marks on the wafers of Demonstration 5 . . . . . 8-3

5. Typical cutting marks on the wafers of Demonstration 7 . . . . . 8-3

6. Macroscopic surface roughness of sample 1-15 measured by Dektak Tracer . . . . . . . . . . . . . . . . . . 8-4

7. Macroscopic surface roughness of sample 5-45 measured by Dektak Tracer . . . . . . . . . . . . . . . . 8-5

8. Macroscopic surface roughness of sample 7-7 measured by Dektak Tracer .. . . . . . . . . . . . . . . . . 8 8-6

9. Macroscopic surface roughness of sample 9-8 measured by Dektak Tracer . . . . . . . . . . . . . . . . 8-7

10. Typical microscopic surface roughness on the wafers of Demonstration 1.... . . . . . . . . . . . 8-8

11. Typical microscopic surface roughness on the wafers of Demonstration 4... . . . . . . . . . . . 8-8

12. Typical microscopic surface roughness on the wafers of Demonstration 6.................. . 8-9

13. Schematic view of surface damage generation with saws . . . . . . . . . . . . . . . . . . . . 8-10

14. Cutting rate and wire loading vs cutting time of Demonstration 1... . . . . . . . . . . . . . . . 8-11

15. Cutting rate and wire loading vs cutting time of Demonstration 2... . . . . . . . . . . . . . . . 8-12

16. Cutting rate and wire loading vs cutting time of Demonstration 4... . . . . . . . . . . . . 8-13

17. Cutting rate and wire loading vs cutting

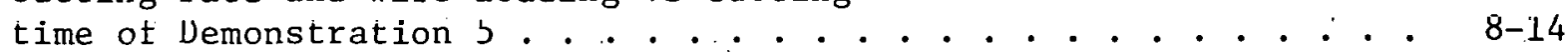

18. Cutting rate and wire loading vs cutting time of Demonstration 6... . . . . . . . . . . . . . 8-15

19. Cutting rate and wire loading vs cutting time of Demonstration 7. . ................. 8-16 
TABLES

1. Specification of Yasunaga Multi-Wire Slurry Saw . . . . . . . . 9-1

2. Cutting conditions and result of Demonstration 1 . . . . . . . 9-2

3. Cutting conditions and result of Demonstration 2 . . . . . . . 9-3

4. Cutting conditions and result of Demonstration 3 . . . . . . . . 9-4

5. Cutting conditions and result of Demonstration 4 . . . . . . . 9-5

6. Cutting conditions and result of Demonstration 5 . . . . . . . 9-6

7. Cutting conditions and result of Demonstration 6 . . . . . . . 9-7

8. Cutting conditions and result of Demonstration 7 . . . . . . . 9 9-8

9. Cutting conditions and result of Demonstration 8 . . . . . . . 9-9

10. Cutting conditions and result of Demonstration 9 . . . . . . . . . 9-10

11. Cutting conditions and result of Demonstration 10 . . . . . . . 9-11

12. Variables affecting economical silicon wafer production . . . . . 9-12

13. Summary of wafer and kerf thickness as function of the sizes of wire; abrasive and guide roller pitch . . . . . . . . . . . 9-13

14. Average value of wafer thickness at the location of measurement, $\mathrm{mm}$. . . . . . . . . . . . . . . . . . 9-14

15. Microscopic surface roughness and damage of several samples
sliced by the multi-wire-slurry saw . . . . . . . . . . . . 9-14

16. Summary of cutting rate ( $\mu \mathrm{m} / \mathrm{min}$. per $\mathrm{gm}$ of each $\mathrm{cm}$ of wire 1oad)

17. Steel wire prices . . . . . . . . . . . . . . . 9-15

18. Milasil silicon carbide abrasive prices . . . . . . . . . . 9-16

19. Prices of rollers . . . . . . . . . . . . . . . . 9-16

20. Cost of wire, abrasive and rollers for the demonstrations . . . . 9-17 


\section{SECTION I}

INTRODUCTION

In the present solar cell technology, the most efficient solar cells are produced from single crystal, defect-free silicon wafers. The wafering technique to produce silicon wafers from a single crystal ingot becomes one of the important considerations for Low-cost Silicon Solar Array (LSSA) project, in that minimum kerf loss is required to achieve the required sheet cost. The conventional cutting techniques, such as O.D. saws and I.D. saws, do not appear capable of meeting the low kerf requirements. Efforts are underway to develop and evaluate several multi-sawing techniques, such as the multiblade slurry sawing process (Reference 1) and multi-wire fixed diamond slicing method. (Reference 2). A new multi-wire-slurry wafering machine is available and developed for semiconductor manufacturing. Its potential for the use in LSSA project, Task II, needs to be evaluated.

In this report, the results of a series of ten silicon wafering demonstrations on a multi-wire-slurry slicing system by Yasunaga in Japan will be discussed, and the surface damage on the as-sawed wafers will be examined to evaluate the quality of wafers produced by this system. 


\section{SECTION II}

\section{SAW DESCRIPTION}

The saw under evaluation is a multi-wire slurry type, Model No. YQ-100, manufactured by Yasunaga Engineering Company of Japan and distributed by the GEOS Corporation in Stamford, Connecticut. It is also called a "GEOS" saw. This saw is capable of slicing work pieces up to $4 \times 4 \times 4-i n$. into 250 wafers simultaneously with minimum kerf 1oss. The overall picture of the saw is shown in Figure 1. The present capabilities and specification of this saw are shown in Table 1. Each wire, from 5000 to $75,000 \mathrm{ft}$, was wound on a reel, routed around a rock-arm tensioning device, a wire guide cartridge, and then rewound on a take-up reel. The guides are grooved to achieve the desired wafer thickness. The continuous wire forms multiple wire loops around the wire guides.

In operation, the ingot is cemented to a mounting block. The ingot is positioned upon a platform which raises the workpiece to the multiple wires under constant, but adjustable load.

A recirculating, temperatured controlled, abrasive slurry is pumped to the cutting area. Slicing is accomplished by oscillating the multiple wires across the work and flushing away the kerf with the abrasive slurry.

The following working conditions are adjustable over wide ranges to meet the desired specifications:
(1) Wire diameter
0.08 to $0.5 \mathrm{~mm}$
(2) Wire Guide Pitch
$0.4,0.5,0.6,0.7,0.8,0.9$,
(3) Abrasive Material
SiC, Diamond
(4) Abrasive Particle Size
Sic: $5,9,12,15,20,25,30 \mu \mathrm{m}$
(5) Cutting Pressure
Varialite, up to tensile strength
(6) Wire Feed Rate
42 to $112 \mathrm{~m} / \mathrm{min}$
(7) Multiple Wire Stroke Rate
30 to 80 cycles/min

Optimization of these variables would be required for the reduction of wafering cost in the LSSA project. 
In order to evaluate the capability of the multi-wire-slurry saw, a series of ten demonstrations were performed by Yasunaga Engineering Company in Japan through a contractual arrangement with GEOS Corporation. This series of demonstrations was conducted under conditions specified by the Jet Propulsion Laboratory (JPL) on material provided by JPL. The silicon ingots, provided by JPL for each demonstration, were approximately $3 \mathrm{in.}$ in diameter and 1 in. long, cut from one Czochralski silicon single crystal supplied by Siltec Corp., Men1o Park, Ca. Several properties of this crystal are as follows:

$$
\begin{aligned}
& \{100\} \text { orientation } \\
& \text { P-type, Boron doped } \\
& \text { Resistivity at top }=2.7 \mathrm{ohm}-\mathrm{cm} \\
& \text { Resistivity at bottom }=2.0 \mathrm{ohm}-\mathrm{cm}
\end{aligned}
$$

The JPL specified slicing conditions and the performed conditions for each of these ten demonstrations are given in Tables 2 through 11 , respectively. The results of these demonstrations are also summarized in Tables 2 through 11. The cutting data reported by Yasunaga are in Appendix A. 


\section{SECTION IV}

\section{DISCUSSION}

\section{A. MINIMUM WIRE SIZE}

Demonstration 10. (Table 11) showed that this saw failed to slice silicon with $0.1 \mathrm{~mm}$ ( 0.004 in.) diameter steel wire due to wire breakage. The fact that the wire broke very quickly $(13 \mathrm{~min})$ raises doubt as to the conclusiveness of this test. Further development is necessary for the use of this size steel wire. On the other hand, tungsten wire may be used if the smaller wire is required. and cost goals can be met. The minimum steel wire size for slicing silicon without wire breakage is $0.12 \mathrm{~mm}$ ( $0.0047 \mathrm{in.}$ ).

\section{B. WAFER YIELD}

The wafer yield is defined as a ratio of the unbroken wafer and total number of wafer in the demonstration. The wafer yield ratio for each demonstration is given in Tables 2 through 11 and was generally greater than 95 percent. Demonstration 10 failed because the $0.10 \mathrm{~mm}$ diameter wire broke after 13 min of slicing. Effort was made to rewire, however, the wire broke again after $1 \mathrm{hr}$ and $23 \mathrm{~min}$ of restart. Demonstration 8 (Table 9) failed because the wire was broken when the supporting dummy glass pieces came loose. Demonstration 5 (Table 6) has a relatively low yield which may have resulted from the excessive surface roughness and thickness variation. These wafer imperfections were found to have resulted from the improper control of wire cutting load. Except these three slicings, all the other slicings have demonstrated the potential of excellent wafer yield of this wafering machine. It should be pointed out that one major drawback is the possible loss of the whole ingot if wire breakage occurs during the slicing. The slicing systems being developed by Varian and Crystal Systems will lose two wafers if any wire breaks. This problem requires investigation to determine the probability of failure and restart potential. 


\section{KERF THICKNESS}

The average kerf thickness for each slicing is given in Tables 2 through 11 and is summarized in Table 13. These values are taken from the data reported by Yasunaga (Appendix A).

As shown in Tables 2 through 11, the kerf thickness depends directly upon the combination of wire and abrasive sizes used for the slicing. Additional variables, such as wire feed rate, abrasive material types, etc, which were suggested (Reference 3) by GEOS as shown in Table i2, were not evaluated in these demonstrations.

In these demonstrations, the effects of wire, abrasive and guide roller pitch sizes on the kerf thickness and wafer thickness are defined in Figure 2 and summarized in lable 13. It is found that:

$$
B-C \cong 3 D
$$

or

$$
B \cong C+3 D
$$

Therefore, the kerf thickness (B) of a slicing can be estimated from wire size (C) plus three times the abrasive size (D). The wire size is thus the dominant factor controlling kerf loss.

\section{WAFER THICKNESS}

The average wafer thickness for each slicing demonstration is given in Tables 2 through 11 and is summarized in Table 13. The value is taken from the average wafer thickness data at position 5 (See Figure 3) reported by Yasunaga (Appendix A). The wafer thickness and kerf width of Demonstration 8 were not measured, since the wafering conditions were re-evaluated in Demonstration 9. An . effort was made to measure wafer and kerf thicknesses on the ingot for Demostration 10 by optical microscopy. It was found that the average wafer thickness and kerf width were 0.250 and $0.13 \mathrm{~mm}$, respectively. Wafer thickness of a slicing should be related to guide roller pitch size and kerf thickness. This relationship can be illustrated in Figure 2 and expressed as:

$$
E=A+B
$$

or

$$
\text { Wafer thickness }+ \text { kerf thickness }=\text { Roller Pitch Size }
$$


The slicing results, as shown in Table 13, are reasonably in agreement with the relationship of Equation 2. By substitution of Equation 1, into 2, one finds that

$$
A \approx E-(C+3 D)
$$

Therefore,

$$
\begin{aligned}
\text { Wafer thickness }= & \text { Guide Roller Pitch Size } \\
& - \text { Wire Diameter } \\
& -3 \text { Abrasive Particle Size }
\end{aligned}
$$

The minimum pitch size of the guide roller presently available is $0.4 \mathrm{~mm}$ $(15.75$ mils). Special finer pitch rollers would require development and evaluation. If we use a $0.12 \mathrm{~mm}$ diameter wire and $0.005 \mathrm{~mm}$ abrasive on $0.4 \mathrm{~mm}$ guide rollers, we will obtain a wafering of

$$
\begin{aligned}
& \text { Kerf width }=0.135 \mathrm{~mm}(5.3 \mathrm{mils}) \\
& \text { and Wafer thickness }=0.265 \mathrm{~mm}(10.4 \mathrm{mils})
\end{aligned}
$$

These values exceed the present sawing capabilities of Varian and Crystal System, and provide wafers at $1.05 \mathrm{~m}^{2} / \mathrm{kg}$.

\section{E. WAFER THICKNESS VARIATION ON LOCATION IN INGOT}

Since the ingot is sliced by one continuous wire which forms multiple wire loops around the wire guide, the wafers at the front side are sliced by the fresh wire while the wafers at the rear side are sliced by the worn wire. Therefore, the wafers at the front have the potential of being thinner than those at the rear side of the ingot.

The slice thickness data provided by Yasunaga (Appendix A) indicated no appreciable wafer thickness variation as a function of the location in ingot slicing. Considerable thickness variation of wafers was found in Demonstration 5 , but this variation does not correlate to the wire wearing as discussed above. Neverthless, the effect of wire wear on the wafer thickness variation (if existent) can be corrected by the programmed pitch distance of the guide roller. 
F. WAFER TAPER

In each ingot slicing demonstration, the wafer thickness was determined on five locations on the selected wafers for determining the taper. The locations of thickness measurements are shown in Figure 3. The measured data are provided by Yasunaga in Appendix A. The average value of selected 10 to 13 wafers at each location of thickness measurement for each slicing demonstration is given in Table 14. The results indicate that the wafer taper is not appreciable. It should be pointed out that variations in the wafer thickness did not correlate with location on the wafers. The minimum wafer thickness can occur at the top, bottom or the middle of the slices. The wafer taper in Demonstrations 5 and 7 was found to be approximately $0.020 \mathrm{~mm}$ in some wafers. However, in ail the other demonstrations the taper was approximately 0.005 . mm or less.

G. SIIRFAF,F, NitATITTY

As shown in Table 12, GEOS reported that the dominant factors affecting the surface quality of wafers are:

(1) Wire diamétér colerance

(2) Wire stroke rate

(3) Abrasive material

(4) Abrasive grit size

(5) Abrasive size tolerance

(6) Cuting pressure

Based on these factors, visual observation (macro) and optical microscope examination as well as scanning electron microscopy were utilized to examine the surface quality of wafers for various cutting conditions. The results of these examinations are as follows:

1. Visual Observation (Macro)

(1) Abrasive grit size appears to have the most significant effect on the surface condition of wafers. Demonstrations 4 and 5 were 
sliced by $5 \mu \mathrm{m}$ ( 3000 grit) SiC abrasive while all the other ingots were sliced by $10 \mu \mathrm{m}$ (非1500 grit). SiC abrasive. The macro surface finish on the wafers of Demonstrations 4 and 5 should be finer than those sliced by $10 \mu \mathrm{m}$ abrasive. However, visual observation showed the opposite. A considerably greater amount of cutting marks were observed on the wafers of Demonstrations 4 and 5 than those of other ingots. Figure 4 shows the typical cutting marks on the wafers of Demonstration 5 .

(2) All the wafers sliced by using $10 \mu \mathrm{m}$ SiC abrasive have an excellent surface quality, except some minor sawing marks were found on wafers in Demonstrations 7 and 9 . Some sawing marks shown on the wafers of Demonstration 7 at the area of the end of slicing may be due to some unexplained hesitations of wire at that point, as shown in Figure 5. A wire cutting mark was found on the wafers. of Demonstration 9 at approximately $18 \mathrm{~mm}$ depth from the starting point. This mark was reported to result from the abrupt change of wire load (cutting pressure). Therefore, uniform control of wire loading is an important factor affecting the macro surface finish of the wafer.

The macroscopic surface roughness of several demonstrations was measured by a surface contour analyzer.* The analyzer was traced along the diameter of a wafer in the cutting direction, perpendicular to the wire cutting marks. The typical surface roughnesses of Samples $1-15,5-45,7-7$ and $9-5$ are shown in Figures 6 , 7,8 and 9 , respectively. As shown in Figure 6 , the maximum irregularity at the center area of wafer $1-15$ is approximately $9 \mu \mathrm{m}$. Figure 7 reveals the surface condition of specimen 5-45 to have severe irregularities. The worst roughness occurred at center area of the wafer to be $70 \mu \mathrm{m}$. Figure 8 shows a taper of $22 \mu \mathrm{m}$ over a distance of approximately $10 \mathrm{~mm}$ at the lower half of the Wafer 7-7. The sawing marks on this wafer at the area of the end of slicing was found to be approximately $12 \mu \mathrm{m}$. Figure 9 shows the very good surface finish of Wafer 9-5 except for a step of $25 \mathrm{\mu m}$ at approximately $18 \mathrm{~mm}$ from the starting point, where a. sawing mark was observed. The importance of these surface contour analyzer results to cell performance is not clear.

2. Microscopic Examination

a. Micro surface Roughness. The microscopic surface roughness of wafers sliced under various cutting conditions was examined by a stereo optical

ॠTrade name, "Dektak Tracer," manufactured by Sloan Corp., Sunnyvale, CA. 
microscope as well as by scanning electron microscope (SEM). The typical micro surface roughness of Demonstrations 1, 4, and 6 are shown in Figures 10, 11, and 12, respectively, by SEM examination. At the present time, no standard method for determination of the surface roughness has been established. In order to make a comparison on the microscopic surface roughness under various cutting conditions, the average surface irregularity spacing, estimated from SEM photos, of several samples are given in Table 15 .

b. Surface Damage. The surface damage of a wafer was examined to determine the depth and nature of the saw-induced damage from the multi-wire-slurry slicing process. A method to reveal the damage by angle lapping and Sirtl etching was reported by Digges, et al (Reference 4). Optical microscopy was utilized to examine several selected samples prepared by this method. Their results are given in Table 15. Attempts have been made to relate the surface damage of wafer to the wafering variables. One can find that

Surface Damage $=$ Abrasive size $+\mathrm{X}$

where $X$ is a small value and a function of cutting. rate and wire size. Further investigation is necessary to identify these factors. However, present demonstration results imply that the wafer surface damage is approximately equal to one abrasive particle size under norma $\perp$ wafering conditions. 'l'he wafer surface damage from this wafering machine appears to be less than those produced by the Varian saw $(\sim 18 \mu \mathrm{m})$ (Reference 1a). A suggested explanation is illustrated in Figure 13.

\section{H. WIRE WEAR RATE}

The wire wear rate of each demonstration was given in the Yasunaga cutting data report (Appendix A). It is summarized as follows:

(1) In Demonstrations 1, 2, 8 and 9, approximately 6 to $7 \mu \mathrm{m}$ reduction in diameter was found by using $10 \mu \mathrm{m}$ abrasive under standard wire loading ( $20 \mathrm{gm} / \mathrm{cm} /$ wire). 
(2) $5 \mu \mathrm{m}$ reduction in diameter was found by using $5 \mu \mathrm{m}$ abrasive under standard wire loading as in Demonstrations 4 and 5.

(3) Approximately $9 \mu \mathrm{m}$ wearing was found by using:10 $\mathrm{\mu m}$ abrasive under $23 \mathrm{gm} / \mathrm{cm} /$ wire of wire loading as shown in Demonstrations 3 and 7 .

Therefore, the wire wear rate appears to be dependent upon the abrasive particle size and wire loading and independent of the wire size. The larger the abrasive size, the greater wire wear rate will be. A similar effect of wire loading on wearing was found. It can be estimated that the wire wearing is approximately one abrasive particle size at the cutting loads and feed rates used here. Limits of wear rate, at which breakage occurs, were not reached.

The life of the wire is an important factor affecting the total cost of producing silicon solar cells since a major add-on cost in the use of this slicer is the cost of the wire.

N. Mardesich and M. Leipold (Reference 5) made an evaluation of a used wire from a previous silicon ingot demonstration. They found that the reduction in diameter during silicon ingot slicing appears to be the only effect. There is not an accompanying material deterioration or loss in physical properties. They suggested that the wire might be reused at lower loads or be plated to restore the diameter.

\section{CUTTING SPEED}

As reported by GEOS in Table 12, the dominant factors affecting the cutting speed of slicing are:
(1) Wire Size
(2) Wire stroke rate (cycle rate)
(3) Abrasive material (type of abrasive)
(4) Abrasive grit size
(5) Abrasive size tolerance
(6) Ratio of abrasive to suspendor (abrasive concentration)
(7) Cutting pressure (wịe load) 
Among these factors, wire stroke rate, abrasive material type, abrasive size tolerance and abrasive concentration in the slurry were not evaluated in these demonstrations. In order to evaluate the effect of wire size, abrasive grit size and cutting pressure (wire load) on the cutting speed of this slicing system, the cutting rate and wire loading versus cutting time of several ingot slicing are plotted in Figures 14 through 19. In these figures, the cutting rate versus wire loading at one-half ingot slicing will be used to make the comparison. The cutting rate per wire load at one-half. ingot slicing is summarized in Table 16. These data indicate that greater abrasive size and wire load will increase cutting rate; however, the total cutting time of the demonstrations is not only determined by the cutting rate at half ingot but also by the control of wire load by adding and removal of weights.

It can be summarized that the maximum cutting speed is approximately $8 \mu \mathrm{m} / \mathrm{min}$ and $11 \mu \mathrm{m} / \mathrm{min}$ for 5 and $10 \mu \mathrm{m}$ abrasive, respectively, under one $\mathrm{gm} / \mathrm{cm}$ of wire load.

\section{J . SLURRY}

l'he slurry used in the slicing demonstrations consists of SiC abrasive and lapping oil in a specified ratio. The lapping oil was John Crane $3 \mu \mathrm{m}$ lapping vehicle, supplied by Crane Packing Co., Morton Grove, IL. The ratio of abraslve and lapping oil, by weight, for each demonstration is given in Tables 2 through 11. The effect of abrasive concentration in the slurry on the cutting speed and wafer qualities was not examined quantitatively..

The reuse of slurry was evaluated in Demonstrations 6 through 10 . The result showed that no deterioration in cutting capability of the reused slurry be found. 


\section{K. WAFERING COST}

The variables affecting the wafering cost reported by GEOS Corporation are given in Table 12. The most significant add-on cost for this wafering will be the cost of the expendable materials as follows:
(1) Wire
(2) Abrasive
(3) Roller-guide, idler and $\mathrm{V}$

The costs of steel wire, silicon carbide abrasive and rollers are given in Tables 17, 18 and 19, respectively. The cost of wire per cutting area used in the demonstrations is given in Table 20. Since the lives of the abrasive and rollers have not been evaluated, their cost per cutting area cannot be estimated. The total costs of abrasive and rollers as used in the demonstrations are given in Table 20. The present technologies of multiblade-slurry system (Reference 6) and the multi-wire-fixed abrasive system (Reference 7) have estimated the add-on cost to be $\$ 35.00 / \mathrm{m}^{2}$ and $\$ 11.57 / \mathrm{m}^{2}$, respectively. Therefore, the slicing cost $\left(\$ 68 / \mathrm{m}^{2}\right.$ for wire alone) of the multi-wire-slurry system in its present state is too high. Further evaluation to determine the limits of wire wear as well as means of minimizing it are needed. As mentioned previously, the wire of the Yasunaga saw has the potential of being reused by proper plating to restore the diameter. 


\section{SECTION V}

\section{SUMMARY AND CONCLUSION}

(1) The minimum size of steel wire successfully used in multi-wire slurry demonstrations for silicon ingot slicing without breakage was found to be $0.12 \mathrm{~mm}$ ( $0.0047 \mathrm{in.}$ ).

(2) The kerf thickness of this sawing can be estimated by one wire diameter plus three times the particle size of abrasive and was demonstrated as low as $0.135 \mathrm{~mm}$.

(3) The wafer thickness of this sawing is estimated by guide roller pitch size minus the kerf width and reached $0.28 \mathrm{~mm}$.

(4) The present capabilities of this slicer can product usable wafer area from an ingot of $1.05 \mathrm{~m}^{2} / \mathrm{kg}$. (10 mils wafer thickness with 5 mils kerf loss). This wafering capability is consistent with the objectives of LSSA Task II.

(5) The wafer thickness variation and taper were shown to be consistent with expected ce11 requirements.

(6) This slicer has demonstrated the potential of excellent wafer yield.

(7) The wafer surface damage is approximately equal to one abrasive particle size under normal wafering conditions.

(8) The results indicate that wire wearing is approximately one abrasive particle size at the maximum cutting load and wire feed rate.

(9) The maximum cutting speed of this slicer is approximately $8 \mu \mathrm{m} / \mathrm{min}$ and $11 \mu \mathrm{m} / \mathrm{min}$ for $5 \mu \mathrm{m}$ and $10 \mu \mathrm{m}$ abrasive, respectively, under one $\mathrm{gm} / \mathrm{cm}$ of wire pressure.

(10) The add-on cost of the Yasunaga saw as presently used is considerably higher than the systems being developed by Varian and Crystal Systems for LSSA Task II, primarily since the Yasunaga saw uses a large quantity of wire. The reuse of the wire was not investigated. It is believed that the add-on cost can be significantly reduced by extending the wire life and/or by the reuse of properly plated wire to restore the diameter. By such means, the slicing goal of LSSA Task II might be met. 


\section{SECTION VI}

\section{RECOMMENDATIONS}

From the results of these demonstrations, the multi-wire-slurry slicing machine has been shown to have potential for use of silicon ingot wafering in the LSSA Project, Task II. It is recommended that several important wafering parameters be evaluated as follows:

(1) Determine more completely the wire wear limits, particularly with full size ingots

(2) Evaluate 0.30 and $0.35 \mathrm{~mm}$ roller pitch operation

(3) Determine the usability of $0.10 \mathrm{~mm}$ wire

(4) Determine abrasive/slurry requirements, limits and costs

(5) Optimize the cutting time as a function of wire and abrasive sizes

(6) Define the proper mounting method for silicon ingot and determine the time required for mounting ingot

(7) Determine the life and cost of minor components such as rollers

(8) Evaluate the cost factors as a function of cutting process parameters and ancillary equipment variables

(9) Modify wiring system for minimizing ingot loss due to any wire breakage and evaluate restart potential

(10) Investigate wire plating. 


\section{REFERENCES}

1. a. S. C. Holden, "Slicing of Silicon Into Sheet Material," First Annual Report, Varian Associates, ERDA/JPL 954374-76/3, September 27, 1976 .

b. S. C. Holden and J. R. Fleming, "Slicing of Silicon Into Sheet. Materials," Sixth Quarterly Report, Varian Associates, ERDA/JPL 954374-77/3, September 30, 1977.

2. F. Schmid and C. P. Khattak, "Heat Exchanger-Ingot Casting/Slicing Process," Final Report, Crystal Systems, Inc., ERDA/JPL 954373-77/4, December 1, 1977.

3. W. Carl, "Preliminary Proposal for Development Contract(s)," GEOS Corp. letter to Dr. John Zoutendyk of JPL, April 19, 1977.

4. T. G. Digges, Jr., M. H. Leipold, K. M. Koliwad, G. Turner and G. D. Cumming, "Some Observations on the Characteristics of Low-Cost Silicon Sheets," Proceedings of 12th Annual Photovoltaic Specialists Conference, Baton Rouge, La. Nov. 1976.

5. N. Mardesich and M. Leipold "GEOS Corporation Multi-Wire Silicon Slicer," IOM to G. Cumming, April 13, 1977.

6. S. C. Holden "Slicing of Silicon into Sheet Materia1," Twelfth Monthly Technical Progress Report, Varian Associates, JPL 954374, June 17, 1977.

7. F. Schmid and C. P. Khattak, "Heat Exchanger-Ingot Casting/Slicing Process," Eighth Quarterly Progress Report, Crystal Systems, Inc., ERDA/JPL 954373-77/3, October 1, 1977. 


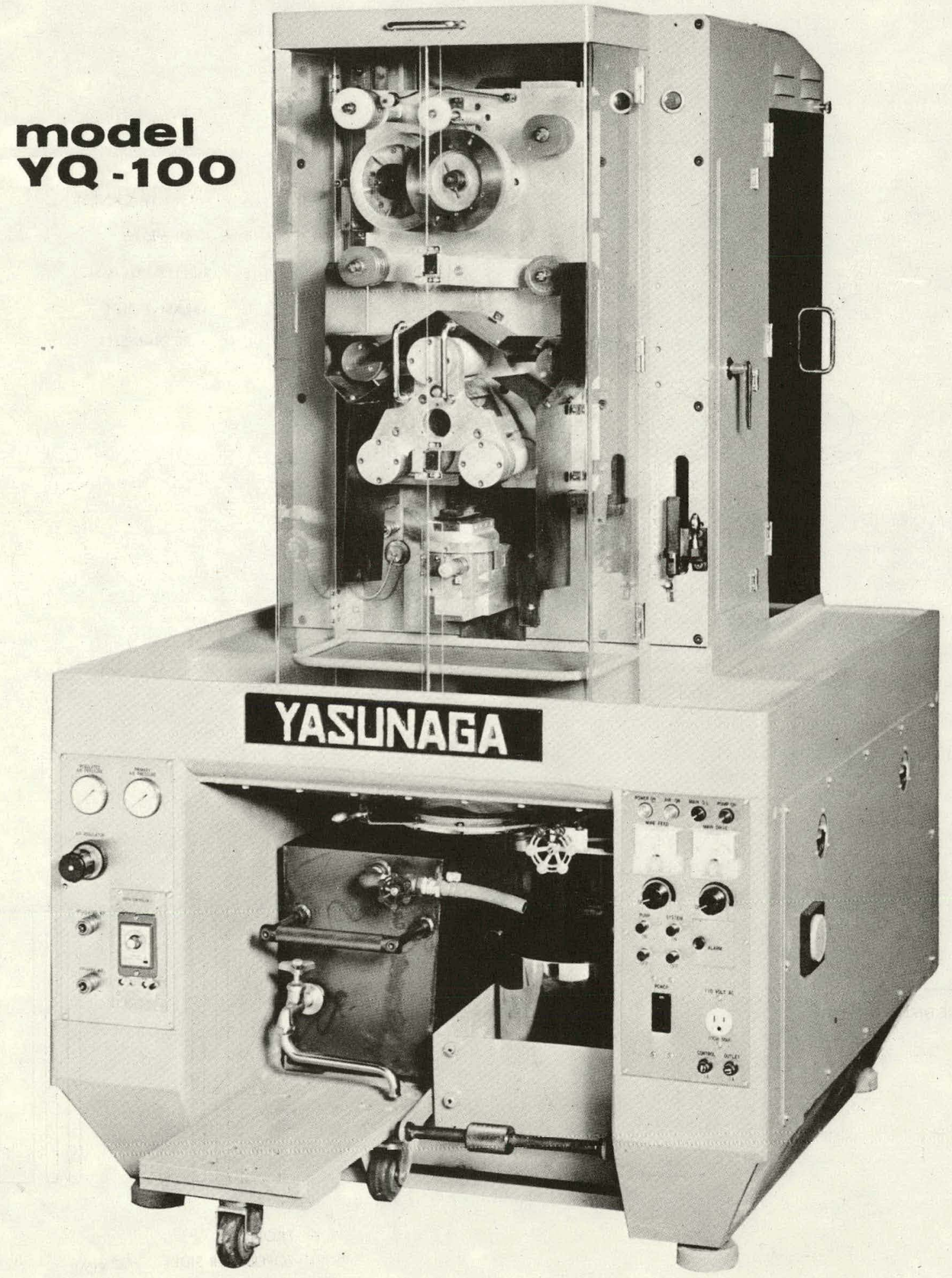

Figure 1. Overall photo of Yasunaga Multi-Wire Slurry Saw 


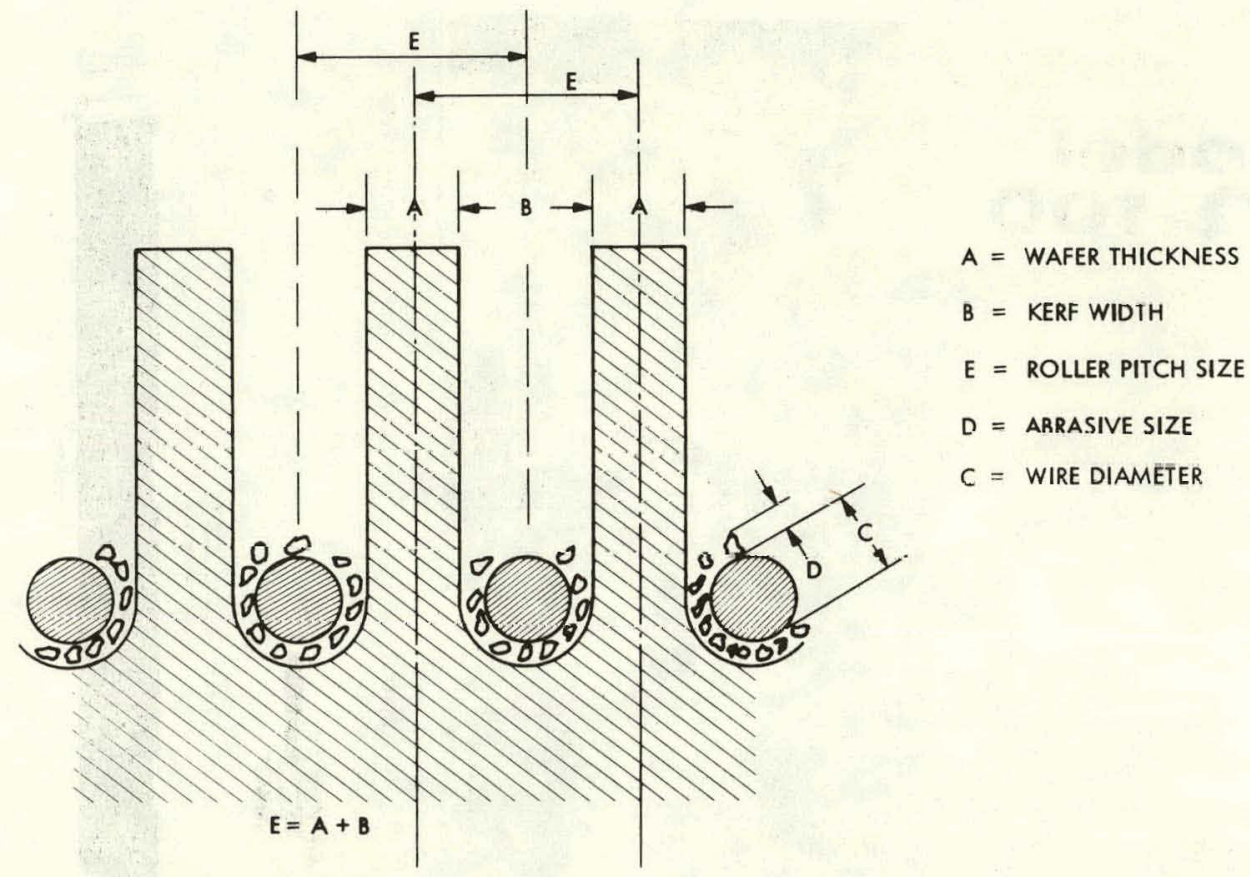

Figure 2, Relationship among wafer thickness, kerf width and guide roller pitch size

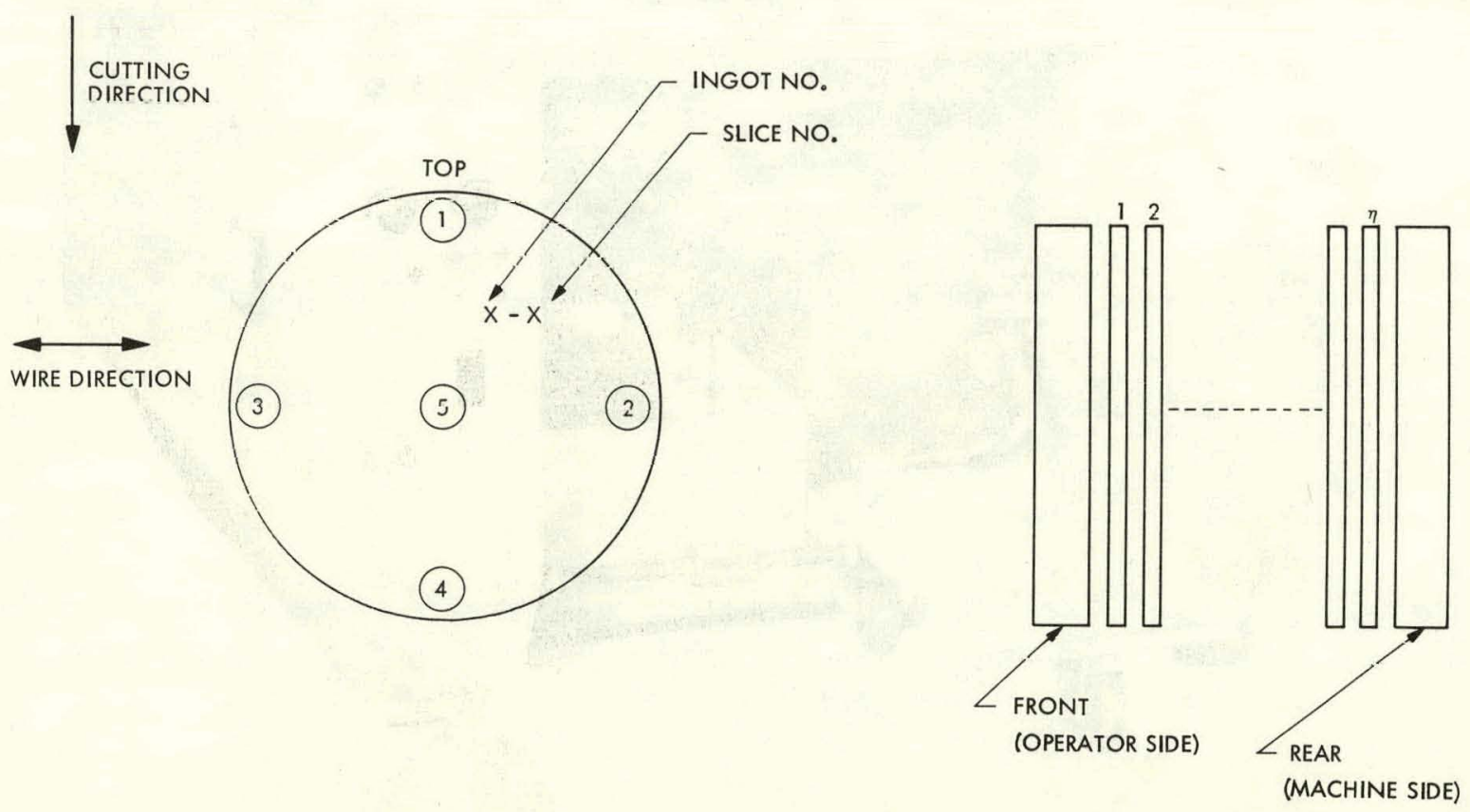

Figure 3. Location of thickness measurement on a wafer 


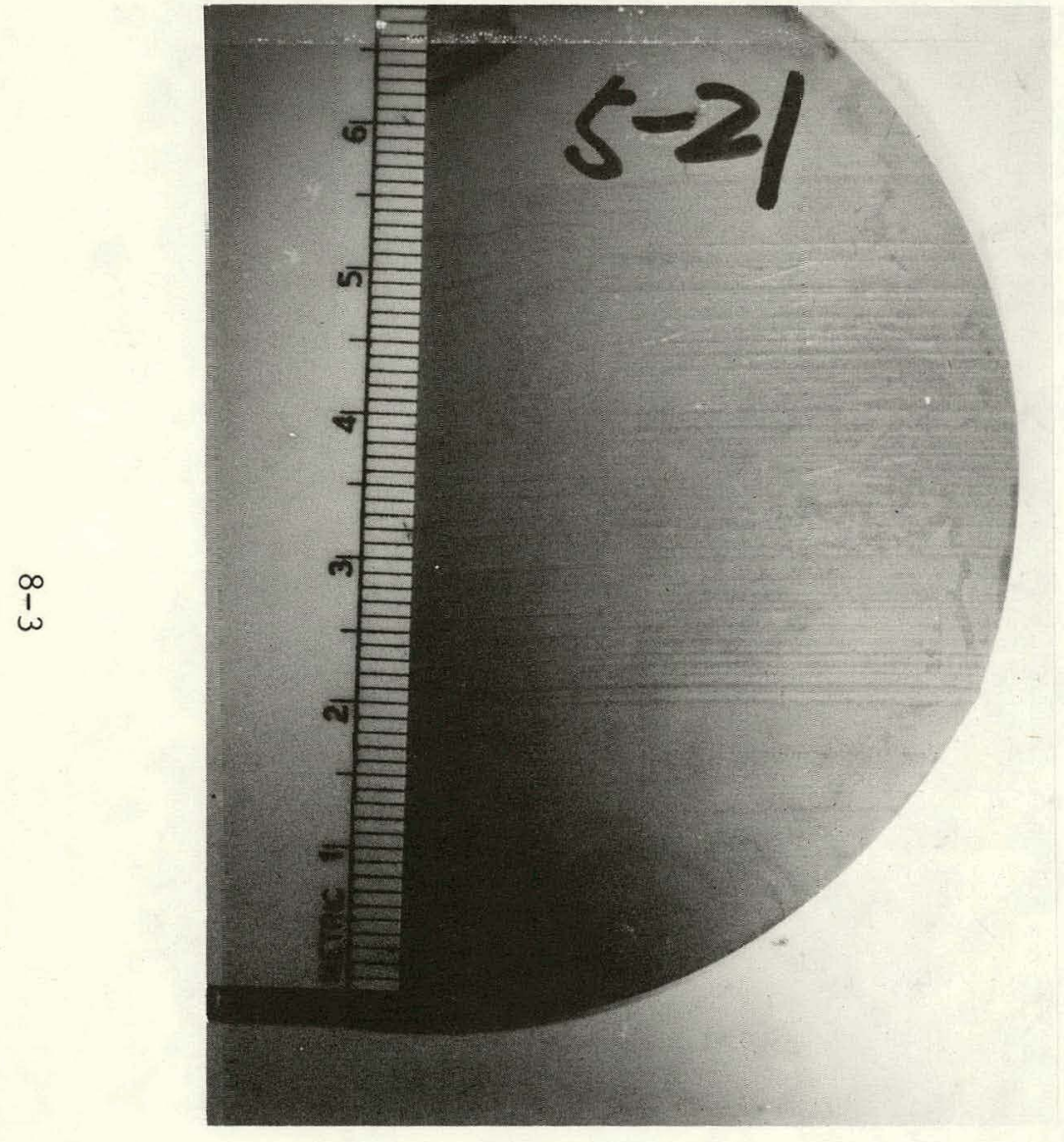

Figure 4. Typical cutting marks on the wafers of Jemonstration 5

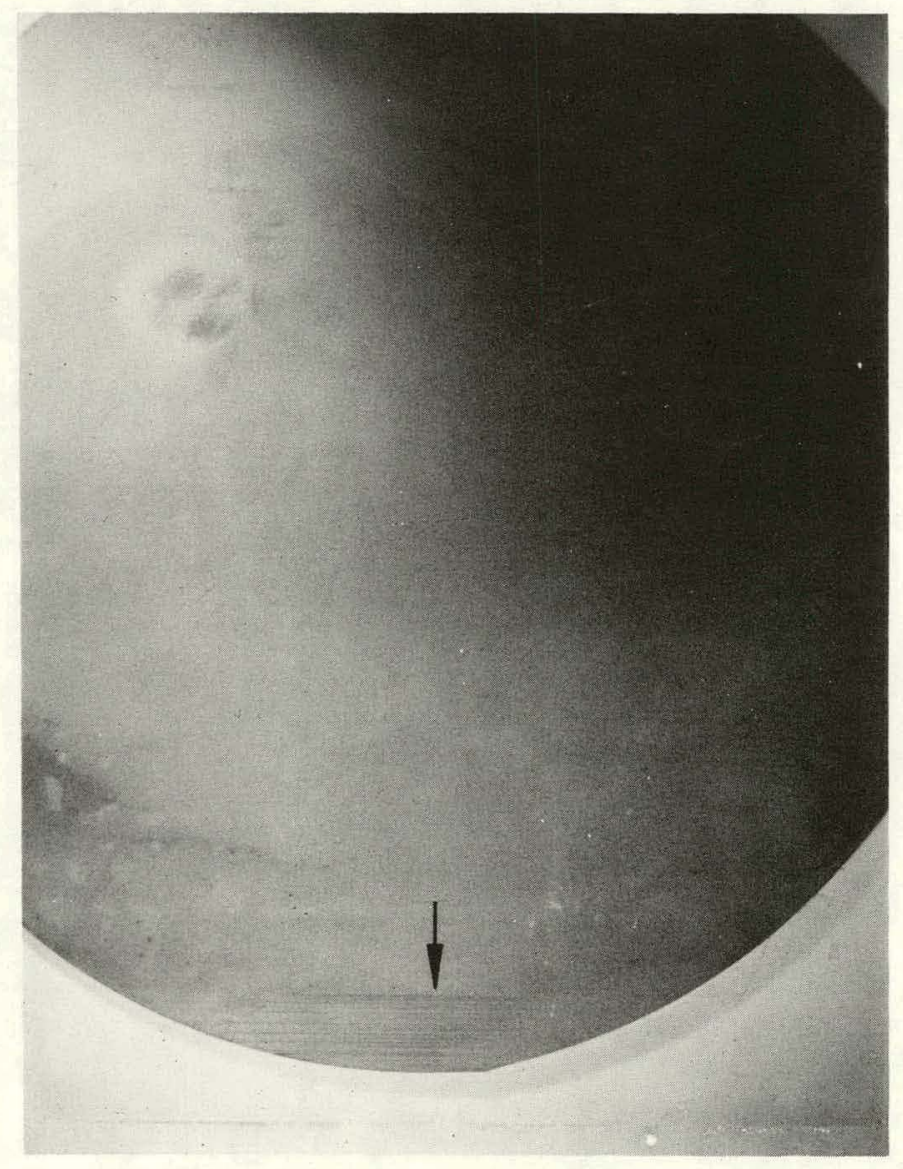

Figure 5. Typical cutting marks on the wafers of Demonstration 7 


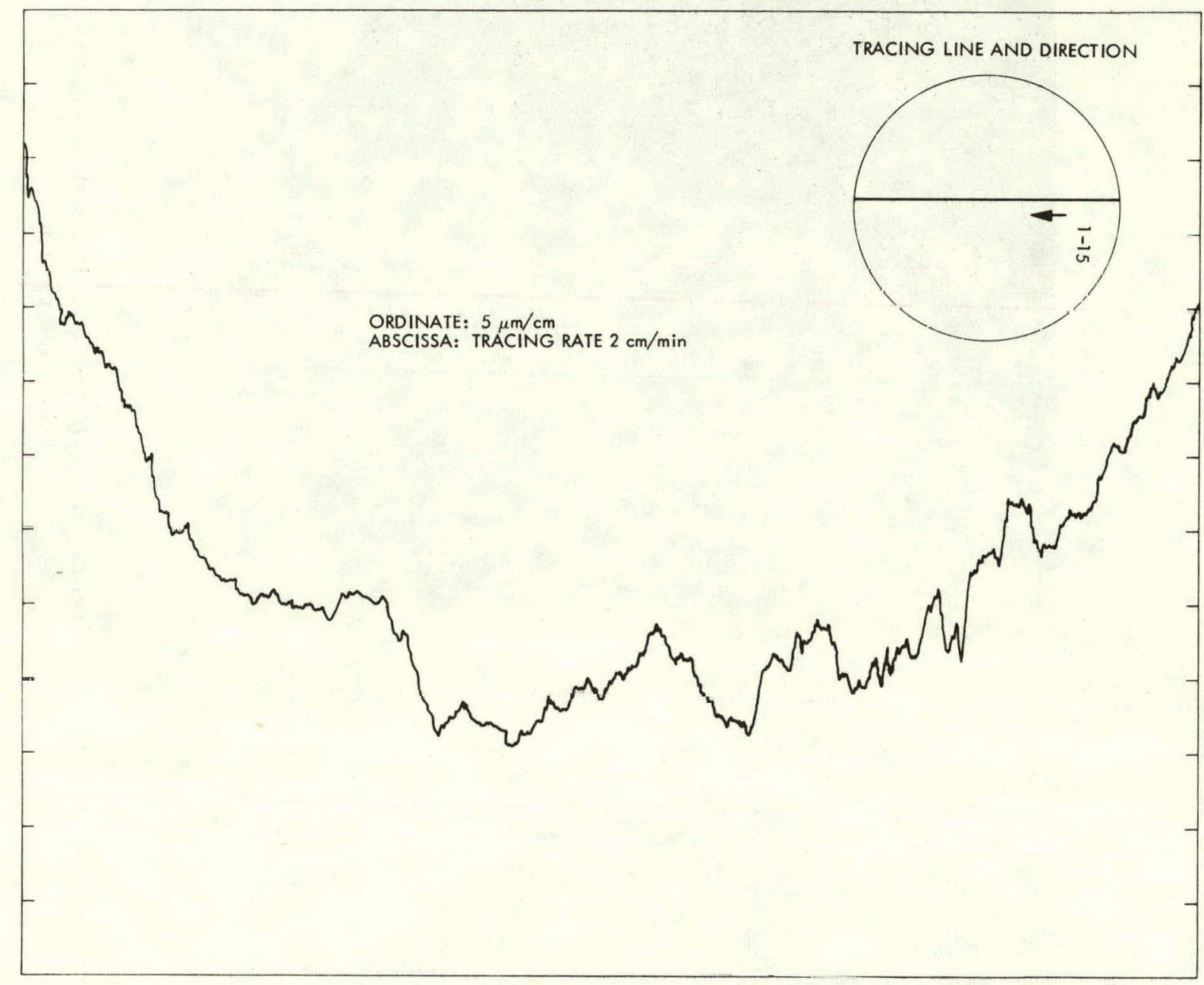

Figure 6. Macroscopic surface roughness ut sample 1-15 measured by Dektak Tracer 


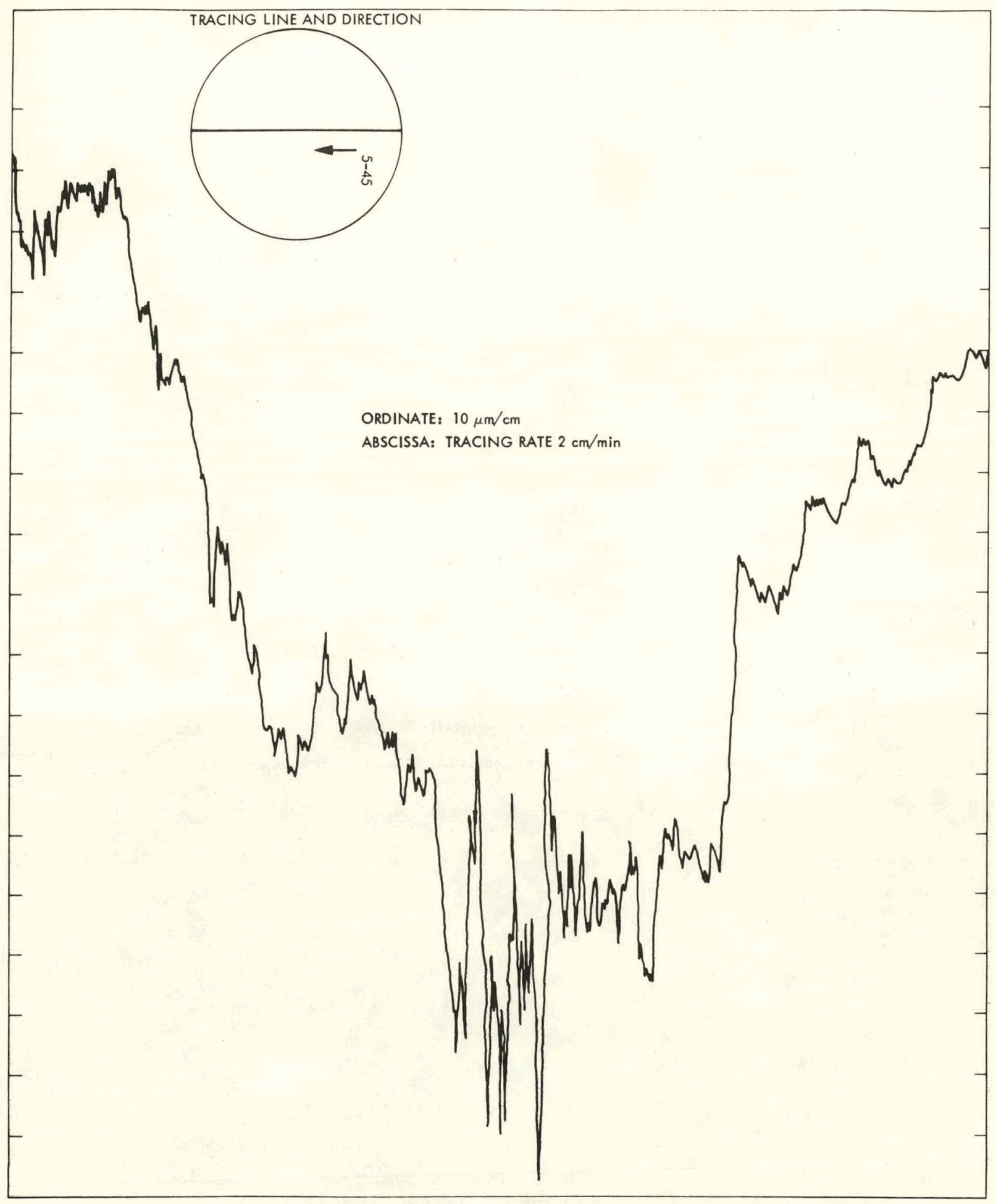

Figure 7. Macroscopic surface roughness of sample 5-45 measured by Dektak Tracer 


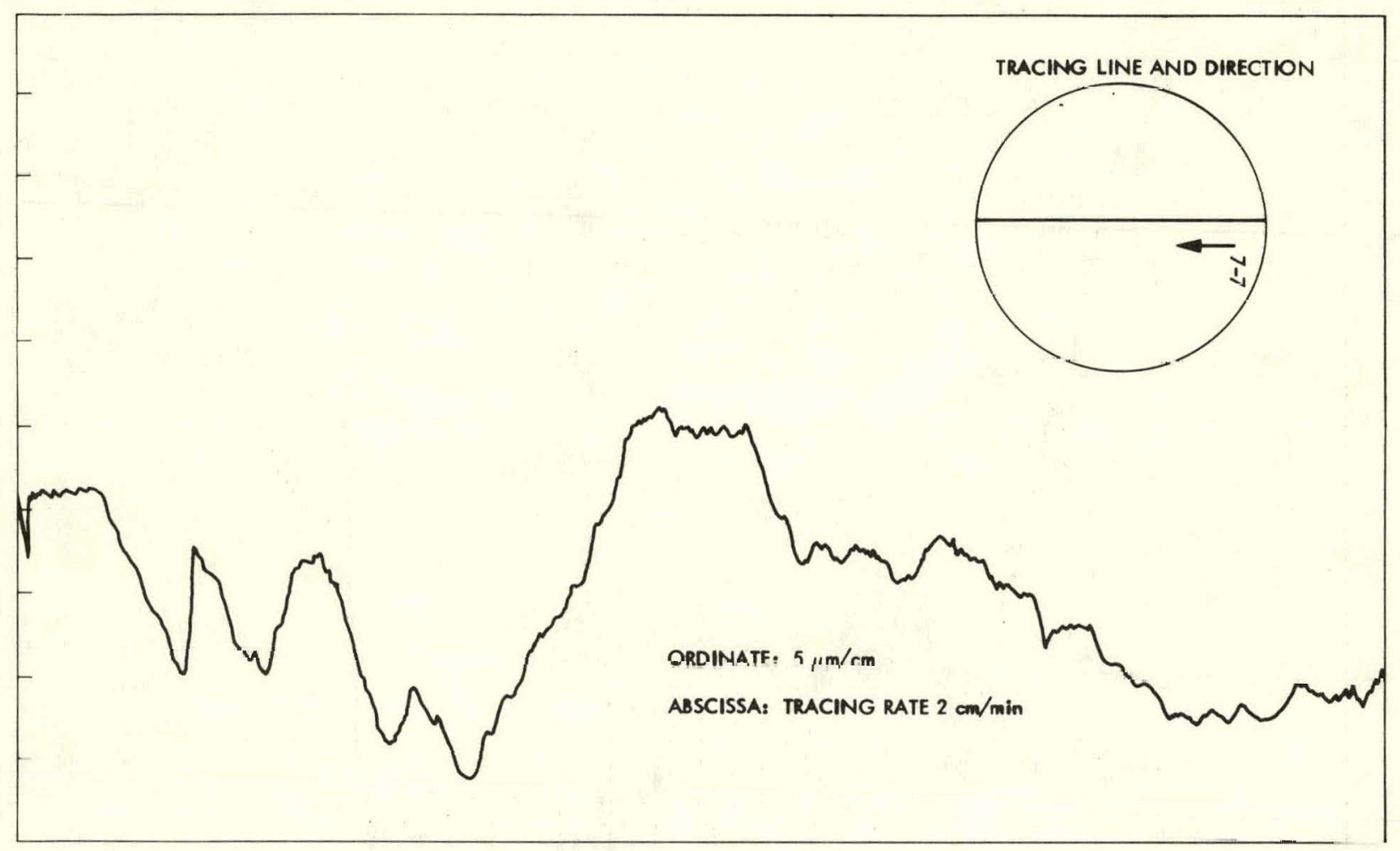

Figure 8. Macroscopic surface roughness of sample 7-7 measured by Dektak Tracer 


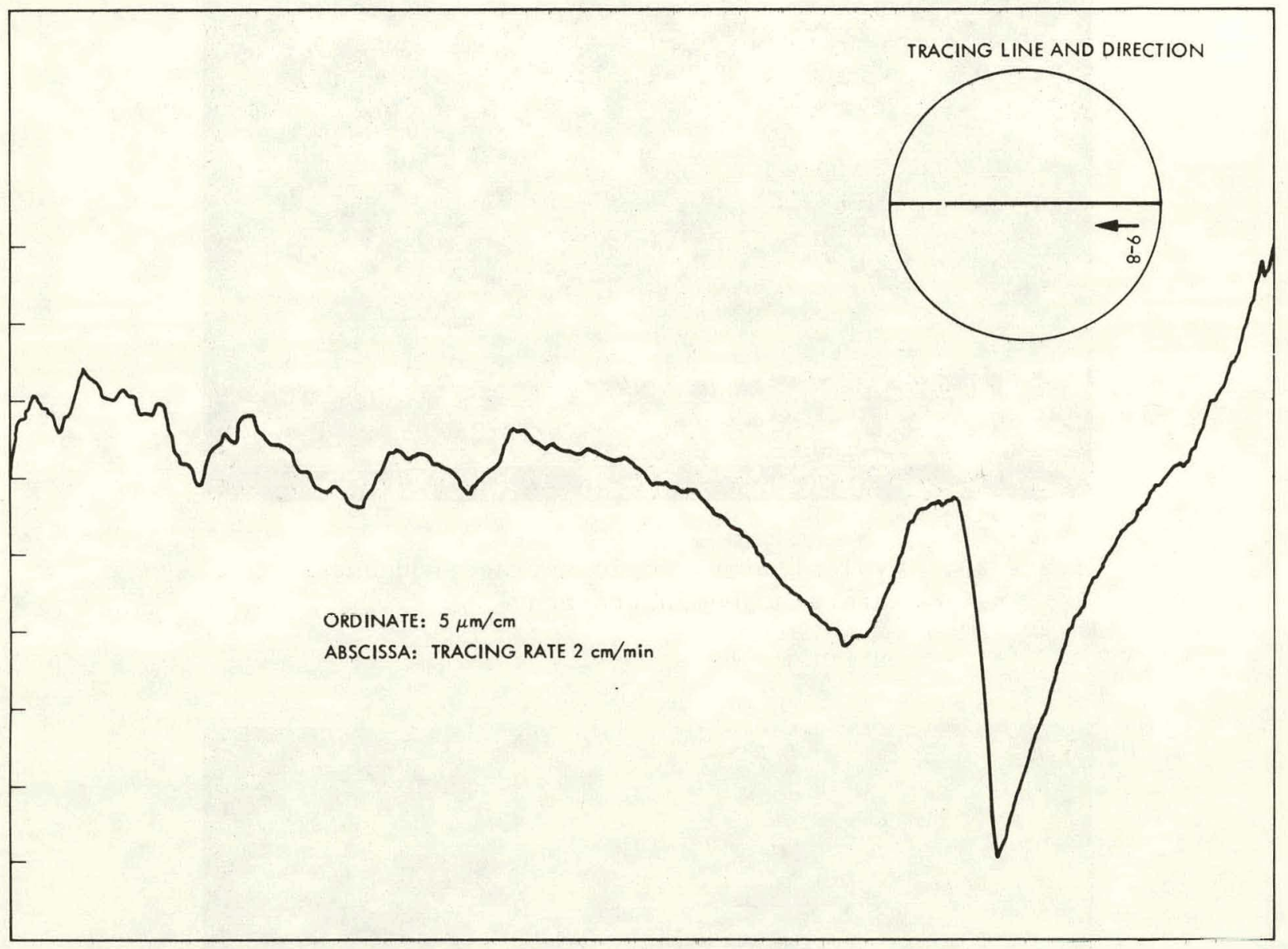

Figure 9. Macroscopic surface roughness of sample 9-8 measured by Dektak Tracer 


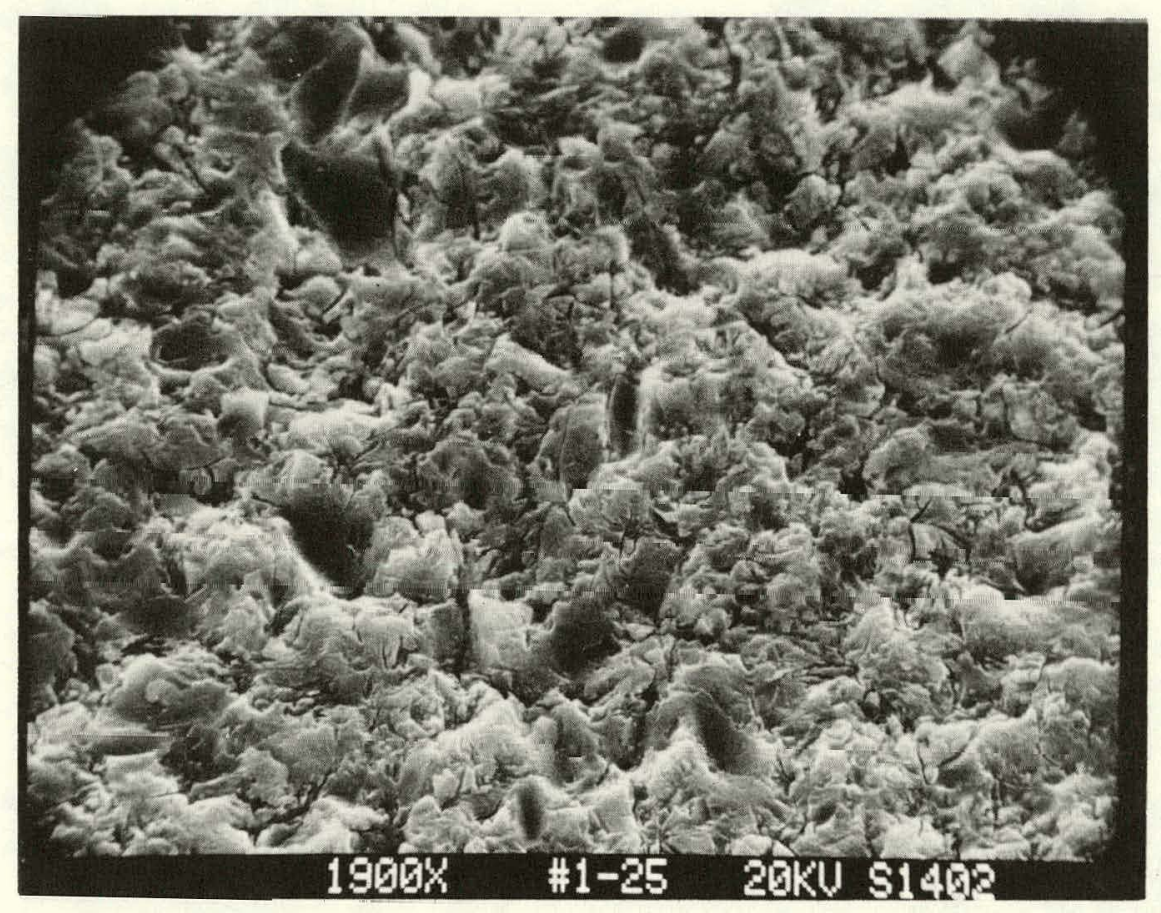

Figure 10. Typical microscopic surface roughness on the wafers of Demonstration 1

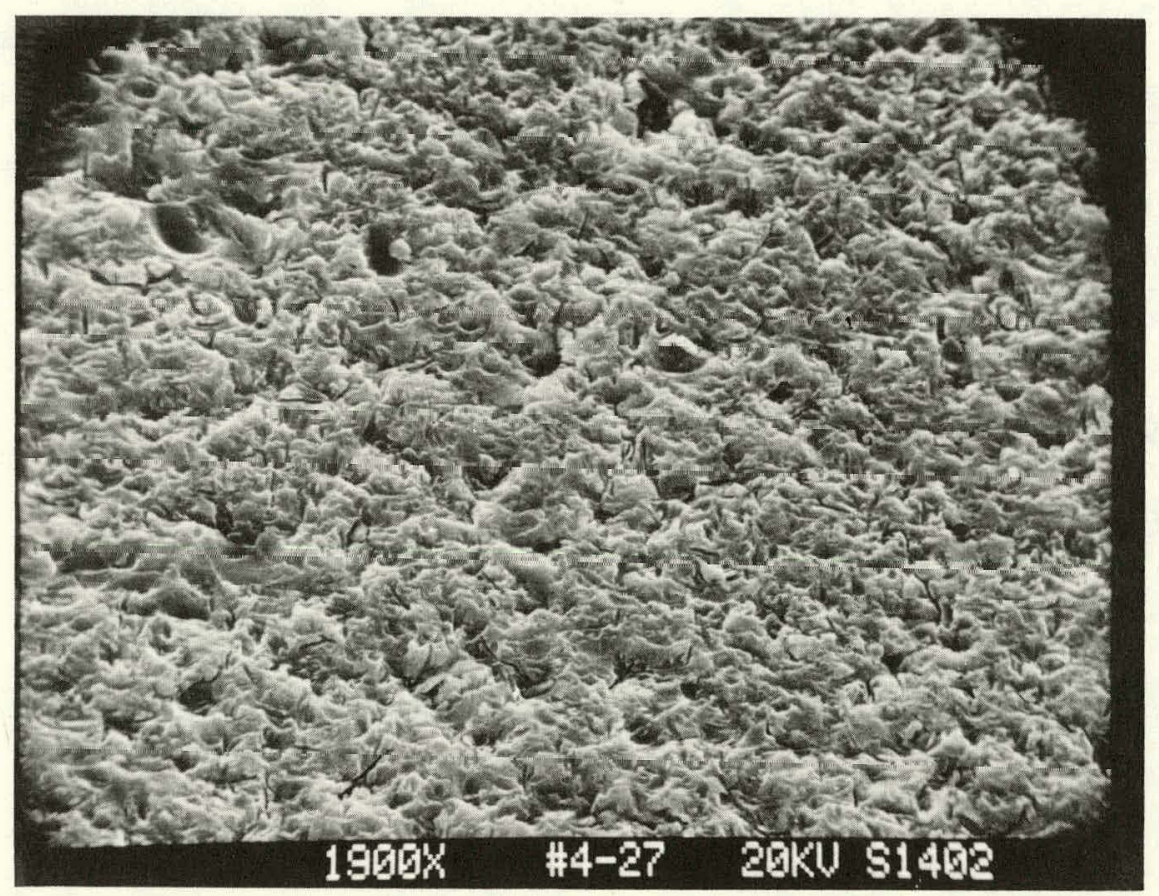

Figure 11. Typical microscopic surface roughness on the wafers of Demonstration 4 


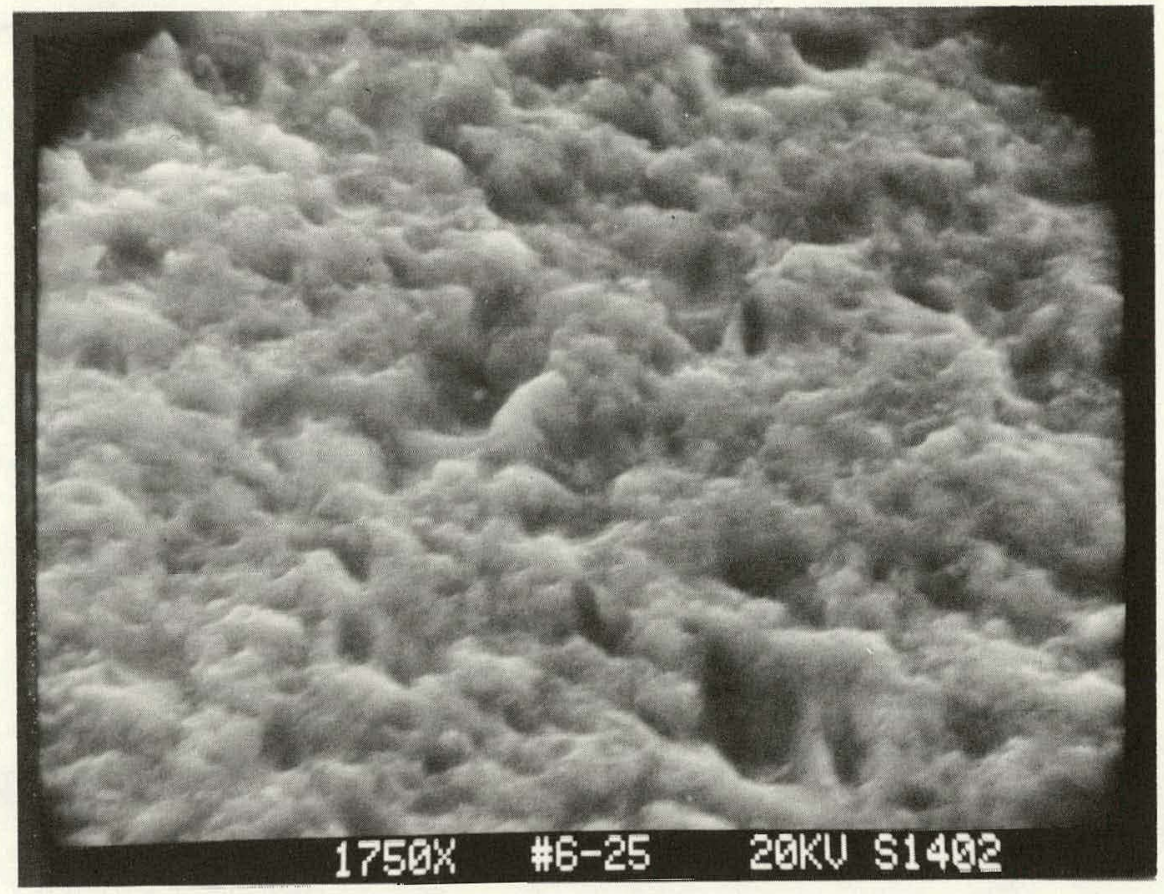

Figure 12. Typical microscopic surface roughness on the wafers of Demonstration 6 

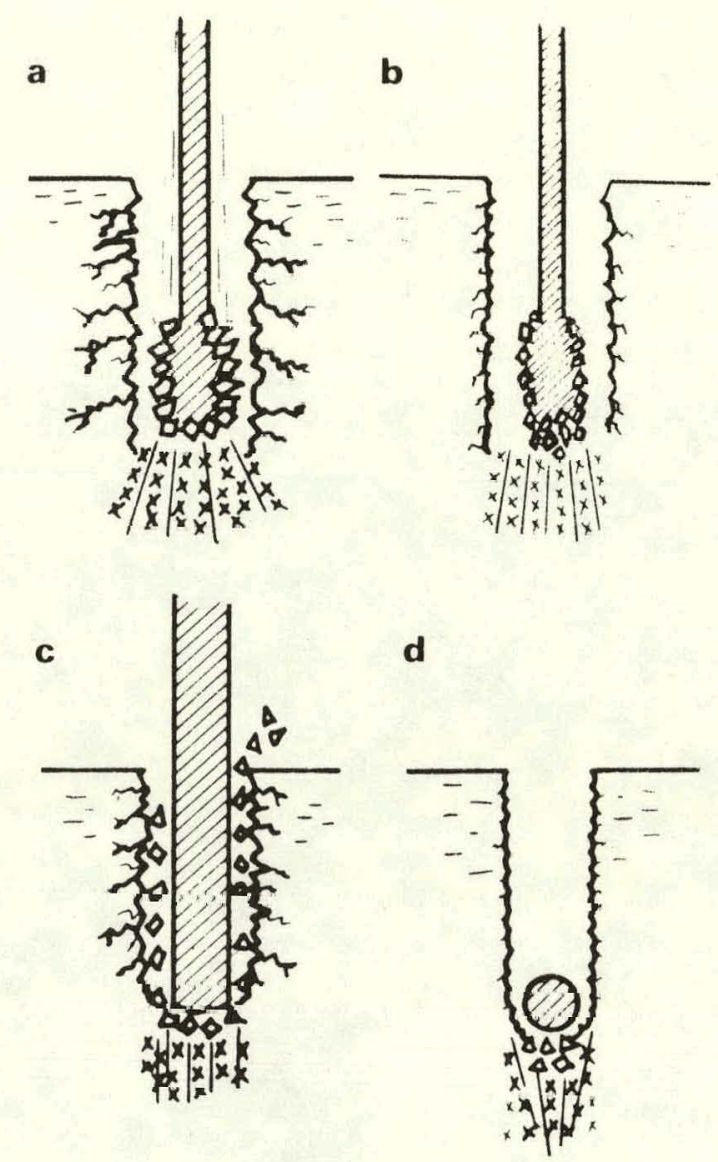

a Conventional O.D. saws grind on a spreading band from the parallel into the wafer surface. Excessive blade flutter further damages the crystal structure.

b. Properly conditioned I.D savws are stable and grind in a narrower band producing less than 12 micron sub-surface damage.

c. Band saws grind nearly parallel to the wafer surface, but the subsequent lapping action of the blade propagates

d. The YQ-100 Oscillating Wire Saw laps in the narrowest band, thereby generating very little crystal damage.

Figure 13. Schematic view of surface damage generation with saws 


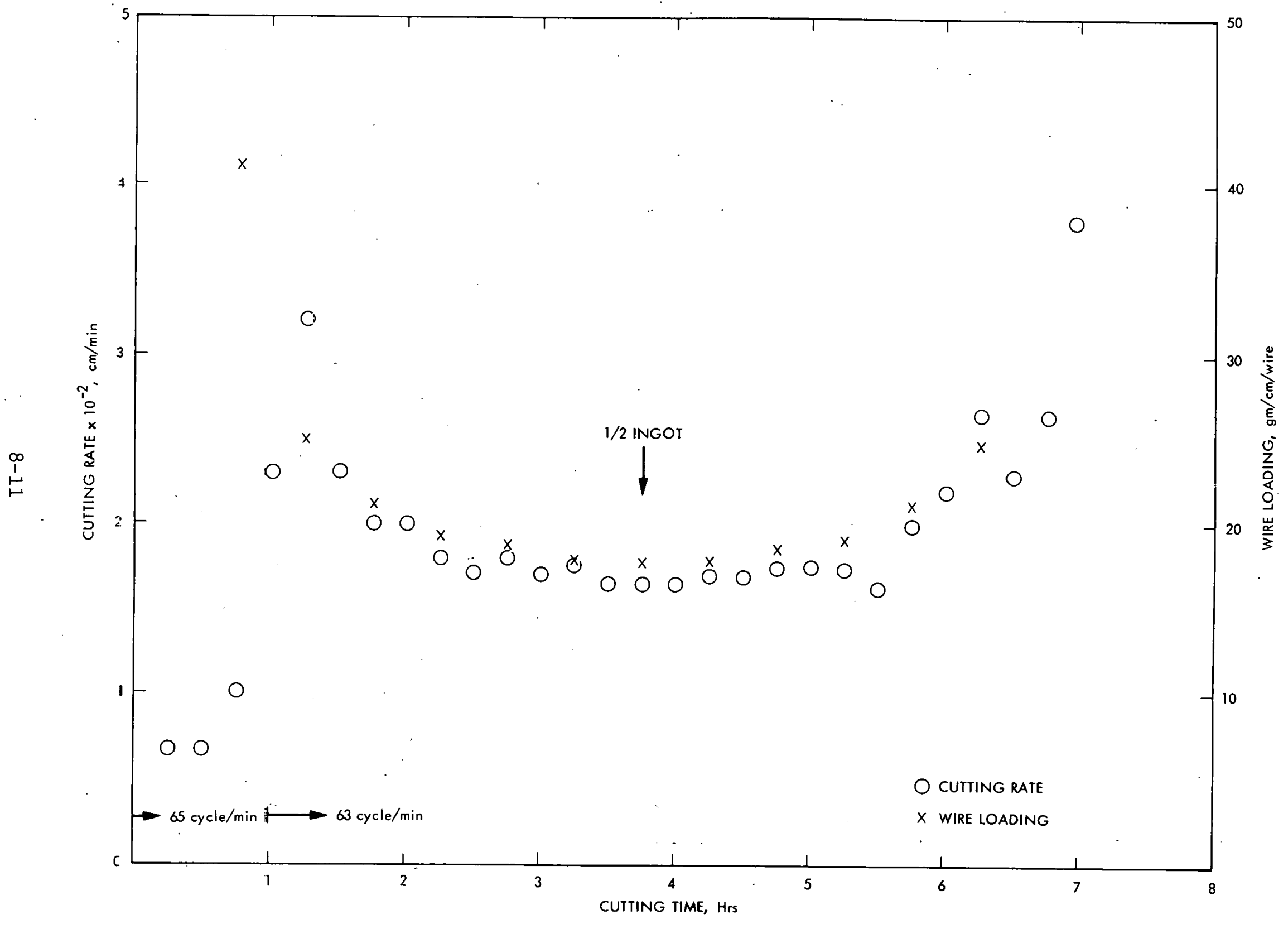

Figure 14. Cutting rate and wire loading vs cutting time of Demonstration 1 


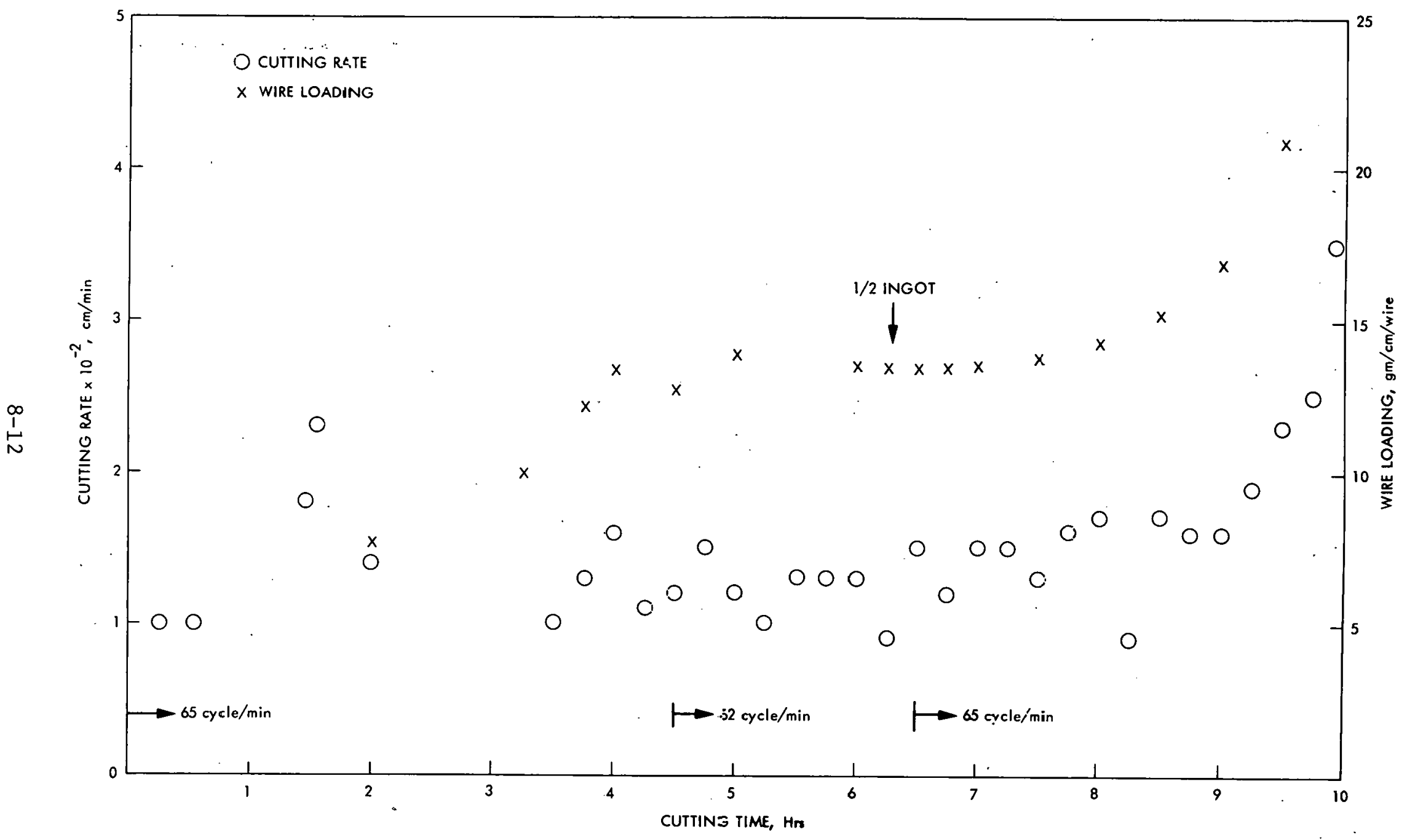

Figure 15. Cutting rate and wire loading vs cutting time oæ̃ Demonstration 2 


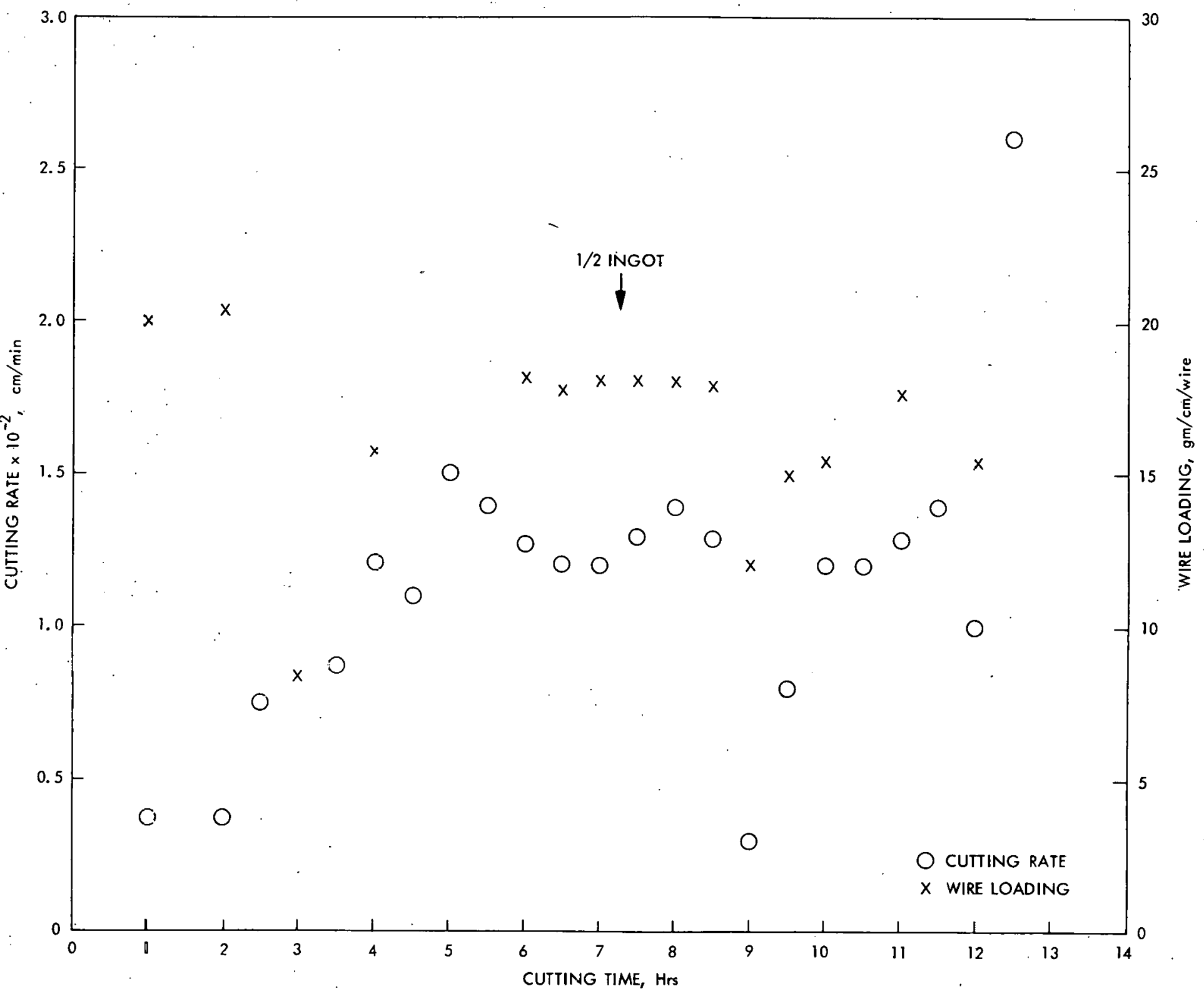

Figure 16. Cutting rate and wire loading vs cutting time of Demonstration 4 


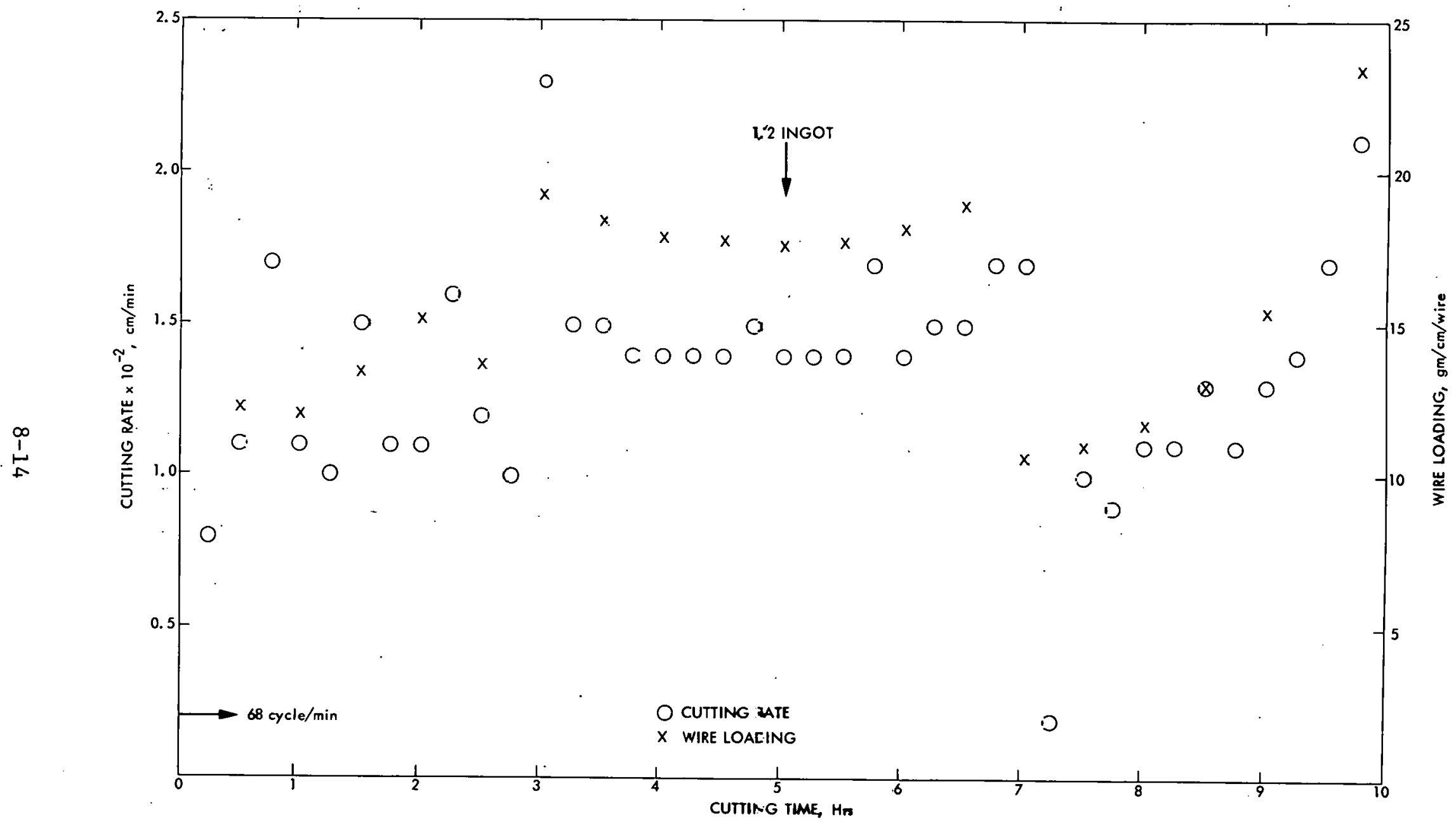

Figure 17: Cutting rate and wire loading vs cutting time of Demonstration 5 


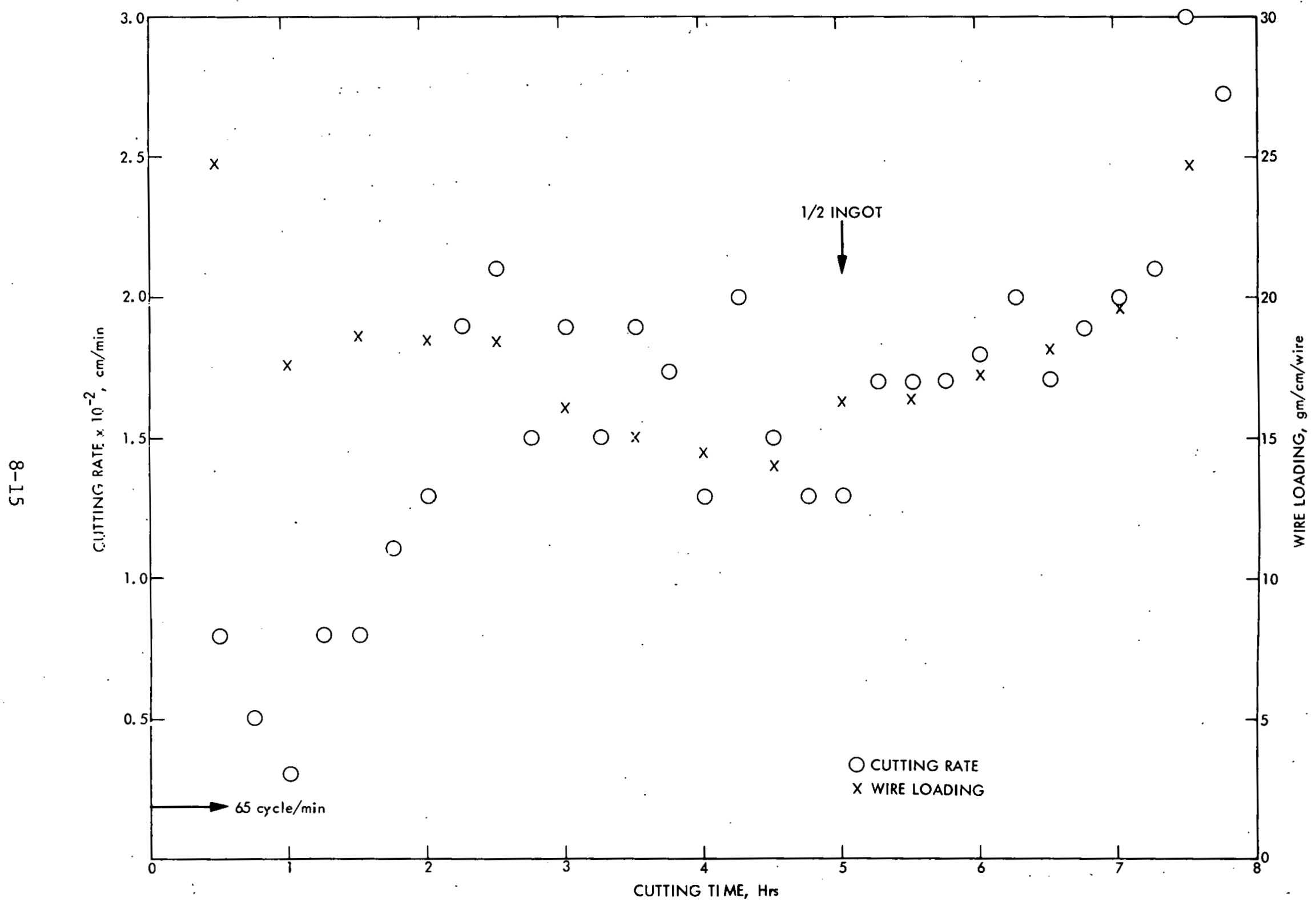

Figure 18. Cutting rate and wire loading vs cutting time of Demonstration 6 


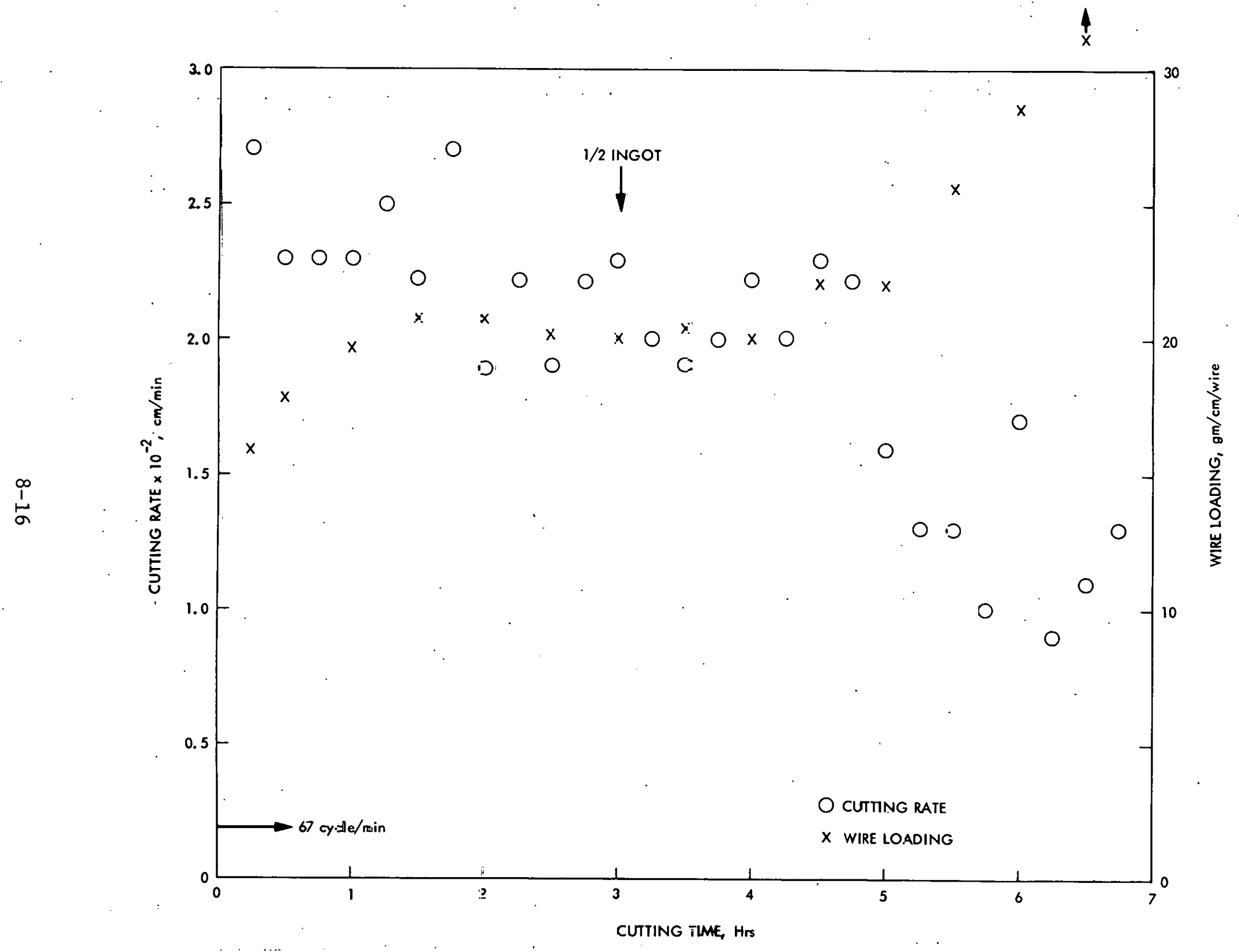

Figure 19. Cutting rate and wire loading vs cutting time of Demonstration 7 
Table 1. Specification of Yasunaga Multi-Wire Slurry Saw

Work Size

Simultaneous Cuts

Kerf. Thinness

Wafer Thinness

Accuracy

Wire Guide Pitch

Wire

Abrasive

Wire Stroke Length

Wire Stroke Rate

Wire Speed

Feeding Speed of new wire

Motors

Power Source

Air

Dimensions

Weight

Cutting Oil
$100 \times 100 \times 100 \mathrm{~mm}(4 \times 4 \times 4$ in.)

Up to 250 wafers or slots

Less than $0.1 \mathrm{~mm}(0.004 \mathrm{in.})$, using $0.08 \mathrm{~mm}$ wire and 5 um abrasive

Less than $0.15 \mathrm{~mm}(0.0006 \mathrm{in.})$

Thickness: Less than $\pm 5 \mu \mathrm{m}( \pm 0.0002 \mathrm{in.}) @ 75 \%$

Less than $\pm 10 \mu m( \pm 0.0004$ in. $) @ 3 \sigma$

Surface Finish: $2 \mu \mathrm{m}$ using $10 \mu \mathrm{m}$ abrasive

Parrallelism: $15 \mu \mathrm{m}(0.0006 \mathrm{in.})$ over $50 \mathrm{~mm}$ ( 2 in.)

Slot Depth: Less than $\pm 0.013 \mathrm{~mm}( \pm 0.0005 \mathrm{in.})$

$0.4,0.5,0.6,0.7,0.8,0.9,1.0,1.1 \mathrm{~mm}$ (custom pitches available).

Steel wire from 0.08 to $0.5 \mathrm{~mm}$ dia.

$\operatorname{SiC}: 5,9,12,15,20,30 \mu \mathrm{m}$

$700 \mathrm{~mm}$ one direction

30 to 80 cycles/min., variable

42 to $112 \mathrm{~m} / \mathrm{min}$. variable

0 to $15 \mathrm{~m} / \mathrm{min}$. variable

Main motor: $0.4 \mathrm{~kW}$ variable speed

Wire Feeding Motor: $0.1 \mathrm{~kW}$ variable speed

Abrasive Slurry Pump: $0.1 \mathrm{~kW}, 601 / \mathrm{min}$.

$208 \mathrm{~V}, 60 \mathrm{~Hz}, 3$ phase, $20 \mathrm{~A}$

$1.5 \mathrm{~kg} / \mathrm{Lu}^{2}, 1001 / \mathrm{mi}$.

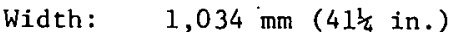

Depth: $1,125 \mathrm{~mm}$ (45 in.)

Height: $1,630 \mathrm{~mm}(64 \mathrm{in.})$

$1,400 \mathrm{~kg}(3,080 \mathrm{lbs})$

$3 \mu \mathrm{m}$ Lapping. Oil 
Table 2. Cutting conditions and result of Demonstration 1

\begin{tabular}{|c|c|c|}
\hline Variable Conditions & $\begin{array}{c}\text { JPL } \\
\text { Specified }\end{array}$ & Performed \\
\hline Roller Pitch, mm & 0.5 & 0.5 \\
\hline Wire size, in. & 0.005 & $0.0055(0.14 \mathrm{~mm})$ \\
\hline Abrasive size, $\mu \mathrm{m}$ & 9 & 10 \\
\hline Cutting Oil & Std & $\begin{array}{l}\text { Crane Lapping } \\
\text { Vehicle, } 3 \mathrm{M}\end{array}$ \\
\hline Slurry condition, abrasive/oil & New (Std) & New $(1, .67 / 1)$ \\
\hline No. s1ices & Std & 48 \\
\hline Wire tension, kg & Std & 1.5 \\
\hline Breaking Pt. of wire, $\mathrm{kg}$ & Std & 4.3 \\
\hline Wire feed rate, $\mathrm{m} / \mathrm{min}$ & 5 & 10 \\
\hline Wire cycle rate, cycle/min & 60 & 63 \\
\hline Wire load, kg & Std & $6.8 \max$ \\
\hline Unit wire load, $\mathrm{gm} / \mathrm{cm} /$ wire & - & 20 \\
\hline & \multicolumn{2}{|c|}{ Cutting Result } \\
\hline Total wire used, $\mathrm{m}$ & \multicolumn{2}{|r|}{4150} \\
\hline Total cutting time; hr:min & \multicolumn{2}{|r|}{$6: 55$} \\
\hline Ave. wafer thickness, $\begin{array}{l}\text { in. } \\
\mathrm{mm}\end{array}$ & \multicolumn{2}{|r|}{$\begin{array}{l}0.013 \\
0.339\end{array}$} \\
\hline Ave. kerf width, in. & \multicolumn{2}{|r|}{$\begin{array}{l}0.007 \\
0.17\end{array}$} \\
\hline Water yield, unbroken/total wafer. & \multicolumn{2}{|r|}{$47 / 48$} \\
\hline Wire wearing, $\mu \mathrm{m}$ & \multicolumn{2}{|r|}{6} \\
\hline Length of wire/cutting area, $\mathrm{m} / \mathrm{cm}^{2}$ & \multicolumn{2}{|r|}{1.75} \\
\hline
\end{tabular}


Table 3. Cutting conditions and result of Demonstration 2

\begin{tabular}{|c|c|c|}
\hline Variable Conditions & $\begin{array}{c}\text { JPL } \\
\text { Specified }\end{array}$ & Performed \\
\hline Roller Pitch, mm & 0.5 & 0.5 \\
\hline Wire size, in. & 0.004 & $0.0047(.12 \mathrm{~mm})$ \\
\hline Abrasive size, $\mu \mathrm{m}$ & 9 & 10 \\
\hline Cutting Oil & Std & $\begin{array}{l}\text { Crane Lapping } \\
\text { Vehicle } 3 \mathrm{M}\end{array}$ \\
\hline Slurry condition, abrasive/oil & $\begin{array}{l}\text { Reuse from } \\
\text { Demo. } 1\end{array}$ & New $(1.67 / 1)$ \\
\hline No. slices & Std & 47 \\
\hline Wire tension, kg & Std & 1.1 \\
\hline Breaking Pt. of wire, $\mathrm{kg}$ & Std & 3.2 \\
\hline Wire feed rate, $\mathrm{m} / \mathrm{min}$ & 5 & 10.3 \\
\hline Wire cycle rate, cycle/min & 60 & $62 \sim 65$ \\
\hline Wire load, kg & Std & $5 \max$ \\
\hline Unit wire load, $\mathrm{gm} / \mathrm{cm} /$ wire & - & 15 \\
\hline & \multicolumn{2}{|c|}{ Cutting Result } \\
\hline Total wire used, $\mathrm{m}$ & & 6130 \\
\hline Total cutting time, hr:min & & $9: 55$ \\
\hline $\begin{array}{r}\text { Ave, wafer thickness, in. } \\
\text { mm }\end{array}$ & & $\begin{array}{l}0.014 \\
0.367\end{array}$ \\
\hline $\begin{array}{l}\text { Ave. kerf width, in. } \\
\mathrm{mm}\end{array}$ & . & $\begin{array}{l}0.006 \\
0.15\end{array}$ \\
\hline Wafer yield, unbroken/total wafer & & $47 / 47$ \\
\hline Wire wearing,.$\mu \mathrm{m}$ & & 6 \\
\hline Length of wire/cutting area, $\mathrm{m} / \mathrm{cm}^{2}$ & & 2.67 \\
\hline
\end{tabular}


Table 4. Cutting conditions and result of Demonstration 3

\begin{tabular}{|c|c|c|}
\hline Variable Conditions & $\begin{array}{c}\text { JPL } \\
\text { Specified }\end{array}$ & Performed \\
\hline Roller Pitch, mm & 0.5 & 0.5 \\
\hline Wire size, in. & 0.004 & $0.0047(.12 \mathrm{~mm})$ \\
\hline Abrasive size, $\mu \mathrm{m}$ & 9 & 10 \\
\hline Cutting Oil & Std & $\begin{array}{l}\text { Crane Lapping } \\
\text { Vehicle } 3 \mathrm{M}\end{array}$ \\
\hline Slurry condition, abrasive/oil & New & $\begin{array}{l}\text { Reuse from } \\
\text { Demo. } 2+0.94 \mathrm{~kg} \\
\text { Abra. }+0.5 \mathrm{~kg} \\
\text { oil }\end{array}$ \\
\hline No. slices & Std & 44 \\
\hline Wire tension, $\mathrm{kg}$ & Std & 1.2 \\
\hline Breaking Pt. of wire, $\mathrm{kg}$ & Std & 3.2 \\
\hline Wire feed rate, $\mathrm{m} / \mathrm{min}$ & 5 & 10.5 \\
\hline Wire cycle rate, cycle/min & 60 & $65 \sim 68$ \\
\hline Wire Inad, $\mathrm{kg}$ & $\begin{array}{l}1-1 / 3 \mathrm{x} \\
\text { Demo. } 2\end{array}$ & $7.2 \log \operatorname{max.}$ \\
\hline Unit wire load, $\mathrm{gm} / \mathrm{cm} /$ wire & - & 2.3 .1 \\
\hline
\end{tabular}

- Cutting Result

Total wire used, $\mathrm{m}$

5050

Total cutting time, hr:min

$8: 25$

Ave. wafer thickness, in.

0.014

$\mathrm{mm}$

0.362

Ave. kerf width, in.

0.006

min

0.15

Wafer yield, unbroken/țotal wafer.

$42 / 44$

Wire wearing, $\mu \mathrm{m}$

9

Length of wire/cutting area, $\mathrm{m} / \mathrm{cm}^{2}$

2.35 
Table 5. Cutting conditions and result of Demonstration 4

\begin{tabular}{|c|c|c|}
\hline Variable Conditions & $\begin{array}{c}\text { JPL } \\
\text { Specified }\end{array}$ & Performed \\
\hline Roller Pitch, mm & 0.4 & 0.4 \\
\hline Wire size, in. & 0.003 & $0.0047(.12 \mathrm{~mm})$. \\
\hline Abrasive size, $\mu \mathrm{m}$ & 5 & $5(\# 3000)$ \\
\hline Cutting Oil & Std & $\begin{array}{l}\text { Crane Lapping } \\
\text { Vehicle } 3 \mathrm{M}\end{array}$ \\
\hline Slurry condition, abrasive/oil & New (Std) & New $(1 / 1.6)$ \\
\hline No. slices & Std & 54 \\
\hline Wire tension, $\mathrm{kg}$ & Std & 1.22 \\
\hline Breaking Pt. of wire, $\mathrm{kg}$ & Std & 3.2 \\
\hline Wire feed rate, $\mathrm{m} / \mathrm{min}$ & 7.5 & 12.0 \\
\hline Wire cycle rate, cycle/min & 60 & 68 \\
\hline Wire load, kg & Std & $7.6 \max$. \\
\hline Unit wire load, $\mathrm{gm} / \mathrm{cm} /$ wire & - & 20 \\
\hline \multicolumn{3}{|c|}{ Cutting Result } \\
\hline Total wire used, $\mathrm{m}$ & & 0 \\
\hline Total cutting time, hr:min & & \\
\hline $\begin{array}{l}\text { Ave. wafer thickness, in. } \\
\mathrm{mm}\end{array}$ & & \\
\hline Ave. kerf width, in. & & \\
\hline Wafer yield, unbroken/total wafer & & \\
\hline Wire wearing, $\mu \mathrm{m}$ & & \\
\hline Length of wire/cutting area, $\mathrm{m} / \mathrm{cm}^{2}$ & & 8 \\
\hline
\end{tabular}


Table 6. Cutting conditions and result of Demonstration 5

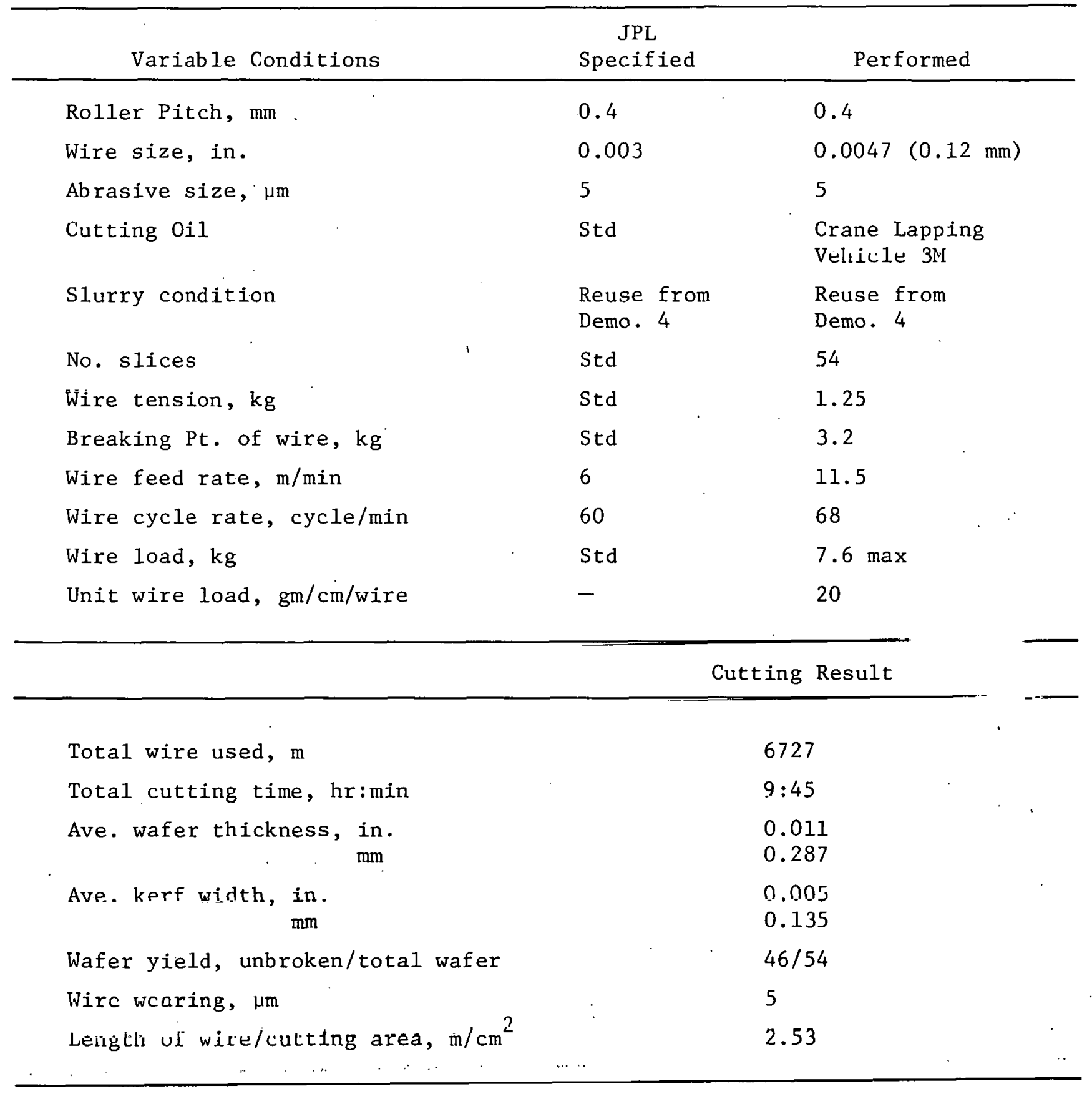


Table 7. Cutting conditions and result of Demonstration 6

\begin{tabular}{|c|c|c|}
\hline Variable Conditions & $\begin{array}{c}\text { JPL } \\
\text { Specified }\end{array}$ & Performed \\
\hline Roller Pitch, mm & 0.4 & 0.4 \\
\hline Wire size, in. & 0.003 & $0.0047(0.12 \mathrm{~mm})$ \\
\hline Abrasive size, $\mu \mathrm{m}$ & 9 & 10 \\
\hline Cutting $0 i 1$ & Std & $\begin{array}{l}\text { Crane Lapping } \\
\text { Vehicle } 3 \mathrm{M}\end{array}$ \\
\hline Slurry condition, abrasive/oil & New & New $(1.53 / 1)$ \\
\hline No. slices & Std & 54 \\
\hline Wire tension, $\mathrm{kg}$ & Std & 1.2 \\
\hline Breaking $\mathrm{Pt}$. of wire, $\mathrm{kg}$ & Std & 3.2 \\
\hline Wire feed rate, $\mathrm{m} / \mathrm{min}$ & 7.5 & 10 \\
\hline Wire cycle rate, cycle/min & 60 & 65 \\
\hline Wire 1oad, kg & Std & $7 \max$ \\
\hline Unit wire load, $\mathrm{gm} / \mathrm{cm} /$ wire & - & 18.4 \\
\hline \multicolumn{3}{|c|}{ Cutting Result } \\
\hline Total wire used, $\mathrm{m}$ & $\cdot$ & 4800 \\
\hline Total cutting time, hr:min & & $8: 0$ \\
\hline $\begin{array}{l}\text { Ave. wafer thickness, in. } \\
\text { mm }\end{array}$ & & $\begin{array}{l}0.011 \\
0.272\end{array}$ \\
\hline Ave, kerf wilth, $\begin{array}{l}\text { in. } \\
\mathrm{mm}\end{array}$ & & $\begin{array}{l}0.006 \\
0.15\end{array}$ \\
\hline Wafer yield, unbroken/total wafer. & & $51 / 54$ \\
\hline Wire wearing, $\mu \mathrm{m}$ & & 6 \\
\hline Length of wire/cutting area, $\mathrm{m} / \mathrm{cm}^{2}$ & & 1.83 \\
\hline
\end{tabular}


Table 8. Cutting conditions and result of Demonstration 7

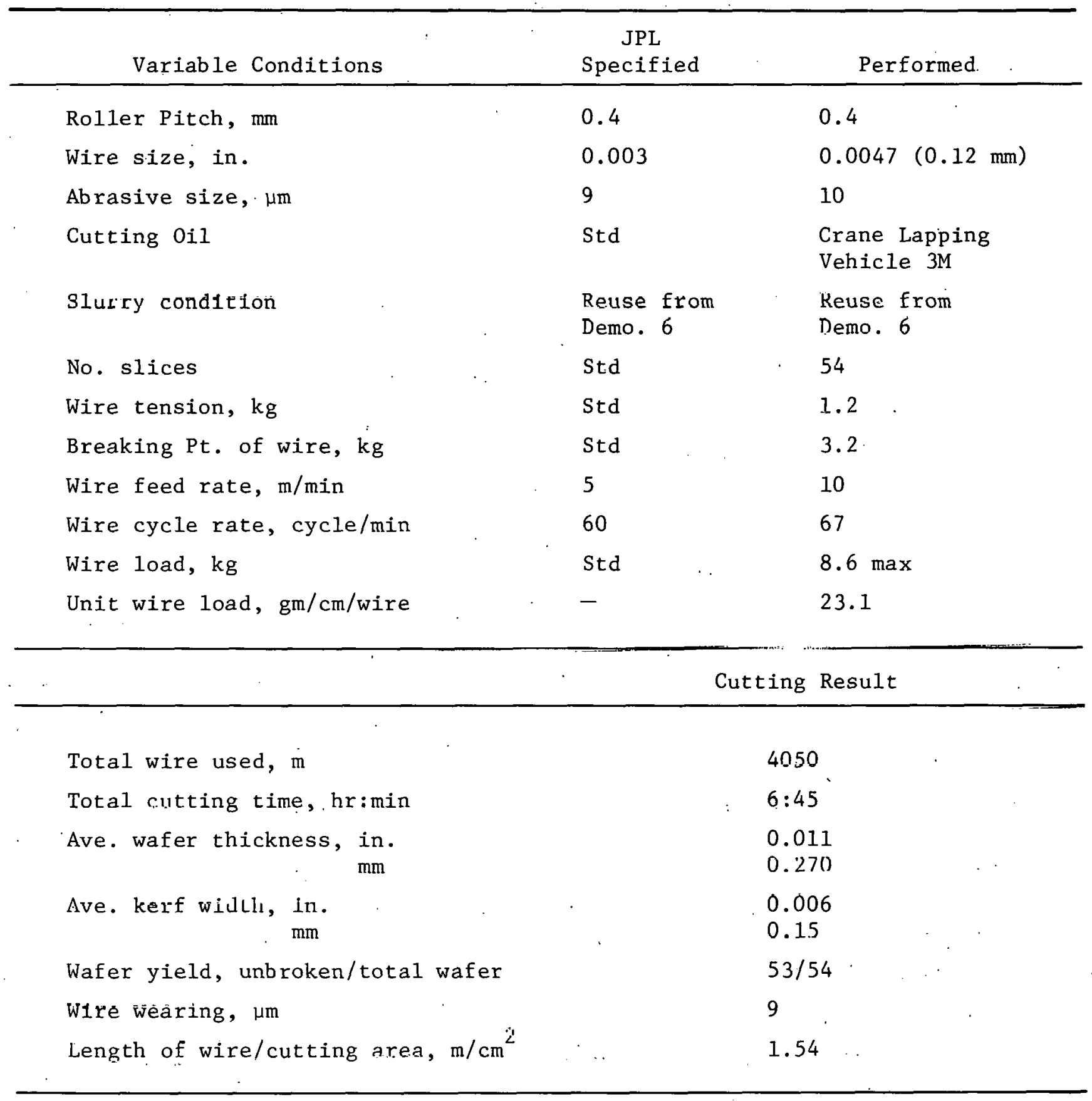


Table 9. Cutting conditions and result of Demonstration 8

\begin{tabular}{|c|c|c|}
\hline Variable Conditions & $\begin{array}{c}\text { JPL } \\
\text { Specified }\end{array}$ & Performed \\
\hline Roller Pitch, mm & 0.4 & 0.4 \\
\hline Wire size, in. & 0.003 & $0.0047(0.12 \mathrm{~mm})$ \\
\hline Abrasive size, $\mu \mathrm{m}$ & 9 & 10 \\
\hline Cutting Oil & Std & $\begin{array}{l}\text { Crane Lapping } \\
\text { Vehicle } 3 \mathrm{M}\end{array}$ \\
\hline Slurry condition & $\begin{array}{l}\text { Reuse from } \\
\text { Demo. } 7\end{array}$ & $\begin{array}{l}\text { Reuse from Demos. } 6 \\
\text { and } 7+1 \mathrm{~kg} \text { from } \\
\text { Demo. } 3\end{array}$ \\
\hline No. slices & Std & 60 \\
\hline Wire tension, $\mathrm{kg}$ & Std & 1.2 \\
\hline Breaking Pt. of wire, $\mathrm{kg}$ & Std & 3.2 \\
\hline Wire feed rate, $\mathrm{m} / \mathrm{min}$ & 5 & 10 \\
\hline Wire cycle rate, cycle/min & 60 & 67 \\
\hline Wire load, $\mathrm{kg}$ & std & $8.5 \max$ \\
\hline Unit wire load, $\mathrm{gm} / \mathrm{cm} /$ wire & - & 20.2 \\
\hline & \multicolumn{2}{|c|}{ Cutting Result } \\
\hline Total wire used, $\mathrm{m}$ & \multicolumn{2}{|r|}{$3870 *$} \\
\hline Total cutting time, hr:min & \multicolumn{2}{|r|}{$6: 27 *$} \\
\hline $\begin{array}{l}\text { Ave. wafer thickness, } \\
\text { in }\end{array}$ & \multicolumn{2}{|r|}{-} \\
\hline $\begin{array}{l}\text { Ave. kerf width, in. } \\
\text { mm }\end{array}$ & \multicolumn{2}{|r|}{-} \\
\hline Wafer yield, unbroken/total'wafer & \multicolumn{2}{|r|}{0} \\
\hline $\begin{array}{l}\text { Wire wearing, } \mu \mathrm{m} \\
\text { Length of wire/cutting area, } \mathrm{m} / \mathrm{cm}^{2}\end{array}$ & \multicolumn{2}{|r|}{-} \\
\hline
\end{tabular}

*Wafering failed because the wire broke at approximately 75 percent completion. 
Table 10. Cutting conditions and result of Demonstration 9

\begin{tabular}{|c|c|c|}
\hline Variable Conditions & $\begin{array}{c}\text { JPL } \\
\text { Specified }\end{array}$ & Performed \\
\hline Roller Pitch, mm & 0.4 & 0.4 \\
\hline Wire size, in. & 0.003 & $0.0047(0.12 \mathrm{~mm})$ \\
\hline Abrasive size, $\mu \mathrm{m}$ & 9 & 10 \\
\hline Cutting $\mathrm{Oil}$ & Std & $\begin{array}{l}\text { Crane Lapping } \\
\text { Vehicle } 3 \mathrm{M}\end{array}$ \\
\hline Slutiy condition & $\begin{array}{l}\text { Reuse from } \\
\text { Demo. } 8\end{array}$ & $\begin{array}{l}\text { Reuse from } \\
\text { Demos. } 6,1, \\
\text { and } 8\end{array}$ \\
\hline No. slices & Std & 49 \\
\hline Wire tension, $\mathrm{kg}$ & Std & 1.2 \\
\hline Breaking Pt. of wire, $\mathrm{kg}$ & Std & 3.2 \\
\hline Wire feed rate, $\mathrm{m} / \mathrm{min}$ & 4.5 & 10 \\
\hline Wire cycle rate, cycle/min & $\max$ & $65-67$ \\
\hline Wire load, $\mathrm{kg}$ & Std & $6.9 \max$ \\
\hline Unit wire load, $\mathrm{gm} / \mathrm{cm} /$ wire & - & 20 \\
\hline & \multicolumn{2}{|c|}{ Cutt1ng Result } \\
\hline Total wire used, $\mathrm{m}$ & & \\
\hline Total cutting time, hr:min & & 0 \\
\hline Ave. wafer thickness, in. & & $\begin{array}{l}11 \\
68\end{array}$ \\
\hline Ave. kerf width, in. & & 06 \\
\hline Wafer yield, unbroken/total wafer & $\cdots$ & \\
\hline Wire wenring, lim & & . \\
\hline Length of wire/cutting area, $\mathrm{m} / \mathrm{cm}^{2}$ & & . \\
\hline
\end{tabular}


Table 11. Cutting conditions and result of Demonstration 10

\begin{tabular}{|c|c|c|}
\hline Variable Conditions & $\begin{array}{c}\text { JPL } \\
\text { Specified }\end{array}$ & Performed \\
\hline Roller Pitch, mm & 0.4 & 0.4 \\
\hline Wire size, in. & 0.003 & $0.0039(0.10 \mathrm{~mm})$ \\
\hline Abrasive size, $\mu \mathrm{m}$ & 9 & 10 \\
\hline Cutting Oil & Std & $\begin{array}{l}\text { Crane Lapping } \\
\text { Vehicle } 3 M\end{array}$ \\
\hline Slurry condition & $\begin{array}{l}\text { Reuse from } \\
\text { Demo. } 9\end{array}$ & $\begin{array}{l}\text { Reuse from } \\
\text { Demos. } 6 \\
\text { through } 9\end{array}$ \\
\hline No. slices & Std & 55 \\
\hline Wire tension, $\mathrm{kg}$ & Std & 0.9 \\
\hline Breaking Pt. of wire, $\mathrm{kg}$ & Std & 2.2 \\
\hline Wire feed rate, $\mathrm{m} / \mathrm{min}$ & 4 & 10 \\
\hline Wire cycle rate, cycle/min & $\max$ & $40-65$ \\
\hline Wire load, kg & $\begin{array}{l}10 \% \text { less } \\
\text { Std }\end{array}$ & 3.0 \\
\hline Unit wire load, $\mathrm{gm} / \mathrm{cm} /$ wire & - & 7.8 \\
\hline & & Result \\
\hline Total wire used, $\mathrm{m}$ & \multicolumn{2}{|c|}{-} \\
\hline Total cutting time, hr:min & \multicolumn{2}{|c|}{$0: 13+1: 23^{*}$} \\
\hline Ave. wafer'thickness, in. & \multicolumn{2}{|c|}{$\begin{array}{l}0.010 \\
0.250\end{array}$} \\
\hline Ave. kerf width, in. & \multicolumn{2}{|c|}{$\begin{array}{l}0.005 \\
0.130\end{array}$} \\
\hline Wafer yield, unbroken/total wafer & \multicolumn{2}{|c|}{0} \\
\hline Wire wearing, $\mu \mathrm{m}$ & \multicolumn{2}{|c|}{-} \\
\hline Lenglh of wire/culling area, m/.um ${ }^{2}$ & \multicolumn{2}{|c|}{-} \\
\hline
\end{tabular}

*Wire broke after 13 minutes of slicing; rewire was made, wire broke after. $\mathrm{hr}$ and $23 \mathrm{~min}$ of restart. 
Table 12. Variables affecting economical silicon wafer production

\begin{tabular}{|c|c|c|c|c|}
\hline Variable & $\begin{array}{l}\text { Kerf } \\
\text { Width }\end{array}$ & $\begin{array}{l}\text { Cutting } \\
\text { Speed }\end{array}$ & $\begin{array}{l}\text { Surface } \\
\text { Quality }\end{array}$ & $\begin{array}{c}\text { Cutting } \\
\text { Costs }\end{array}$ \\
\hline Wire Size & $\mathrm{D}$ & D & $P$ & $\mathrm{D}$ \\
\hline Wire Composition & & $\mathrm{P}$ & $P$ & $\mathrm{D}$ \\
\hline Wire Coating (if any) & & $\mathrm{P}$ & $\mathrm{P}$ & $\mathrm{D}$ \\
\hline Wire Diameter Tolerance & & & $\mathrm{D}$ & $\mathrm{D}$ \\
\hline Wire Stroke Rate & $\mathrm{P}$ & $\mathrm{D}$ & $\mathrm{D}$ & $\mathrm{D}$ \\
\hline Wire Feed Rate & $\mathrm{D}$ & $\mathrm{P}$ & $P$ & $\mathrm{D}$ \\
\hline Abrasive Material. & $\mathrm{P}$ & $\mathrm{D}$ & $\mathrm{D}$ & $\mathrm{D}$ \\
\hline Abrasive Grit Size & $\mathrm{D}$ & $\mathrm{D}$ & $\mathrm{D}$ & $\mathrm{D}$ \\
\hline Abrasive Size Tolerance & $\mathrm{P}$ & $\mathrm{D}$ & $\mathrm{D}$ & $\mathrm{D}$ \\
\hline Abrasive Suspension Medium & $\mathrm{P}$ & $\mathrm{P}$ & $P$ & $\mathrm{D}$ \\
\hline Ratio of Abrasive to Suspendor & $P$ & $\mathrm{D}$ & $P$ & $\mathrm{D}$ \\
\hline Cutting Pressure & $\mathrm{P}$ & D & $\mathrm{D}$ & D \\
\hline Guide Roller Groove Pitch & & & & $\mathrm{D}$ \\
\hline $\begin{array}{l}\text { Guide Roller Material } \\
\text { (may affect minimum pitch) }\end{array}$ & . & & & D \\
\hline
\end{tabular}

D - Definite Effect

P - Pnssihle Effect 
Table 13. Summary of wafer and kerf thickness as function of the sizes of wire, abrasive and guide roller pitch

\begin{tabular}{|c|c|c|c|c|c|c|c|}
\hline Demo No. & $\begin{array}{c}\text { A } \\
\text { Wafer } \\
\text { Thickness, } \\
\text { mm }\end{array}$ & $\begin{array}{c}\text { B } \\
\text { Kerf } \\
\text { Thickness, } \\
\text { mm }\end{array}$ & $\begin{array}{c}\text { C } \\
\text { Wire } \\
\text { Size, } \\
\text { mm }\end{array}$ & $\begin{array}{c}D \\
\text { Abrasive } \\
\text { Size, } \\
\text { mm }\end{array}$ & $\begin{array}{c}\text { E } \\
\text { Roller } \\
\text { Pitch, } \\
\text { mm }\end{array}$ & $A+B$ & $B-C$ \\
\hline 1 & 0.339 & 0.17 & 0.14 & 0.010 & 0.5 & 0.509 & 0.03 \\
\hline 2 & 0.367 & 0.15 & 0.12 & 0.010 & 0.5 & 0.517 & 0.03 \\
\hline 3 & 0.362 & 0.15 & 0.12 & 0.010 & 0.5 & 0.512 & 0.03 \\
\hline 4 & $0.283^{\circ}$ & 0.135 & 0.12 & 0.005 & 0.4 & 0.418 & 0.015 \\
\hline 5 & 0.287 & 0.135 & 0.12 & 0.005 & 0.4 & 0.422 & 0.015 \\
\hline 6 & 0.272 & 0.15 & 0.12 & 0.010 & 0.4 & 0.422 & 0.03 \\
\hline 7 & 0.241 & 0.15 & 0.12 & 0.010 & 0.4 & 0.391 & 0.03 \\
\hline 9 & 0.268 & 0.15 & 0.12 & 0.010 & 0.4 & 0.418 & 0.03. \\
\hline 10 & 0.250 & 0.130 & 0.10 & 0.010 & 0.4 & 0.380 & 0.03 \\
\hline
\end{tabular}


Table 14. Average value of wafer thickness at the location of measurement, $\mathrm{mm}$

\begin{tabular}{ccccccc}
\hline & \multicolumn{7}{c}{ Location of Measurement** } & Maximum \\
\cline { 2 - 7 } Ingot No. & 1 & 2 & 3 & 4 & 5 & Variation, mm \\
\hline 1 & 0.346 & 0.336 & 0.335 & 0.339 & 0.339 & 0.011 \\
2 & 0.368 & 0.363 & 0.363 & 0.369 & 0.367 & 0.006 \\
3 & 0.360 & $*$ & $*$ & 0.363 & 0.362 & 0.003 \\
4 & 0.272 & $*$ & $*$ & 0.282 & 0.283 & 0.011 \\
5 & 0.269 & 0.284 & 0.274 & 0.274 & 0.287 & 0.018 \\
7 & 0.271 & $*$ & $*$ & 0.276 & 0.272 & 0.005 \\
9 & 0.267 & $*$ & $*$ & 0.243 & 0.241 & 0.025 \\
\hline
\end{tabular}

*No significant change from 5 .

**Location of measurement on a wafer is shown in Figure 3.

Table 15. Microscopic surface roughness and damage of scveral samples sliced by the mult1-wire-slurry saw

\begin{tabular}{ccc} 
Specimen No. & Roughness, $\mu \mathrm{m}^{*}$ & Damage Depth, $\mu \mathrm{m}^{* * *}$ \\
\hline $1-25$ & $\sim 5$ & 10 \\
$4-27$ & $\sim 3$ & 6.5 \\
$5-27$ & $\sim 3$ & 6.5 \\
$6-2.5$ & $\sim 6$ & 7.2 \\
$9-25$ & $\cdot 5$ & 8.5 \\
\hline
\end{tabular}

*Average irregularity spacing observed on wafer surfare by SEM.

**Optical microscopic examination on the angle lapped and Sirtl-etched wafer surface. 
Table 16. Summary of cutting rate ( $\mu \mathrm{m} / \mathrm{min}$. per $\mathrm{gm}$ of each $\mathrm{cm}$ of wire load) of several slicing demonstrations

\begin{tabular}{cccccc}
\hline $\begin{array}{c}\text { Slicing } \\
\text { No. }\end{array}$ & $\begin{array}{c}\text { Abrasive } \\
\text { Size, } \\
\mu \mathrm{m}\end{array}$ & $\begin{array}{c}\text { Wire } \\
\text { Size, } \\
\mathrm{mm}\end{array}$ & $\begin{array}{c}\text { No. Reuse } \\
\text { of } \\
\text { Slurry }\end{array}$ & $\begin{array}{c}\text { Cutting Rate, } \\
\mu \mathrm{m} / \mathrm{min} / \mathrm{gm} / \mathrm{cm} / \text { wire }\end{array}$ & $\begin{array}{c}\text { Total } \\
\text { S1icing Time, } \\
\text { hr-min }\end{array}$ \\
\hline 1 & 10 & 0.14 & 0 & 9.6 & $6-55$ \\
2 & 10 & 0.12 & 0 & 9.6 & $9-55$ \\
4 & 5 & 0.12 & 0 & 6.9 & $12-30$ \\
5 & 5 & 0.12 & 1 & 7.9 & $9-45$ \\
6 & 10 & 0.12 & 0 & 10.0 & $8-0$ \\
7 & 10 & 0.12 & 1 & 11.0 & $6-45$ \\
\hline
\end{tabular}

Table 17. Steel. wire prices

\begin{tabular}{cccc}
\hline Wire Size, in. & Appro. Meter $/ \mathrm{kg}$ & $\$ / \mathrm{kg}$ & $\$ / \mathrm{m}$ \\
\hline 0.003 & 28,000 & 115.00 & $4.1 \times 10^{-3}$ \\
0.004 & 16,000 & 71.00 & $4.44 \times 10^{-3}$ \\
0.005 & 10,000 & 57.00 & $5.70 \times 10^{-3}$ \\
0.006 & 7,000 & 40.00 & $5.70 \times 10^{-3}$ \\
0.007 & 5,000 & 28.00 & $5.6 \times 10^{-3}$ \\
\hline
\end{tabular}


Table 18. Milasil silicon carbide abrasive prices

\begin{tabular}{cc}
\hline $\mathrm{m}$ Size & Price per 5 1bs. \\
\hline 5 & $\$ 45.00$ \\
9 & 37.50 \\
12 & 27.50 \\
15 & 22.75 \\
20 & 19.50 \\
30 & 18.25 \\
\hline
\end{tabular}

Table 19. Prices of rollers

\begin{tabular}{lc}
\hline $\begin{array}{l}\text { Grooved guide roller, } \\
\text { standard pitch }\end{array}$ & $\$ 91.25 /$ set \\
Regrooving of guide roller & $\$ 60.00 /$ set \\
Idler roller & $\$ 20.50 /$ set \\
V-ruller & $\$ 1$ bu.5u/set \\
\hline
\end{tabular}


Table 20. Cost of wire, abrasive and rollers for the demonstrations

\begin{tabular}{|c|c|c|c|c|c|c|}
\hline \multirow[b]{2}{*}{ Demonstration } & \multirow[b]{2}{*}{ Wire, $\$ / \mathrm{m}^{2}$} & \multirow{2}{*}{\multicolumn{2}{|c|}{ Abrasive, Total }} & \multicolumn{3}{|c|}{ Roller } \\
\hline & & & $\$$ & $\begin{array}{l}\text { Guide, } \\
\text { Total \$ }\end{array}$ & $\begin{array}{l}\text { Idler, } \\
\text { Total \$ }\end{array}$ & $\begin{array}{c}\mathrm{V}, \\
\text { Total }\end{array}$ \\
\hline 1 & 99.75 & 82.50 & & 91.25 & 20.50 & 150.50 \\
\hline 2 & 152.20 & 82.50 & & - & - & - \\
\hline 3 & 104.35 & 16.50 & & - & - & - \\
\hline 4 & 150.10 & 89.30 & & 91.25 & 20.50 & - \\
\hline 5 & 112.33 & - & . & - & - & - \\
\hline 6 & 81.25 & 86.00 & & - & - & - \\
\hline 7 & 68.40 & - & & - & - & - \\
\hline 8 & * & - & & - & - & - \\
\hline 9 & 98.60 & - & & - & - & - \\
\hline 10 & * & - & & - & - & - \\
\hline
\end{tabular}

*Failed to complete

-Reuse from previous demonstration 


\section{APPENDIX A \\ CUTTING DATA FOR JPL'S \\ SILICON INGOT}
(1) Data Sheet for Cutting Condition
(2) Time-Vertical Position Data Sheet
(3) Slice Thickness Data Sheet

Yasunaga Engineering Co., Ltd.

14 November 1977 


\section{THIS PAGE}

\section{WAS INTENTIONALLY \\ LEFT BLANK}




\section{SAMPLE CUTTING DATA SHEET \\ DEMONSTRATION 1 \\ 2 Nov. 1977}

\section{Specification of Prospect}

1. Materials of workpiece

Silicon

2. Dimension of work

3. Machine No.

4. Cartridge type

5. Hour put to used of head rollers

ф $78 \times 28.2 \mathrm{~mm}$

YQ-100 \#143

"G"

$0 \mathrm{hr}, 0 \mathrm{~min}$

Cutting Condition

1. Roller pitch

2. Diameter of wire

3. Abrasive

4. Lapping oil

5. Ratio of 3 to 4

6. Bond

7. Mean amount of kerf

8. No. of wire under cutting

9. Total weight

10. Mean unit weight

11. Total wire tension

12. Breaking point of wire

13. Feeding amount of wire

14. Reciprocation of wire

15. Wears of wire

16. Total length of used wire

$0.5 \mathrm{~mm}$

$0.14 \mathrm{~mm}$

New GC \#1500 (10 $\mu \mathrm{m}) 5 \mathrm{~kg}$

New $3 \mathrm{~kg}$

$1.67: 1$

Sunlock SMD-01

$0.17 \mathrm{~mm}$

49

Max $6.8 \mathrm{~kg}$

Max $20 \mathrm{~g} / \mathrm{cm} /$ wire

$1.5 \mathrm{~kg}$

$4.3 \mathrm{~kg}$

$10 \mathrm{~m} / \mathrm{min}$

$63 \mathrm{cycle} / \mathrm{min}$

$6 \mu \mathrm{m}$

$4150 \mathrm{~m}$

Working Efficiency

1. Total working time

$6 \mathrm{hr}, 55 \mathrm{~min}$

2. Number of works

48 pcs

3. Working time of unit work

$8.4 \mathrm{~min}$

4. Total cutting area

$2371 \mathrm{~cm}^{2}$

5. Total volumes of kerf

$40.3 \mathrm{~cm}^{3}$

6. Mean volumes of kerf

$0.097 \mathrm{~cm}^{3} / \mathrm{min}$

\section{Schematics of Work Installed}

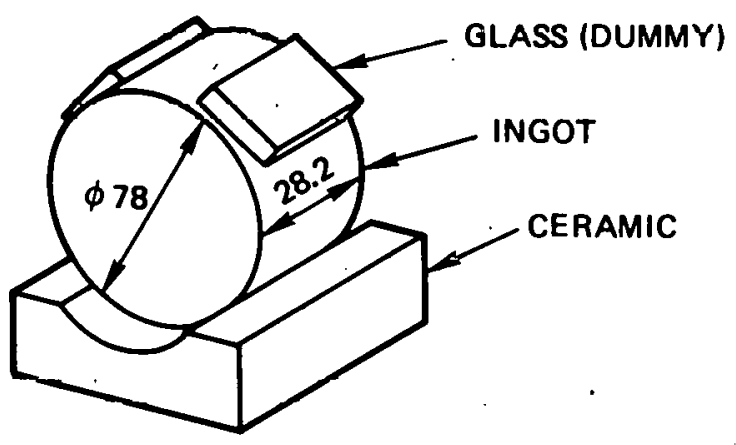




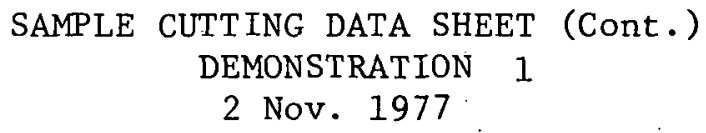

\section{Remarks}

1. It was 40 minutes from the time the machine started to the silicon cutting in (this time is required to cut dummy glass), and so this time was subtracted from the actual time.

\section{Note: same hereafter}

2. At cutting in of silicon ingot, total weight was $5.1 \mathrm{~kg}$; at 45 minutes after this, total weight was $6.6 \mathrm{~kg}$; at 5 minutes later, total weight was $6.8 \mathrm{~kg}$.

3. The beginning cycle rate was 65 cycles/min, but we dropped down to 63 cycles/ min after 85 minutes (from when wire was cutting in sili.con ingnt) because the operator side's wire was delaying. 
TIME-VERTICAL POSITION DATA SHEET

DEMONSTRATION $\cdot 1$

2 Nov: 1977

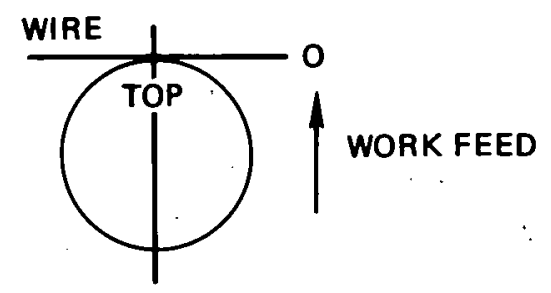

\begin{tabular}{|c|c|c|c|c|c|c|c|c|}
\hline $\begin{array}{l}\text { Time, } \\
\text { Hr-Min }\end{array}$ & $\begin{array}{c}\text { Vert.: } \\
\text { Pos., } \\
\text { mm }\end{array}$ & $\begin{array}{c}\text { Total } \\
\text { Weight, } \\
\text { kg }\end{array}$ & $\begin{array}{c}\text { Cycle/ } \\
\text { Min }\end{array}$ & & $\begin{array}{l}\text { Time, } \\
\text { Hr-Min }\end{array}$ & $\begin{array}{c}\text { Vert. } \\
\text { Pos., } \\
\text { mm }\end{array}$ & $\begin{array}{c}\text { Total } \\
\text { Weight, } \\
\text { kg }\end{array}$ & $\begin{array}{c}\text { Cycle/ } \\
\text { Min }\end{array}$ \\
\hline 00 & 0 & 5.1 & 65 & & $5-00$ & 51.7 & 6.8 & 63 \\
\hline 15 & 1.0 & 5.1 & 65 & & 15 & 54.3 & 6.8 & 63 \\
\hline 30 & 2.0 & 5.1 & 65 & & 30 & 56.7 & 6.8 & 63 \\
\hline 45 & 3.5 & 6.6 & 65 & & 45 & 59.7 & 6.8 & 63 \\
\hline $1-00$ & 7.0 & 6.8 & 63 & & $6-00$ & 63.0 & 6.8 & 63 \\
\hline 15 & 11.8 & 6.8 & 63 & & 15 & 67.0 & 6.8 & 63 \\
\hline 30 & 15.2 & 6.8 & 63 & & 30 & 70.5 & 6.8 & 63 \\
\hline 45 & 18.2 & 6.8 & 63 & & 45 & 74.5 & 6.8 & 63 \\
\hline $2-00$ & 21.3 & 6.8 & 63 & & 55 & 78.5 & 6.8 & 63 \\
\hline 1.5 & 24.0 & 6.8 & 63 & & & & & \\
\hline 30 & 26.5 & 6.8 & 63 & & & & & \\
\hline 45 & 29.2 & 6.8 & 63 & & & & & \\
\hline $3-00$ & 31.7 & 6.8 & 63 & & & & & \\
\hline 15 & 34.3 & 6.8 & 63 & & & & & \\
\hline 30 & 36.7 & 6.8 & 63 & & & & & \\
\hline 45 & 39.1 & 6.8 & 63 & & & & & \\
\hline $4-00$ & 41.5 & 6.8 & 63 & & $:$ & & & \\
\hline 15 & 44.0 & 6.8 & 63 & & & & & \\
\hline 30 & 46.5 & 6.8 & 63 & & & & & \\
\hline 45 & 49.1 & 6.8 & 63 & & & & & \\
\hline
\end{tabular}




\section{SLICE THICKNESS DATA SHEET}

DEMONSTRATION 1

2 Nov. 1977
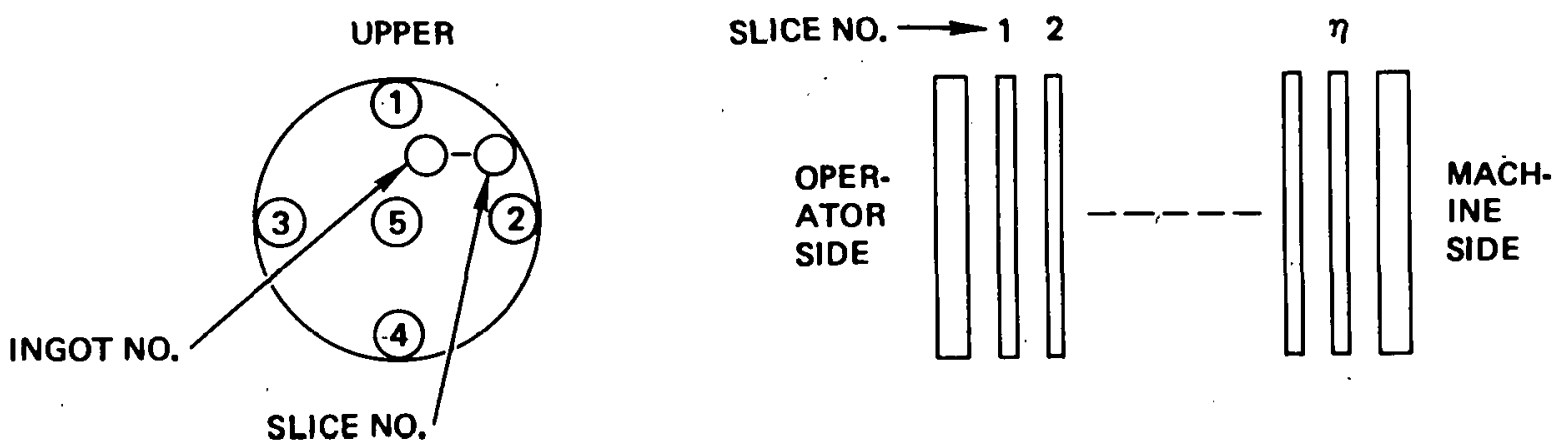

SLICE NO.

\begin{tabular}{|c|c|c|c|c|c|}
\hline Slice No. & $(1)$ & (2) & $\underbrace{3}_{\mathrm{mm}}$ & $\underbrace{4}_{\mathrm{mm}}$ & $\underbrace{}_{\mathrm{mm}}$ \\
\hline 2 & 0.354 & 0.310 & 0.310 & 0.294 & 0.315 \\
\hline 5 & 0.354 & 0.345 & 0.346 & 0.361 & 0.349 \\
\hline 10 & 0.332 & 0.335 & 0.329 & 0.325 & 0.334 \\
\hline 15 & 0.347 & 0.342 & 0.339 & 0.359 & 0.343 \\
\hline 20 & 0.348 & 0.344 & 0.345 & 0.352 & 0.348 \\
\hline 25 & 0.337 & 0.326 & 0.327 & 0.324 & 0.327 \\
\hline 30 & 0.341 & 0.334 & 0.331 & 0.345 & 0.333 .3 \\
\hline 35 & 0.347 & 0.337 & 0.338 & 0.335 & 0.341 \\
\hline 40 & 0.360 & 0.342 & 0.341 & 0.340 & 0.349 \\
\hline 45 & 0.344 & 0.345 & 0.344 & 0.353 & 0.348 \\
\hline
\end{tabular}




\section{SAMPLE CUITING DATA SHEET}

DEMONSTKATION 2

3 Nov. 1977

Specification of Prospect

1. Materials of workpiece

Silicon

2. Dimension of work

3. Machine No.

4. Cartridge type

5. Hour put to used of head rollers.

$\phi 78 \times 29.5 \mathrm{~mm}$

YQ-100 \#143

"G"

$6 \mathrm{hr}, 55 \mathrm{~min}$

\section{Cutting Condition}

1. Roller pitch

2. Diameter of wire

3. Abrasive

4. Lapping oil

5. Ratio of 3 to 4

6. Bond

7. Mean amount of kerf

8. No. of wire under cutting

9. Total weight

10. Mean unit weight

11. Total wire tension

12. Breaking point of wire

13. Feeding amount of wire

14. Reciprocation of wire.

15. Wears of wire

16. Total length of used wire

Working Efficiency

1. Total working time

2. Number of works

3. Working time of unit work

4. Total cutting area

5. Total volumes of kerf

6. Mean volumes of kerf

\section{Schematics of Work Installed}

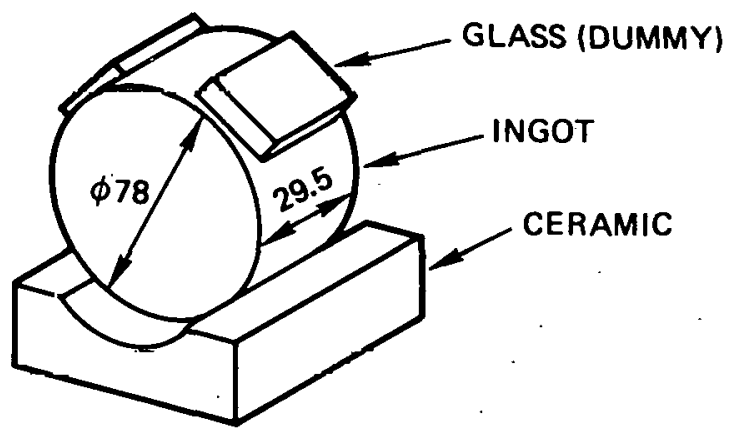

$0.5 \mathrm{~mm}$

$0.12 \mathrm{~mm}$

New GC \#1500 $(10 \mu \mathrm{m}) 5 \mathrm{~kg}$

New $3 \mathrm{~kg}$

$1.67: 1$

Sunlock SMD-01

$0.15 \mathrm{~mm}$

48

$\operatorname{Max} 5 \mathrm{~kg}$

Max $15 \mathrm{~g} / \mathrm{cm} /$ wire

$1.1 \mathrm{~kg}$

$3.2 \mathrm{~kg}$

$10.3 \mathrm{~m} / \mathrm{min}$

$62 \sim 65$ cycle/min

$6 \mu \mathrm{m}$

$6130 \mathrm{~m}$

$9 \mathrm{hr}, 55 \mathrm{~min}$

47 pcs

12.6 min

$2293.6 \mathrm{~cm}^{2}$

$34.4 \mathrm{~cm}^{3}$

$0.058 \mathrm{~cm}^{3} / \mathrm{min}$ 


\section{SAMPLE CUTTING DATA SHEET (Cont.) \\ DEMONSTRATION 2}

3 Nov. 1977

\section{Remarks}

1. Abrasive slurry for No. 2 ingot was instructed to be the same as for No. 1 ingot by GEOS. In cutting No. 1 ingot, some amount of abrasive slurry was leaked from pipe fitting of oil pump, so abrasive slurry volume became below one-half, and new abrasive slurry was used for this operation.

2. Cannot load normal total veight because operator side's wire was delayed by that wirc tension being lisw.

3. Used some part of 3 roller set the same as for No. 1 ingot. 


\section{TIME-VERTICAL POSITION DATA SHEET}

DEMONSTRATION 2

3 Nov. 1977

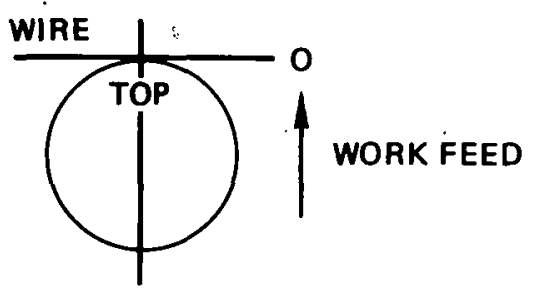

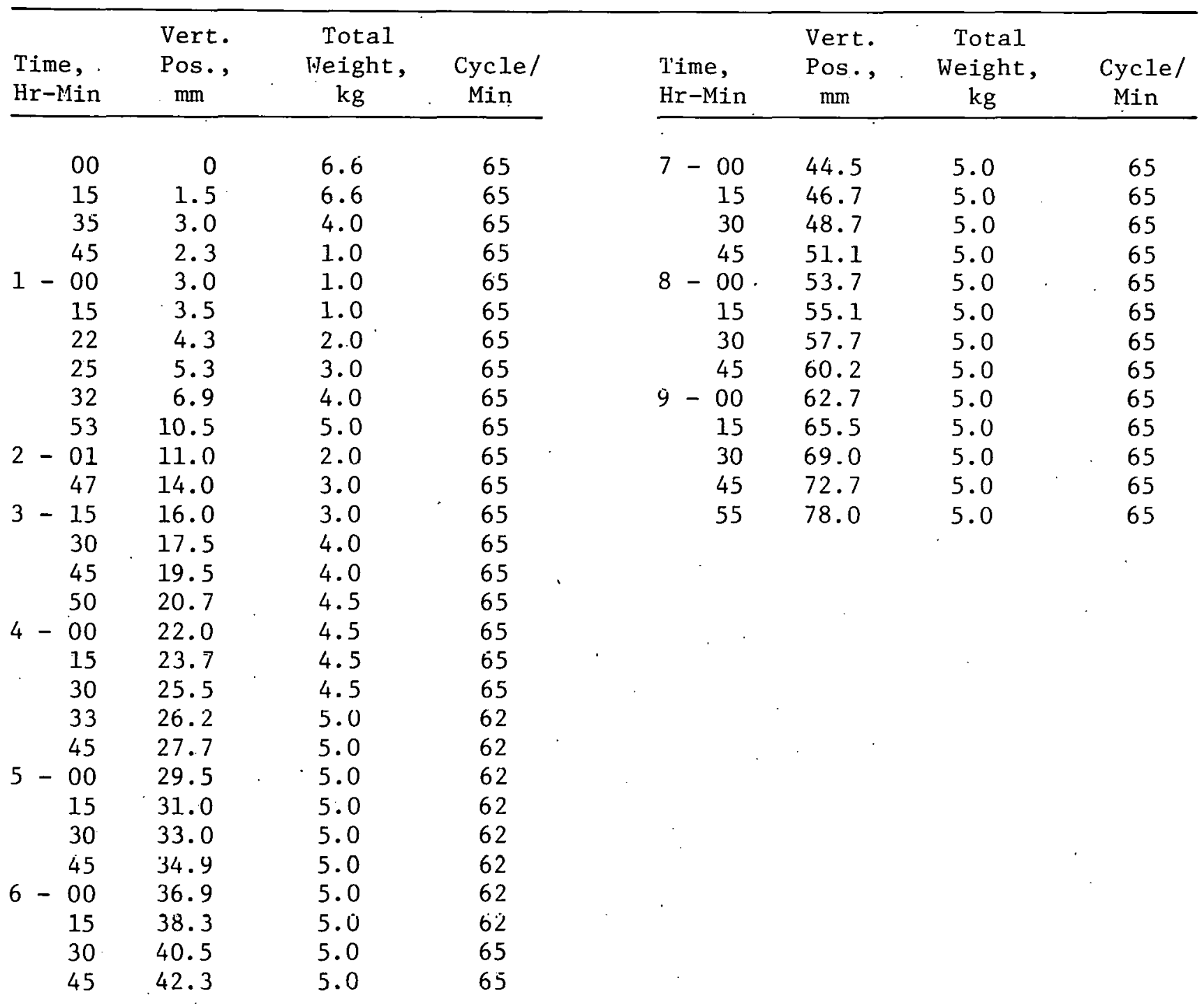


SLICE THICKNESS DATA SHEET

DEMONSTRATION 2

3 Nov. 1977
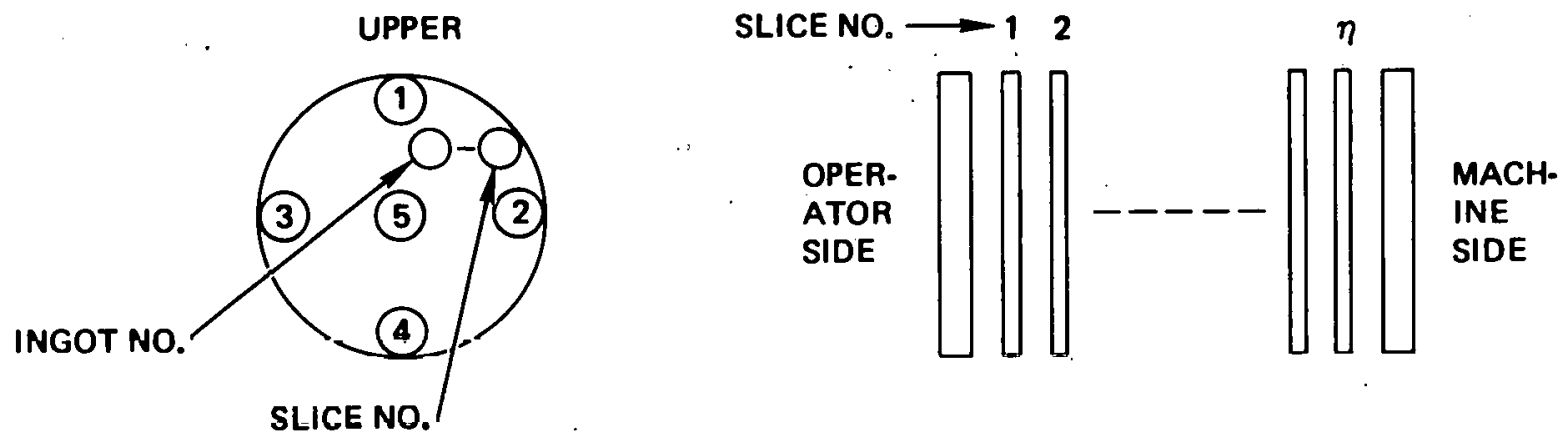

SLICE NO.

\begin{tabular}{|c|c|c|c|c|c|}
\hline Slice No. & (1) & (2) & $\begin{array}{l}3 \\
\mathrm{~mm}\end{array}$ & $\frac{4}{\mathrm{~mm}}$ & (5) \\
\hline 1 & 0.370 & 0.365 & $0: 360$ & 0.370 & 0.360 \\
\hline 5 & 0.360 & 0.360 & 0.359 & 0.364 & 0.363 \\
\hline 10 & 0.365 & 0.360 & 0.359 & 0.373 & 0.363 \\
\hline 15 & 0.372 & 0.369 & 0.368 & 0.374 & 0.374 \\
\hline 20 & 0.362 & 0.363 & 0.364 & 0.366 & 0.368 \\
\hline 25 & 0.380 & 0.379 & 0.376 & 0.377 & 0.379 \\
\hline 30 & 0.365 & 0.360 & 0.360 & 0.365 & 0.365 \\
\hline 35 & 0.380 & 0.370 & 0.370 & 0.381 & 0.378 \\
\hline 40 & 0.313 & 0.348 & 0.347 & 0.350 & 0.351 \\
\hline 45 & 0.369 & 0.358 & 0.362 & 0.370 & 0.367 \\
\hline
\end{tabular}




\section{SAMPLE CUTTING DATA SHEET \\ DEMONSTRATION 3 \\ 4 Nov. 1977}

\section{Specification of Prospect}

1. Materials of workpiece

2. Dimension of work

3. Machine No.

4. Cartridge type

5. Hour put to used of head rollers

Cutting Condition

1. Roller pitch

2. Diameter of wire

3. Abrasive.

4. Lapping oil

5. Ratio of 3 to 4

6. Bond

7. Mean amount of kerf

8. No. of wire under cutting

9. Total weight

10. Mean unit weight

11. Total wire tension

12. Breaking point of wire

13. Feeding amount of wire

14. Reciprocation of wire

15. Wears of wire

16. Total length of used wire

Working Efficiency

1. Total working time

2. Number of works

3. Working time of unit work

4. Total cutting area

5. Total volumes of kerf

6. Mean volumes of kerf

\section{Schematics of Work Installed}

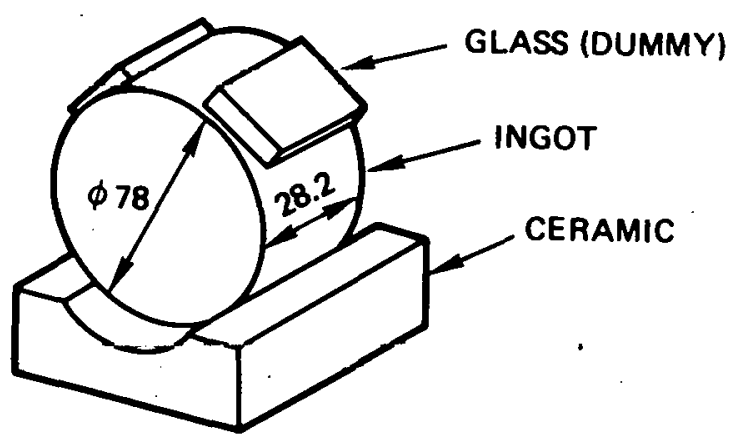

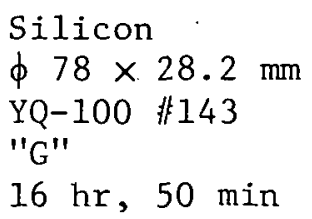

\section{$0.5 \mathrm{~mm}$}

$0.12 \mathrm{~mm}$

Previous use No. 2

and new abrasive $940 \mathrm{~g}$ and new oil $500 \mathrm{~g}$

1.67:1

Sunlock SMD-01

$0.15 \mathrm{~mm}$

45

$\operatorname{Max} 7.2 \mathrm{~kg}$

$\operatorname{Max} 23.1 \mathrm{~g} / \mathrm{cm} /$ wire

$1.2 \mathrm{~kg}$

$3.2 \mathrm{~kg}$

$10.5 \mathrm{~m} / \mathrm{min}$

$65 \sim 68$ cycle/min

$9 \mu \mathrm{m}$

$5050 \mathrm{~m}$

$8 \mathrm{hr}, 25 \mathrm{~min}$

44 pcs

$11.5 \mathrm{~min}$

$2150 \mathrm{~cm}^{2}$

$32.3 \mathrm{~cm}^{3}$

$0.064 \mathrm{~cm}^{3} / \mathrm{min}$ 


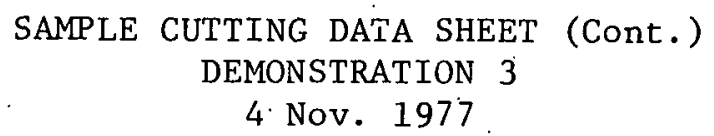

\section{Remarks}

1. For abrasive slurry, $940 \mathrm{~g}$ of GC $\# 1500$ abrasive grain and $500 \mathrm{~g}$ of LAP-OIL was added to used abrasive slurry from No. 2 operation.

2. Used another part of used three-roller set from No. 1 and No. 2 operation.

3. After 85 minutes, operation was stopped for one minuta and a cpaccr inotallcd at the roar of $\mathrm{V}$ roller.

4. Cutting time was too large because of wire delaying during operation, so total weight was decreased. 
TIME-VERTICAL POSITION DATA SHEET

DEMONSTRATION 3

4 Nov. 1977

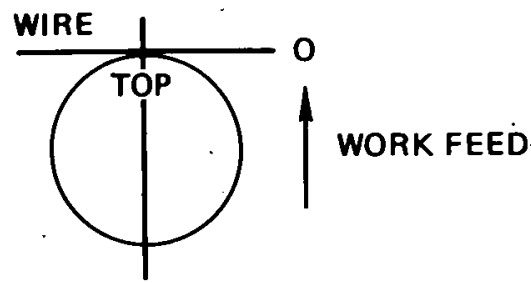

\begin{tabular}{|c|c|c|c|c|c|c|c|}
\hline $\begin{array}{l}\text { Time, } \\
\text { Hr-Min }\end{array}$ & $\begin{array}{c}\text { Vert. } \\
\text { Pos., } \\
\text { mm }\end{array}$ & $\begin{array}{c}\text { Total } \\
\text { Weight, } \\
\text { kg }\end{array}$ & $\begin{array}{l}\text { Cycle/ } \\
\text { Min }\end{array}$ & $\begin{array}{l}\text { Time, } \\
\text { Hr-Min }\end{array}$ & $\begin{array}{l}\text { Vert. } \\
\text { Pos., } \\
\text { mm }\end{array}$ & $\begin{array}{c}\text { Total } \\
\text { Weight, } \\
\text { kg }\end{array}$ & $\begin{array}{c}\text { Cycle/ } \\
\text { Min }\end{array}$ \\
\hline 00 & 0 & 4.0 & 65 & $6-00$ & 37.8 & 5.6 & 68 \\
\hline 15 & 1.7 & 5.6 & 65 & . $\quad 15$ & 41.9 & 5.6 & 68 \\
\hline 30 & 2.7 & 5.6 & 65 & 30 & 45.0 & 5.6 & 68 \\
\hline 45 & 2.5 & 1.0 & 65 & 45 & 48.8 & 5.6 & 68 \\
\hline $1-00$ & 2.5 & 1.0 & 65 & $7-00$ & 52.3 & 5.6 & 68 \\
\hline 15 & 3.5 & 1.0 & 65 & 15 & 56.1 & 5.6 & 68 \\
\hline 30 & 3.5 & 1.0 & 65 & 30 & 60.3 & 5.6 & 68 \\
\hline 40 & 5.0 & 3.0 & 65 & 45 & 65.3 & 5.6 & 68 \\
\hline . $\quad 45$ & 5.1 & 3.0 & 65 & $8-00$ & 69.0 & 5.6 & 68 \\
\hline $2-00$ & 6.1 & 3.0 & 65 & 15 & 74.0 & 5.6 & 68 \\
\hline 15 & 8.7 & 4.0 & 65 & 25 & 78.0 & 5.6 & 68 \\
\hline 30 & 10.9 & 5.0 & 68 & & & & \\
\hline 45 & 12.3 & 5.0 & 68 & & & & \\
\hline $3-00$ & 14.5 & 5.3 & 68 & & & & \\
\hline 15 & 16.5 & 5.6 & 68 & & & & \\
\hline 30 & 18.0 & 5.6 & 68 & & & & \\
\hline 45 & 19.9 & 5.6 & 68 & & & & \\
\hline $4-00$ & 21.7 & 5.6 & 68 & & & & \\
\hline 15 & 23.8 & 5.6 & 68. & & & & \\
\hline 30 & 26.0 & 5.6 & 68 & & & 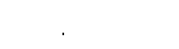 & \\
\hline 45 & 27.9 & 5.6 & 68 & & & & \\
\hline $5-00$ & 29.5 & 5.6 & 68 & & & & \\
\hline 15 & 31.1 & 5.6 & 68 & & & & \\
\hline 30 & 33.7 & 5.6 & 68 & & & & \\
\hline 45 & 36.0 & 5.6 & 68 & & & & \\
\hline
\end{tabular}


SLICE THICKNESS DATA SHEET DEMONSTRATION 3

4 Nov. 1977
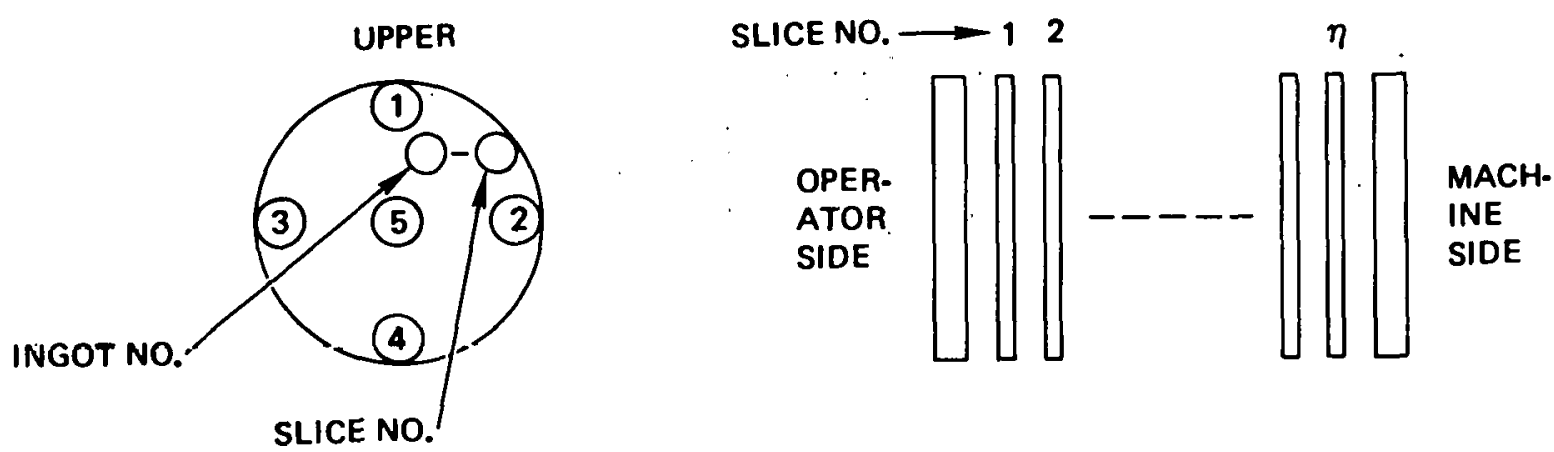

\begin{tabular}{rlllll}
\hline & $(1)$ & $(2)$ & $(3)$ & $(4)$ & $(5)$ \\
S1ice No. & (1) & $\underbrace{}_{\mathrm{mm}}$ & 0.354 & 0.363 & 0.359 \\
1 & 0.355 & 0.362 & 0.364 & 0.366 & 0.365 \\
5 & 0.364 & 0.363 & 0.364 & 0.378 & 0.369 \\
10 & 0.373 & 0.373 & 0.371 & 0.369 & 0.372 \\
15 & 0.365 & 0.373 & 0.365 & 0.372 & 0.362 \\
20 & 0.360 & 0.359 & 0.358 & 0.374 & 0.371. \\
25 & 0.371 & 0.372 & 0.370 & 0.363 & 0.364 \\
30 & 0.361 & 0.367 & 0.360 & 0.353 & 0.349 \\
35 & 0.346 & 0.347 & 0.341 & 0.360 & 0.365 \\
40 & 0.359 & 0.360 & 0.360 & 0.335 & 0.347 \\
44 & 0.349 & 0.347 & 0.349 & & \\
\hline
\end{tabular}




\section{SAMPLE CUTTIING DATA SHEET \\ DEMONSIRATION 4 \\ 8 Nov. 1977}

Specification of Prospect

1. Materials of workpiece

Silicon

2. Dimension of work

3. Machine No.

4. Cartridge type

5. Hour put to used of head rollers

$\phi 78.5 \times 27.3$

Model YQ-100 B-3707

"G"

$0 \mathrm{hr}, 0 \mathrm{~min}$

\section{Cutting Condition}

1. Roller pitch

2. Diameter of wire

3. Abrasive

4. Lapping oil

5. Ratio of 3 to 4

6. Bond

7. Mean amount of kerf

8. No. of wire under cutting

9. Total weight

10. Mean unit weight

11. Total wire tension

12. Breaking point of wire

13. Feeding amount of wire

14. Reciprocation of wire

15. Wears of wire

16. Total length of used wire

$0.4 \mathrm{~mm}$

ф $0.12 \mathrm{~mm}$

New GC \#3000 $(5 \mu \mathrm{m}) 4.5 \mathrm{~kg}$

New $2.8 \mathrm{~kg}$

$1: 1.6$

Sunlock SMD-01

$0.135 \mathrm{~mm}$

55

$\operatorname{Max} 7.6 \mathrm{~kg}$

$\operatorname{Max} 20 \mathrm{~g} / \mathrm{cm} /$ wire

i. $22 \mathrm{~kg}$

$3.2 \mathrm{~kg}$

$12.0 \mathrm{~m} / \mathrm{min}$

$68 \mathrm{cycle} / \mathrm{min}$

$5 \mu \mathrm{m}$

$9000 \mathrm{~m}$

Working Efficiency

1. Total working time

2. Number of works

3. Working time of unit work

4. Total cutting area

5. Total volumes of kerf

6. Mean volumes of kerf
$12 \mathrm{hr}, 30 \mathrm{~min}$

54 pcs

$13.9 \mathrm{~min}$

$2660.6 \mathrm{~cm}^{2}$

$35.9 \mathrm{~cm}^{3}$

$0.0479 \mathrm{~cm}^{3} / \mathrm{min}$

Schematics of Work Installed

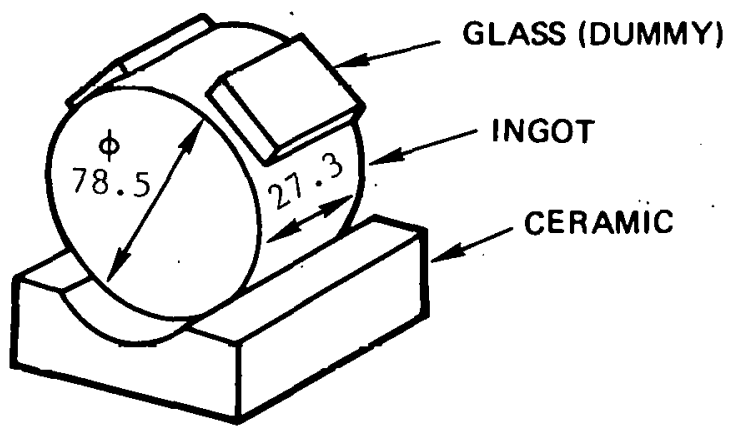




\section{SAMPLE CUTTING DATA SHEET (Cont.) \\ DEMONSTRATION 4 \\ 8 Nov. 1977}

$\underline{\text { Remarks }}$

1. Used new three-roller set, abrasive slurry and drive roller about $55 \mathrm{~mm}$ diameter.

2. As circular surface of ingot is not smooth as in following figure, two dummy glasses were bonded on ingot.

3. Spended cutting time was too large and, consequently, wire was delayed a little because both dummy glasses are not symmetrical.

4. Finished cutting surface is not good. At a cutting rondition with GC \#3000 and wire $0.12 \mathrm{~mm}$ diameter, it is necessary to pay much time.

Cutting under these conditions is difficult. We must study the cutting operation further.

5. About calculation for cutting weight, we decided that work's width is as follows:

$$
\frac{D \times \sqrt{\pi}}{2}-\frac{78.5 \times \sqrt{3.14}}{2}=69.55 \text { ини }
$$

where

$\mathrm{D}$ is work diameter

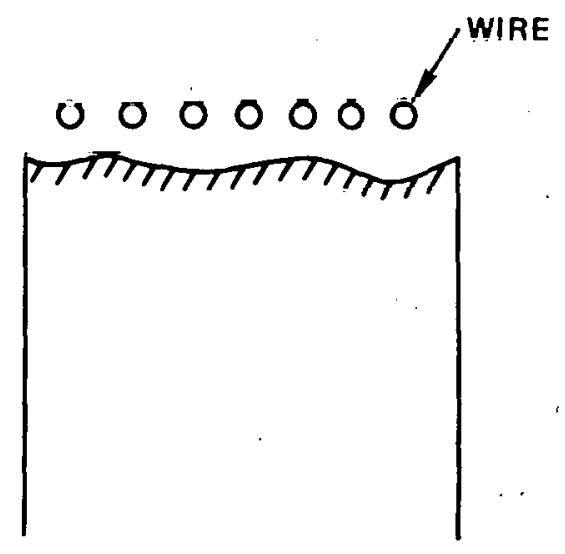




\section{TIME-VERTICAL POSITION DATA SHEET}

DEMONSTRATION 4

8 Nov. 1977

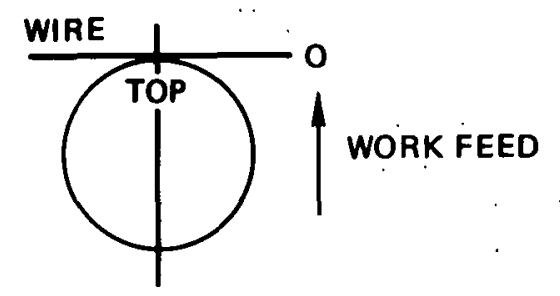

\begin{tabular}{|c|c|c|c|c|c|c|c|}
\hline $\begin{array}{l}\text { Time, } \\
\text { Hr-Min }\end{array}$ & $\begin{array}{c}\text { Vert. } \\
\text { Pos., } \\
\text { mm }\end{array}$ & $\begin{array}{c}\text { Total } \\
\text { Weight, } \\
\text { kg }\end{array}$ & $\begin{array}{c}\text { Cycle/ } \\
\text { Min }\end{array}$ & $\begin{array}{l}\text { Time, } \\
\text { Hr-Min }\end{array}$ & $\begin{array}{c}\text { Vert. } \\
\text { Pos., } \\
\text { mm }\end{array}$ & $\begin{array}{c}\text { Total } \\
\text { Weight, } \\
\mathrm{kg}\end{array}$ & $\begin{array}{c}\text { Cycle/ } \\
\text { Min }\end{array}$ \\
\hline $0-00$ & 0 & 3.0 & 65 & $7-00$ & 35.8 & 7.6 & 68 \\
\hline 15 & 0.5 & 3.0 & 65 & 15 & 37.8 & 7.6 & 68 \\
\hline 30 & 1.2 & 3.0 & 65 & 30 & 39.7 & 7.6 & 68 \\
\hline 45 & 2.0 & 3.0 & 65 & 45 & 41.7 & 7.6. & 68 \\
\hline $1-00$ & 2.5 & 3.0 & 65 & $8-00$ & 43.8 & 7.6 & 68 \\
\hline 15 & 2.8 & 4.0 & 65 & 15 & 45.6 . & 7.6 & 68 \\
\hline 30 & 3.0 & $4: 0$ & 65 & 30 & $47.55^{\circ}$ & 7.6 & 68 \\
\hline 45 & 3.8 & 4.0 & 65 & 45 & 49.4 & 5.0 & 68 \\
\hline $2-00$ & 4.3 & 4.0 & 65 & $9-00$ & 49.9 & 5.0 & 68 \\
\hline . 15 & 5.4 & 4.0 & 65 & 15 & 51.2 & 5.0 & 68 \\
\hline 30 & 6.5 & 2.0 & 65 & 30 & 52.5 & 6.0 & 68 \\
\hline 45 & 6.0 & 2.0 & 65 & 45 & 54.5 & 6.0 & 68 \\
\hline $3-00$ & 6.5 & 2.0 & 65 & $10-00$ & 56.2 & 6.0 & 68 \\
\hline 15 & 6.8 & 4.0 & 68 & 15 & 57.85 & 6.0 & 68 \\
\hline 30 & 9.2 & 4.0 & 68 & 30 & 59.7 & 6.0 & 68 \\
\hline 45 & 10.5 & 4.0 & 68 & 45 & 61.5 & 6.0 & 68 \\
\hline $4-00$ & 12.8 & 5.0 & 68 & 11. -00 & 63.5 & 6.0 & 68 \\
\hline 15 & 15.0 & 5.5 & 68 & 15 & 65.37 & 6.0 & 68 \\
\hline 30 & 16.0 & 6.0 & 68 & 30 & 67.7 & 6.0 & 68 \\
\hline 45 & 19.0 & 6.0 & 68 & 45 & 70.0 & 4.0 & 68 \\
\hline $5-00$ & 20.5 & 6.0 & 68 & $12-00$ & 70.75 & 4.0 & 68 \\
\hline 15 & 22.0 & 7.6 & 68 & 15 & 73.8 & 5.0 & 68 \\
\hline 30 & 24.7 & 7.6 & 68 & 30 & 78.5 & 5.0 & 68 \\
\hline 45 & 27.0 & 7.6 & 68 & 45 & & & \\
\hline $6-00$ & 28.5 & 7.6 & 68 & & & & \\
\hline 15 & 30.3 & 7.6 & 68 & & & & \\
\hline 30 & 32.2 & 7.6 & 68 & & & & \\
\hline 45 & 34.05 & 7.6 & 68 & & & & \\
\hline
\end{tabular}


SLICE THICKNESS DATA SHEET

DEMONSTRATION 4

.8 Nov. 1977

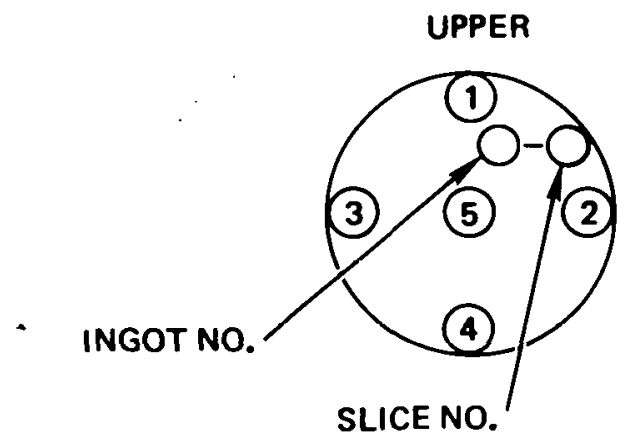

SLICE NO.

$\longrightarrow-12$

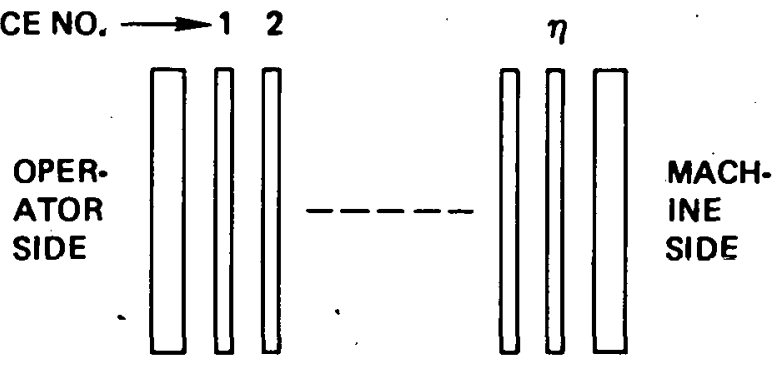

$\eta$

SLICE NO.

\begin{tabular}{|c|c|c|c|c|c|}
\hline Slice No. & $(1)$ & $\underbrace{2}_{\mathrm{mm}}$ & $=\frac{3}{\mathrm{~mm}}$ & $(4)$ & 5 \\
\hline 1 & 0.271 & 0.278 & 0.281 & 0.296 & 0.277 \\
\hline 5 & 0.267 & 0.286 & 0.292 & 0.296 & 0.295 \\
\hline 10 & 0.274 & 0.295 & 0.290 & 0.305 & 0.297 \\
\hline 15 & 0.268 & .0 .264 & 0.268 & 0.275 & 0.264 \\
\hline 20 & 0.272 & 0.276 & 0.276 & 0.270 & 0.280 \\
\hline 25 & 0.273 & 0.255 & 0.255 & 0.268 & 0.250 \\
\hline 30 & 0.266 & 0.260 & 0.258 & 0.270 & 0.258 \\
\hline 35 & 0.280 & 0.290 & 0.291 & 0.280 & $0.3 \cap 3$ \\
\hline 40 & 0.263 & 0.280 & 0.291 & 0.280 & 0.288 \\
\hline 45 & 0.270 & 0.258 & 0.255 & 0.261 & 0.253 \\
\hline 50 & 0.266 & 0.290 & 0.291 & 0.286 & 0.300 \\
\hline 54 & 0.290 & 0.313 & 0.310 & 0.298 & 0.330 \\
\hline
\end{tabular}




\section{SAMPLE CUTTING DATA SHEET \\ DEMONSTRATION 5 \\ 9 Nov. 1977.}

Specification of Prospect

1. Materials of workpiece

2. Dimension of work

3. Machine No.

4. Cartridge type

5. Hour put to used of head rollers

\section{Cutting Condition}

1. Roller pitch

2. Diameter of wire

3. Abrasive

4. Lapping oil

5. Ratio of 3 to 4

6. Bond

7. Mean amount of kerf

8. No. of wire under cutting

9. Total weight

10. Mean unit weight

11. Total wire tension

12. Breaking point of wire

13. Feeding amount of wire

14. Reciprocation of wire

15. Wears of wire

16. Total length of used wire

\section{Working Efficiency}

1. Total working time

2. Number of works

3. Working time of unit work:

4. Total cutting area

5. Total volumes of kerf

6. Mean volumes of kerf

Schematics of Work Installed

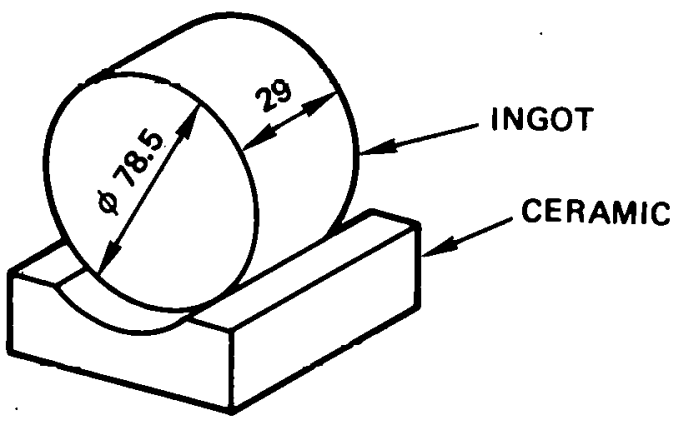

Silicon

p. $78.5 \times 29$

YQ-100 B-3707

"G"

$0 \mathrm{hr}, 00 \mathrm{~min}$

$0.4 \mathrm{~mm}$

$\phi 0.12 \mathrm{~mm}$

Previous use No. 4

Sunlock SMD-01

$0.135 \mathrm{~mm}$

55

$\operatorname{Max} 7.6 \mathrm{~kg}$

$\operatorname{Max} 20 \mathrm{~g} / \mathrm{cm} /$ wire

$1.25 \mathrm{~kg}$

$3.2 \mathrm{~kg}$

$11.5 \mathrm{~m} / \mathrm{min}$

$68 \mathrm{cycle} / \mathrm{min}$

$5 \mu \mathrm{m}$

$6727 \mathrm{~m}$

$9 \mathrm{hr}, 45 \mathrm{~min}$

54 pcs

$10.8 \mathrm{~min}$

$2660.6 \mathrm{~cm}^{2}$

$35.9 \mathrm{~cm}^{3}$

$0.0614 \mathrm{~cm}^{3} / \mathrm{min}$ 


\section{SAMPLE CUTTING DATA SHEET (Cont.) \\ DEMONSTRATION 5 \\ 9 Nov. 1977}

\section{Remarks:}

1. Used the same three-roller set and abrasive slurry as No. 4 ingot operation.

2. As in No. 4 operation, used MDC depth control with stopper serving to protect wire slipping. 


\section{TIME-VERTICAL POSITION DATA SHEET \\ DEMONSTRATION 5 \\ 9 Nov. 1977}

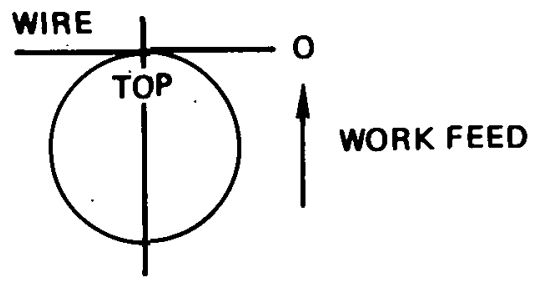

\begin{tabular}{|c|c|c|c|c|c|c|c|}
\hline $\begin{array}{l}\text { Time, } \\
\text { Hr-Min }\end{array}$ & $\begin{array}{c}\text { Vert. } \\
\text { Pos., } \\
\text { mm }\end{array}$ & $\begin{array}{c}\text { Total } \\
\text { Weight, } \\
\text { kg }\end{array}$ & $\begin{array}{c}\text { Cycle/ } \\
\text { Min }\end{array}$ & $\begin{array}{l}\text { Time, } \\
\text { Hr-liin }\end{array}$ & $\begin{array}{c}\text { Vert. } \\
\text { Pos., } \\
\text { mm }\end{array}$ & $\begin{array}{c}\text { Total } \\
\text { Weight, } \\
\text { kg }\end{array}$ & $\begin{array}{c}\text { Cycle/ } \\
\text { lin }\end{array}$ \\
\hline $0-00$ & 0 & 2.0 & 68 & $5-00$ & 40.02 & 7.6 & 68 \\
\hline 15 & 1.22 & 2.0 & 68 & 15 & 42.35 & 7.6 & 68 \\
\hline 30 & 2.94 & 2.0 & 68 & 30 & 44.5 & 7.6 & 68 \\
\hline 45 & 5.45 & 3.0 & 68 & 45 & 47.0 & 7.6 & 68 \\
\hline $1-00$ & 7.15 & 3.0 & 68 & $6-00$ & 49.15 & 7.6 & 68 \\
\hline 15 & 8.7 & 4.0 & 68 & 15 & 51.4 & 7.6 & 68 \\
\hline 30 & 10.9 & 4.0 & 68 & 30 & 53.65 & 7.6 & 68 \\
\hline 45 & 12.5 & 4.0 & 68 & 45 & 56.15 & 7.6 & 68 \\
\hline $2-00$ & 14.15 & 5.0 & 68 & $7-00$ & 58.6 & 4.0 & 68 \\
\hline 15 & 16.5 & 5.0 & 68 & 15 & 58.85 & 4.0 & 68 \\
\hline 30 & 18.25 & 5.0 & 68 & 30 & 60.32 & 4.0 & 68 \\
\hline 45 & 19.8 & 7.6 & 68 & 45 & 61.7 & 4.0 & 68 \\
\hline $3-00$ & 23.2 & 7.6 & 68 & $8-00$ & 63.35 & 4.0 & 68 \\
\hline 15 & 25.4 & 7.6 & 68 & 15 & 65.0 & 4.0 & 68 \\
\hline 30 & 27.6 & 7.6 & 68 & 30 & 66.95 & 4.0 & 68 \\
\hline 45 & 29.75 & 7.6 & 68 & 45 & 68.65 & 4.0 & 68 \\
\hline $4-00$ & 31.85 & 7.6 & 68 & $9-00$ & 70.6 & 4.0 & 68 \\
\hline 15 & 33.9 & 7.6 & 68 & 15 & 72.75 & 4.0 & 68 \\
\hline 30 & 35.95 & 7.6 & 68. & 30 & 75.3 & 4.0 & 68 \\
\hline 45 & 38.15 & 7.6 & 68 & 45 & 78.5 & 4.0 & 68 \\
\hline
\end{tabular}




\section{SLICE THICKNESS DATA SHEET \\ DEMONSTRATION 5 \\ 9 Nov. 1977}
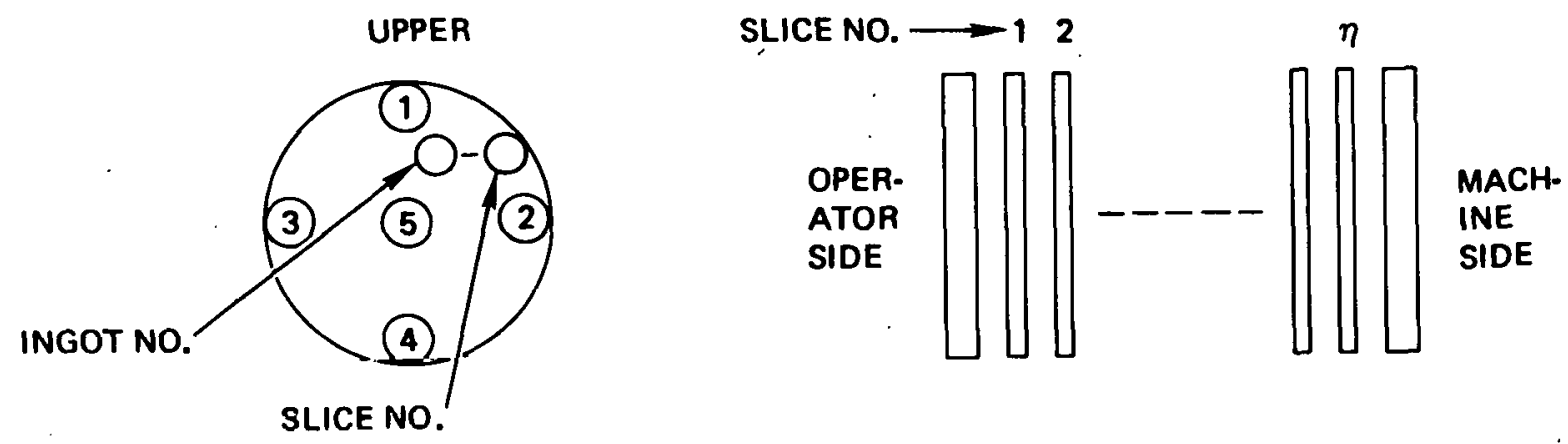

SLICE NO.'

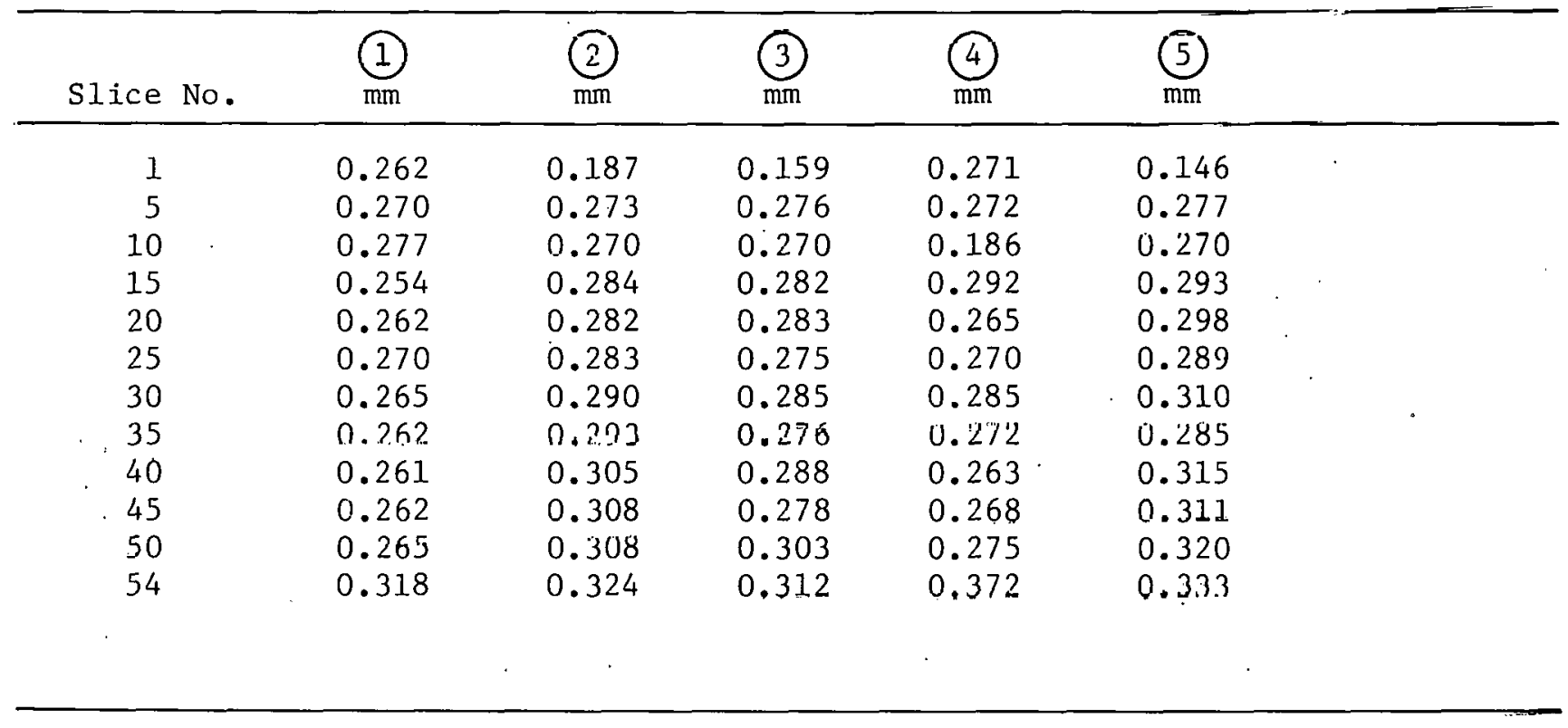




\section{Specification of Prospect}

1. Materials of workpiece

2. Dimension of work

3. Machine No.

4. Cartridge type

5. Hour put to used of head rollers

\section{Cutting Condition}

1. Roller pitch

2. Diameter of wire

3. Abrasive

4. Lapping oil

5. Ratio of 3 to 4

6. Bond

7. Mean amount of kerf

8. No. of wire under cutting

9. Total weight

10. Mean unit weight

11. Total wire tension

12: Breaking point of wire

13. Feeding amount of wire

14. Reciprocation of wire

15. Wears of wire

16. Total length of used wire

Working Efficiency

1. Total working time

2. Number of works

3. Working time of unit work

4. Total cutting area

5. Total volumes of kerf

6 . Mean volumes of kerf

\section{Schematics of Work Installed}

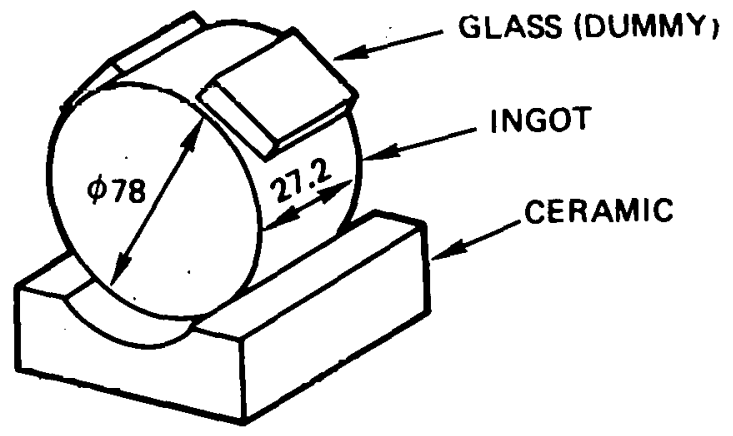

\section{Silicon}

中 $78 \times 27.2$

YQ-100 \#143

"G"

$0 \mathrm{hr}, 0 \mathrm{~min}$

$0.4 \mathrm{~mm}$

$0.12 \mathrm{~mm}$

New GC 非1500 $(10 \mu \mathrm{m}) 5.2 \mathrm{~kg}$

New $0 i 13.4 \mathrm{~kg}$

1.53:1

Sunlock SMD-01

$0.15 \mathrm{~mm}$

55

$\operatorname{Max} 7 \mathrm{~kg}$

$\operatorname{Max} 18.4 \mathrm{~g} / \mathrm{cm} /$ wire

$1.2 \mathrm{~kg}$

$3.2 \mathrm{~kg}$

$10 \mathrm{~m} / \mathrm{min}$

$65 \mathrm{cycle} / \mathrm{min}$

$6 \mu \mathrm{m}$

$4800 \mathrm{~m}$

$8 \mathrm{hr}, 0 \mathrm{~min}$

54 pes

$8.9 \mathrm{~min}$

$2628 \mathrm{~cm}^{2}$

$39.4 \mathrm{~cm}^{3}$

$0.082 \mathrm{~cm}^{3} / \mathrm{min}$ 


\section{SAMPLE CUTTING DATA SHEET (Cont.) \\ DEMONSTRATION 6 \\ 5 Nov. 1977}

\section{Remarks}

1. After 22 minutes of cutting in silicon ingot, one wire at middle of head roller was flying up, so it was mended and operation continued.

2. The time required for this mending time was subtracted from actual cutting time. 


\section{TIME-VERTICAL POSITION DATA SHEET \\ DEMONSTRATION 6 \\ 5 Nov. 1977}

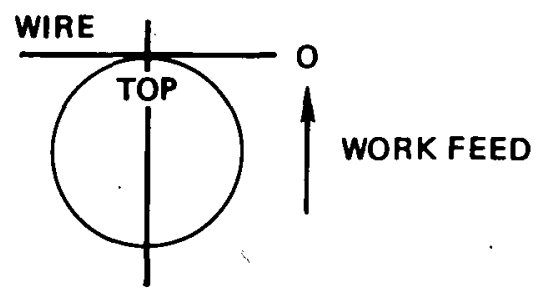

\begin{tabular}{|c|c|c|c|c|c|c|c|}
\hline $\begin{array}{l}\text { Time, } \\
\text { Hr-Min }\end{array}$ & $\begin{array}{c}\text { Vert. } \\
\text { Pos., } \\
\text { mm }\end{array}$ & $\begin{array}{c}\text { Total } \\
\text { Weight, } \\
\text { kg }\end{array}$ & $\begin{array}{l}\text { Cycled } \\
\text { Min }\end{array}$ & $\begin{array}{l}\text { Time, } \\
\text { Hr-Min }\end{array}$ & $\begin{array}{c}\text { Vert. } \\
\text { Pos., } \\
\text { mm }\end{array}$ & $\begin{array}{c}\text { Tota1 } \\
\text { Weight, } \\
\text { kg }\end{array}$ & $\begin{array}{c}\text { Cycle/ } \\
\text { Min }\end{array}$ \\
\hline 00 & 0 & 3.0 & 65 & $5-00$ & 38.8 & 7.0 & 65 \\
\hline 15 & 0.3 & 3.0 & 65 & 15 & 41.4 & 7.0 & 65 \\
\hline 30 & 1.6 & 3.0 & 65 & 30 & 44.0 & 7.0 & 65 \\
\hline 45 & 2.3 & 3.0 & 65 & 45 & 46.6 & 7.0 & 65 \\
\hline $1-00$ & 2.8 & 3.0 & 65 & $6-00$ & 49.3 & 7.0 & 65 \\
\hline 15 & 4.1 & 3.5 & 65 & 15 & 52.3 & 7.0 & 65 \\
\hline 30 & 5.3 & 4.0 & 65 & 30 & 54.8 & 7.0 & 65 \\
\hline .45 & 7.0 & 4.5 & 65 & 45 & 57.6 & 7.0 & 65 \\
\hline $2-00$ & 9.0 & 5.0 & 65 & $7-00$ & 60.6 & 7.0 & 65 \\
\hline 15 & 11.8 & 5.5 & 65 & 15 & 63.8 & 7.0 & 65 \\
\hline 30 & 15.0 & 6.0 & 65 & 30 & 68.3 & 7.0 & 65 \\
\hline 45 & 17.3 & 6.0 & 65 & 45 & 72.3 & 7.0 & 65 \\
\hline $3-00$ & 20.1 & 6.0 & 65 & $8-00$ & 78.0 & 7.0 & 65 \\
\hline 15 & 22.5 & 6.0 & 65 & & & & \\
\hline 30 & 24.8 & 6.0 & 65 & & & & \\
\hline 45 & 27.3 & 6.0 & 65 & & & & \\
\hline $4-00$ & 29.3 & 6.0 & 65 & & & & \\
\hline 15 & 32.3 & 6.0 & 65 & & & & \\
\hline 30 & 34.8 & 6.0 & 65 & & & & \\
\hline 45 & 36.8 & 6.5 & 65 & . & & & \\
\hline
\end{tabular}




\section{SLICE THICKNESS DATA SHĖET \\ DEMONSTRATION. 6 \\ 5 Nov. 1977}
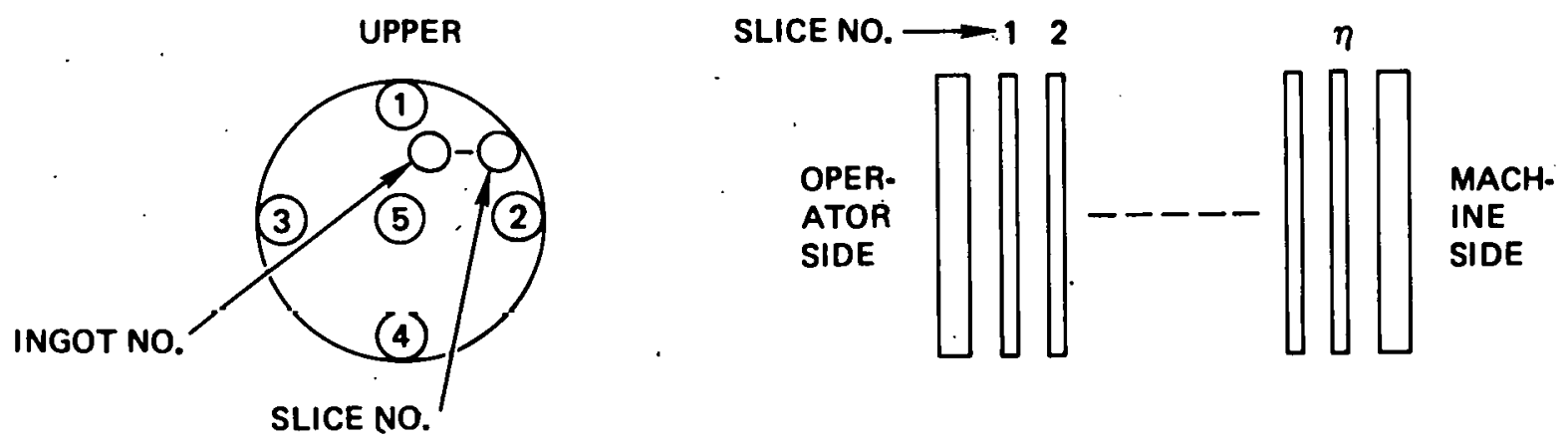

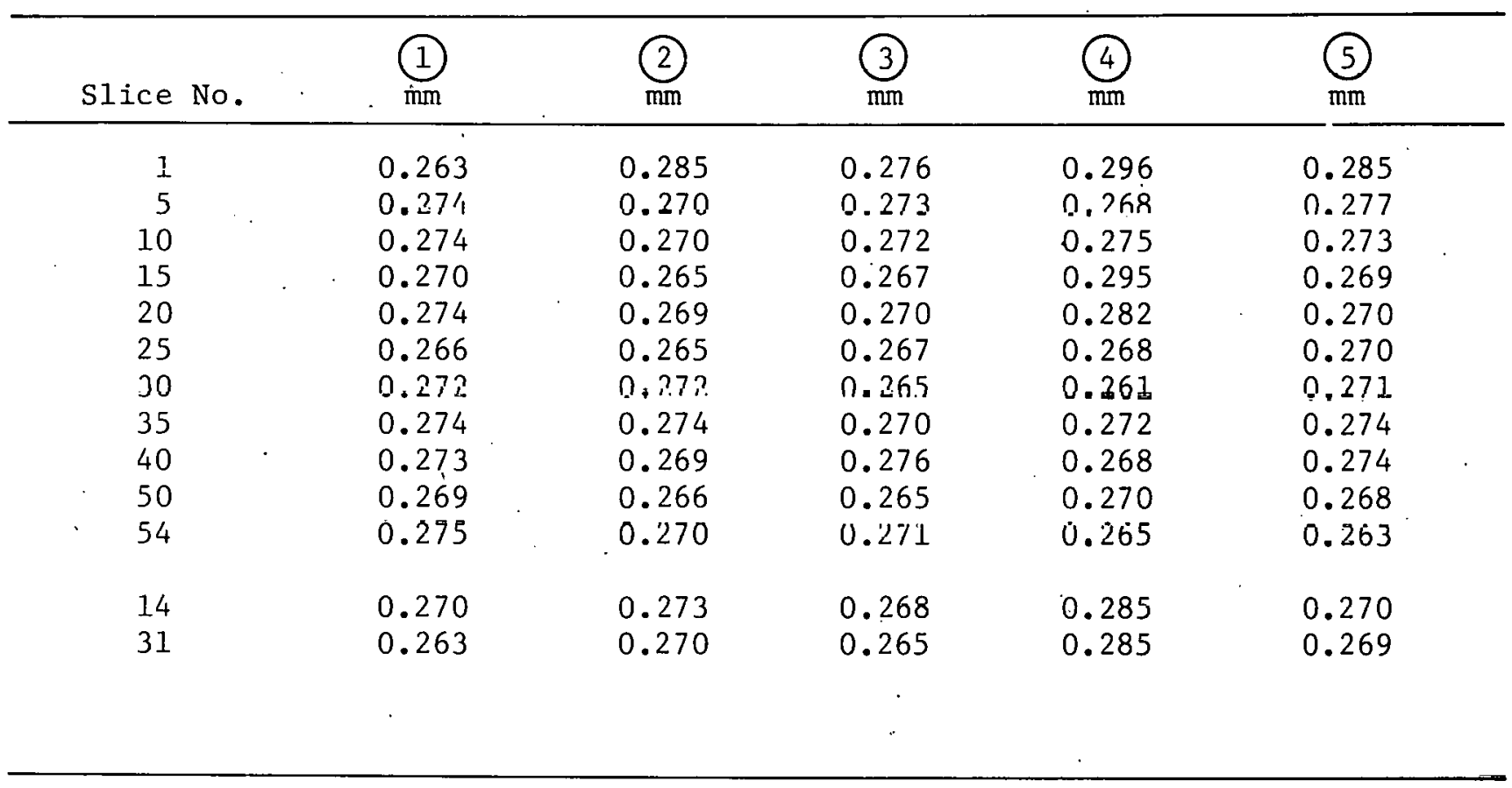


Specification of Prospect

1. Materials of workpiece

Silicon

2. Dimension of work

$\phi 78 \times 27.2$

3. Machine No.

4. Cartridge type

YQ-100 非143

"G"

5. Hour put to used of head rollers

$8 \mathrm{hr}, 17 \mathrm{~min}$

\section{Cutting Condition}

1. Roller pitch

2. Diameter of wire

3. Abrasive

4. Lapping oil

5. Ratio of 3 to 4 ,

6. Bond

7. Mean amount of kerf

8. No. of wire under cutting

9. Total weight

10. Mean unit weight

11. Total wire tension

12. Breaking point of wire

13. Feeding amount of wire

14. Reciprocation of wire

15. Wears of wire

16. Total length of used wire

\section{Working Efficiency}

1. Total working time

2. Number of works

3. Working time of unit work

4. Total cutting area

5. Total volumes of kerf

6. Mean volumes of kerf

Schematics of Work Installed

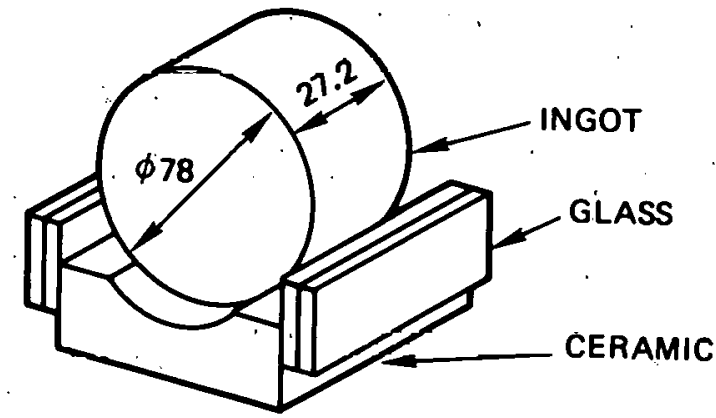

$0.4 \mathrm{~mm}$

$0.12 \mathrm{~mm}$

Previous use No. 6

Sunlock SMD-01

$0.15 \mathrm{~mm}$

55

$\operatorname{Max} 8.6 \mathrm{~kg}$

$\operatorname{Max} 23.1 \mathrm{~g} / \mathrm{cm} /$ wire

$1.2 \mathrm{~kg}$

$3.2 \mathrm{~kg}$

$10 \mathrm{~m} / \mathrm{min}$

67 cycle/min

$9 \mu \mathrm{m}$

$4050 \mathrm{~m}$

$6 \mathrm{hr}, 45 \mathrm{~min}$

54 pcs

$7.5 \mathrm{~min}$

$2628 \mathrm{~cm}^{2}$

$39.4 \mathrm{~cm}^{3}$

$0.097 \mathrm{~cm}^{3} / \mathrm{min}$ 


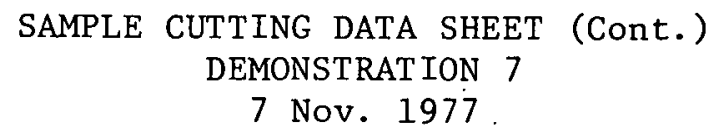

7 Nov. 1977

\section{Remarks}

1. Used same three-roller set which was used already for No. 6 operation, but wound wire on another part of roller.

2. However, to measure sliced wafers in operations No. 1, No. 2, No. 3 and No. 6, the lower part thickness of each wafer was too large in deviation, and so a dummy glass was installed as shown below.

3. For No. 1, No. 2, No. 3, and No. 6 ingot after cutting was finished, the wire was removed from ingot by cutting it off.

At this time, we tried a way in which work was dropped down slowly, but we again were unsuccessful and cut wire again.

Consequently, there was a brushing mark at the lower part of the wafer.

4. The cross section of No. 16 and No. 17 of wafer were as shown below. These may have been caused by wire slipping down.

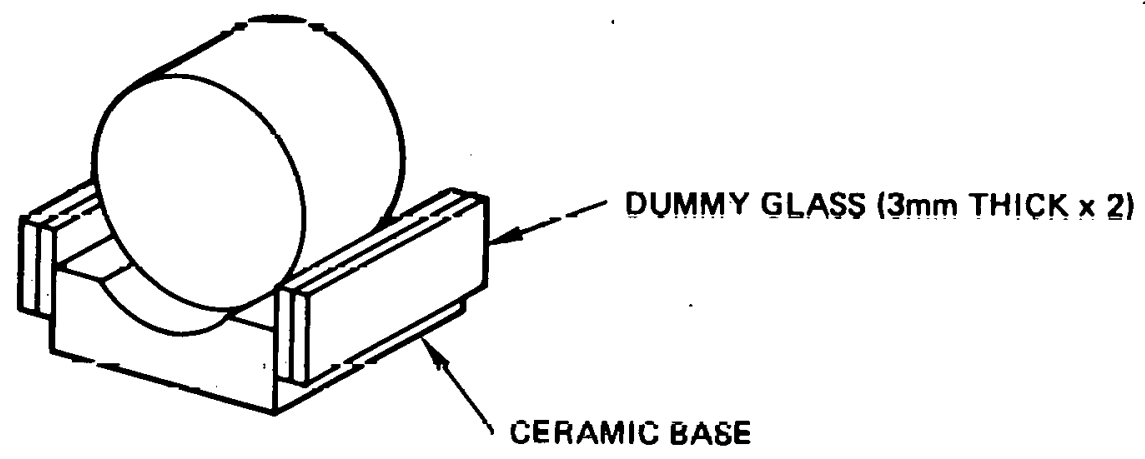

NO. 18

NO. 17
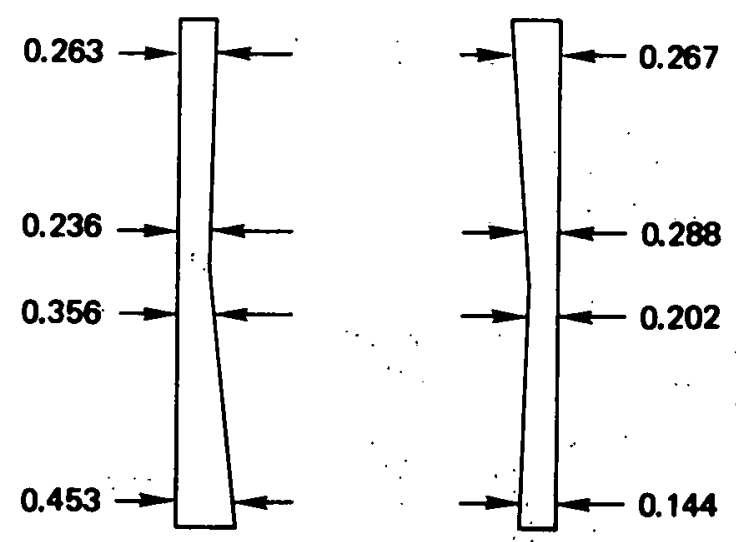
TIME-VERTICAL POSITION DATA SHEET

DEMONSTRATION 7.

7 Nov. 1977

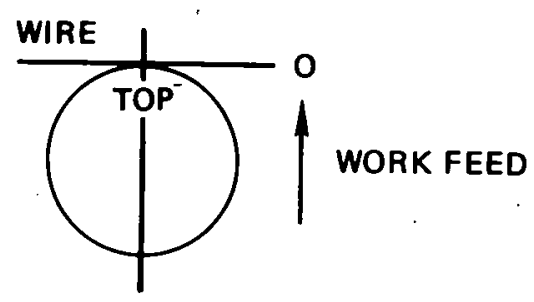

\begin{tabular}{|c|c|c|c|c|c|c|c|}
\hline $\begin{array}{l}\text { Time, } \\
\text { Hr-Min }\end{array}$ & $\begin{array}{l}\text { Vert. } \\
\text { Pos., } \\
\text { mm }\end{array}$ & $\begin{array}{l}\text { Total } \\
\text { Weight, } \\
\text { kg }\end{array}$ & $\begin{array}{l}\text { Cycle/ } \\
\text { Min }\end{array}$ & $\begin{array}{l}\text { Time, } \\
\text { Hr-Min }\end{array}$ & $\begin{array}{l}\text { Vert. } \\
\text { Pos., } \\
\text { mm }\end{array}$ & $\begin{array}{l}\text { Total } \\
\text { Weight, } \\
\text { kg }\end{array}$ & $\begin{array}{c}\text { Cycle/ } \\
\text { Min }\end{array}$ \\
\hline 00 & 0 & 1.5 & 67 & $5-00$ & 65.0 & 7 & 67 \\
\hline 05 & 1.5 & 2.0 & 67 & 15 & 67.0 & 7 & 67 \\
\hline 10 & 2.7 & 2.5 & 67 & 30 & 69.0 & 7 & 67 \\
\hline 15 & 4.0 & 3.0 & 67 & 45 & 70.5 & 7 & 67 \\
\hline 20 & 5.0 & 3.5 & 67 & $6-00$ & 73.0 & 6 & 67 \\
\hline 25 & 5.5 & 4.0 & 67 & 15 & 74.3 & 6 & 67 \\
\hline 30 & 7.5 & 4.5 & 67 & 30 & 76.0 & 6 & 67 \\
\hline 35 & 8.5 & 5.0 & 67 & 45 & 78. & 6 & 67 \\
\hline 45 & 11.0 & 6.0 & 67 & & & & \\
\hline $1-00$ & 14.5 & 6.5 & 67 & & & & \\
\hline 15 & 18.2 & 7.5 & 67 & & & & \\
\hline 30 & 21.5 & 8.0 & 67 & & & & \\
\hline 45 & 25.5 & 8.6 & 67 & & & & \\
\hline $2-00$ & 28.3 & 8.6 & 67 & & & & \\
\hline 15 & 31.5 & 8.6 & 67 & - & & & \\
\hline 30 & 34.3 & 8.6 & 67. & & & & \\
\hline 45 & 37.5 & 8.6 & 67 & · & & & \\
\hline $3-00$ & 41.0 & 8.6 & 67 & & & & \\
\hline 15 & 44.0 & 8.6 & 67 & & & & \\
\hline 30 & 46.8 & 8.6 & $67^{\circ}$ & & & & \\
\hline 45 & 49.8 & 8.6 & 67 & & & & \\
\hline $4-00$ & 53.0 & 8.0 & 67 & & & & \\
\hline 15 & 56.0 & 8.0 & 67 & & & & \\
\hline 30 & 59.5 & 8.0 & 67 & & & & \\
\hline 45 & 62.7 & 8.0 & 67 & & & & \\
\hline
\end{tabular}




\section{SLICE THICKNESS : DATA SHEET}

DEMONSTRATION 7

7 Nov. 1977
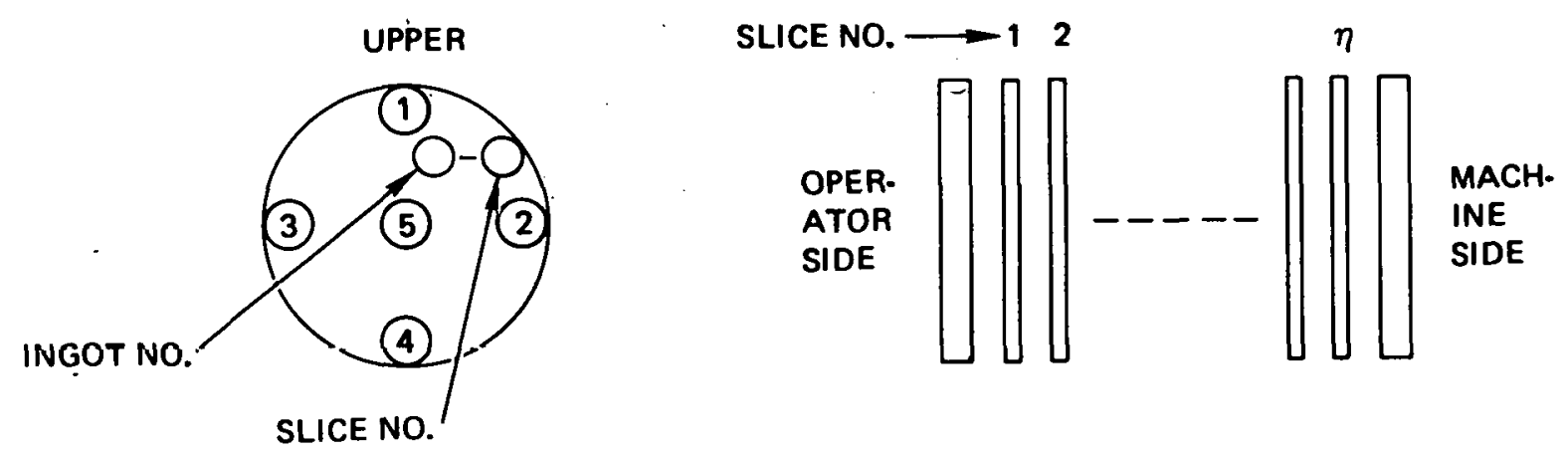

\begin{tabular}{|c|c|c|c|c|c|}
\hline Slice No. & $(1)$ & $(2)$ & (3) & $\underset{\mathrm{mm}}{4}$ & (5) \\
\hline 1 & 0.252 & 0.180 & 0.192 & 0.192 & 0.160 \\
\hline 5 & 0.270 & 0.259 & 0.259 & 0.270 & 0.259 \\
\hline 10 & 0.271 & 0.270 & 0.272 & 0.284 & 0.274 \\
\hline 15 & 0.272 & 0.274 & 0.275 & 0.270 & 0.282 \\
\hline 20 & 0.262 & 0.267 & 0.285 & 0.257 & 0.271 \\
\hline 25 & 0.266 & 0.262 & 0.263 & 0.272 & 0.265 \\
\hline 30 & $0.26 \Omega$ & ก. 26? & 0.268 & 0.269 & 0.370 \\
\hline 35 & 0.271 & 0.266 & 0.265 & 0.268 & 0.268 \\
\hline 40 & 0.271 & 0.269 & 0.268 & 0.273 & 0.276 \\
\hline 45 & 0.267 & 0.266 & 0.269 & 0.260 & 0.269 \\
\hline 50 & 0.268 & 0.268 & 0.266 & 0.271 & 0.272 \\
\hline 55 & 0.265 & 0.270 & 0.267 & 0.267 & 0.268 \\
\hline & & & & & \\
\hline
\end{tabular}




\section{SAMPLE CUTTING DATA SHEET \\ DEMONSTRATION 8 \\ 8 Nov. 1977}

Specification of Prospect

1. Materials of workpiece

Silicon

2. Dimension of work

$\phi 78 \times 27: 3$

3. Machine No.

4. Cartridge type

5. Hour put to used of head rollers

YQ-100 非 143

"G"

\section{Cutting Condition}

1. Roller pitch

2. Diameter of wire

3. Abrasive

4. Lapping oil

5. Ratio of 3 to 4

6. Bond

7. Mean amount of kerf

8. No. of wire under cutting

9. Total weight

10. Mean unit weight

11. Total wire tension

12. Breaking point of wire

13. Feeding amount of wire

14. Reciprocation of wire

15. Wears of wire

16. Total length of used wire

$15 \mathrm{hr}, 12 \mathrm{~min}$

Working Efficiency

1. Total working time

2. Number of works

3. Working time of unit work

4. Tota1 cutting area

5. Total volumes of kerf

6. Mean volumes of kerf

Schematics. of Work Installed

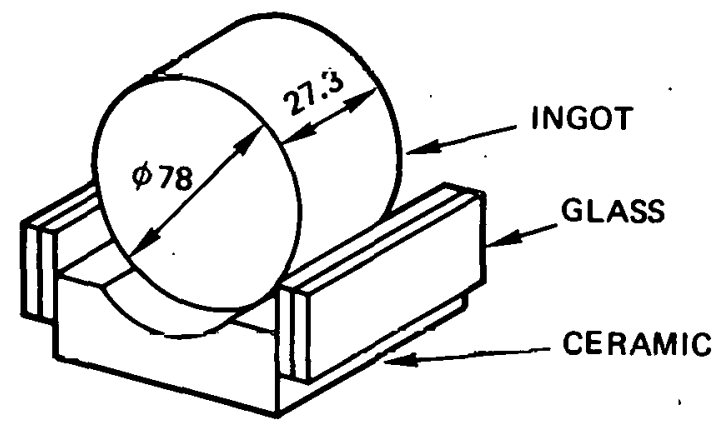

$0.4 \mathrm{~mm}$

$0.12 \mathrm{~mm}$

Previous use No. 6, No. 7 and No. 3 ( $1 \mathrm{~kg}$ )

Sunlock SMD-0I

$0.15 \mathrm{~mm}$

61

$\operatorname{Max} 8.5 \mathrm{~kg}$

$\operatorname{Max} 20.2 \mathrm{~g} / \mathrm{cm} /$ wire

$1.2 \mathrm{~kg}$

$3.2 \mathrm{~kg}$

$10 \mathrm{~m} / \mathrm{min}$

$67 \mathrm{cycle} / \mathrm{min}$

$7 \mu \mathrm{m}$

$3870 \mathrm{~m}$
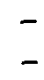

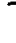

-

$-$ 


\section{SAMPLE CUTTING DATA SHEET (Cont.) \\ DEMONSTRATION 8 \\ 8 Nov. 1977}

\section{Remarks}

1. After $6 \mathrm{hr} 27 \mathrm{~min}$ from cutting start, the wire broke down, so operation had to be abandoned.

Failure may have been caused by the peeling off of right dummy glass.

At wire breaking, a bond for this dummy glass peeled of $f$ where softened, and so we concluded that this operation could not continue. 
TIME-VERTICAL POSITION DATA SHEET

DEMONSTRATION 8

8 Nov. 1977

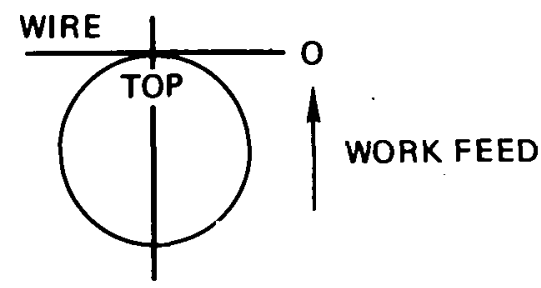

\begin{tabular}{|c|c|c|c|c|c|c|c|}
\hline $\begin{array}{l}\text { Time, } \\
\text { Hr-Min }\end{array}$ & $\begin{array}{c}\text { Vert. } \\
\text { Pos., } \\
\text { mm }\end{array}$ & $\begin{array}{l}\text { Total } \\
\text { Weight, } \\
\text { kg }\end{array}$ & $\begin{array}{c}\text { Cycle/ } \\
\text { Min } \\
\end{array}$ & $\begin{array}{l}\text { Time } \\
\text { Hr-Min }\end{array}$ & $\begin{array}{c}\text { Vert. } \\
\text { Pos., } \\
\text { mm }\end{array}$ & $\begin{array}{c}\text { Total } \\
\text { Weight, } \\
\text { kg }\end{array}$ & $\begin{array}{c}\text { Cycle/ } \\
\text { Min }\end{array}$ \\
\hline $0-00$ & 0 & 1.5 & 67 & $4-10$ & 46.3 & 8.5 & 67 \\
\hline 05 & 0.7 & 2.0 & 67 & 25 & 49.5 & 8.5 & 67 \\
\hline 10 & 2.0 & 2.5 & 67 & 40 & 52.3 & 8.5 & 67 \\
\hline 15 & 2.7 & 3.0 & 67 & 55 & 54.5 & 8.5 & 67 \\
\hline 20 & 4.4 & 3.5 & 67 & $5-10$ & 57.0 & 8.5 & 67 \\
\hline 25 & 5.9 & 4.0 & 67 & 25 & 59.5 & 8.5 & 67 \\
\hline 30 & 7.0 & 4.5 & 67 & 40 & 62.5 & 8.5 & 67 \\
\hline 35 & 8.0 & 5.0 & 67 & 55 & 65.0 & 8.5 & 67 \\
\hline 40 & 9.0 & 5.0 & 67 & $6-10$ & 67.5 & 8.5 & 67 \\
\hline 45 & 10.5 & 5.5 & 67 & 25 & 69.5 & 8.5 & 67 \\
\hline .50 & 11.0 & 6.0 & 67 & 27 & WIRE WAS & BROKEN & \\
\hline 55 & 12.0 & 6.5 & 67 & & & & \\
\hline $1-10$ & 15.5 & 7.0 & 67 & & & & \\
\hline 25 & 19.3 & 8.0 & 67 & & & & \\
\hline 40 & 22.5 & 8.5 & 67 & & . & & \\
\hline 55 & 25.9 & 8.5 & 67 & & & & \\
\hline $2-10$ & 28.2 & 7.0 & 67 & & & & \\
\hline 25 & 30.0 & 7.0 & 67 & & & & \\
\hline 40 & 32.7 & 7.0 & 67 & & & & \\
\hline 55 & 35.0 & 7.0 & 67 & & & & \\
\hline $3-10$ & 37.5 & 7.0 & 67 & & & & \\
\hline 25 & 39.7 & 7.0 & 67 & & & & \\
\hline 40 & 41.5 & 7.0 & 67 & . & & & \\
\hline 55 & 43.8 & 7.0 & 67 & & & & \\
\hline
\end{tabular}


THIS PAGE

\section{WAS INTENTIONALLY LEFT BLANK}


SAMPLE CUTTING DATA SHEET

DEMONSTRATION 9

9 Nov. 1977

Specification of Prospect

1. Materials of workpiece

2. Dimension of work

3. Machine No.

4. Cartridge type

5. Hour put to used of head rollers: $21 \mathrm{hr}, 12 \mathrm{~min}$

Cutting Condition

1. Roller pitch

$0.4 \mathrm{~mm}$

2. Diameter of wire

3. Abrasive

4. Lapping oil

5. Ratio of 3 to 4

$0.12 \mathrm{~mm}$

6. Bond

7. Mean amount of kerf

8. No. of wire under cutting

9. Total weight

10. Mean unit weight

11. Total wire tension

12. Breaking point of wire

13. Feeding amount of wire

14. Reciprocation of wire

15. Wears of wire

16. Total length of used wire

Silicon

中 $78 \times 28.4$

YQ-100 非143

Working Efficiency

1. Total working time

2. Number of works

3. Working time of unit work

Previous use No. 8

Sunlock SMD-01

$0.15 \mathrm{~mm}$

50

$\operatorname{Max} 6.9 \mathrm{~kg}$

Max $20 \mathrm{~g} / \mathrm{cm} /$ wire

$1.2 \mathrm{~kg}$

$3.2 \mathrm{~kg}$

$10 \mathrm{~m} / \mathrm{min}$

$65 \sim 67$ cycle/min

$7 \mu \mathrm{m}$

$5300 \mathrm{~m}$

4. Total cutting area

5. Total volumes of kerf

6. Mean volumes of kerf

$8 \mathrm{hr}, 50 \mathrm{~min}$

49 pcs

$10.8 \mathrm{~min}$

$2389 \mathrm{~cm}^{2}$

$35.8 \mathrm{~cm}^{3}$

$0.068 \mathrm{~cm}^{3} / \mathrm{min}$

\section{Schematics of Work Installed}

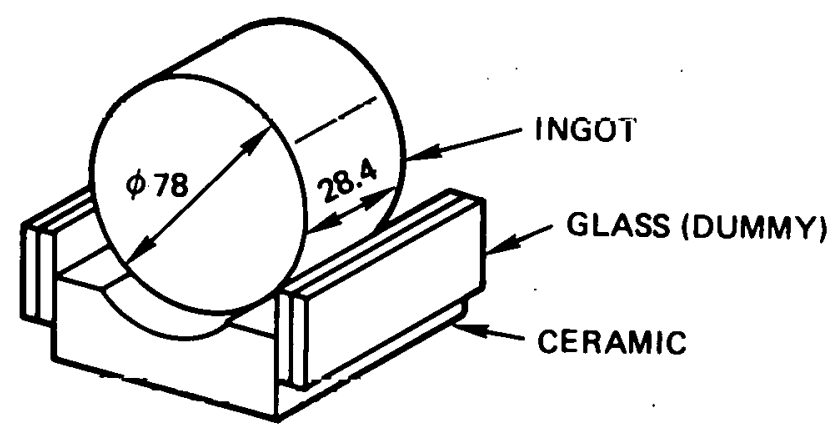




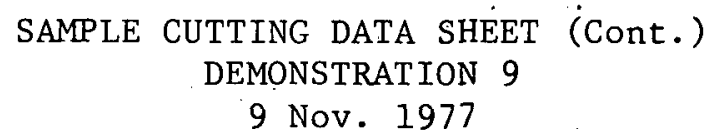

$\underline{\text { Remarks }}$

1. At 15 minutes from cutting start, total weight was decreased from $6.9 \mathrm{~kg}$ to $2.0 \mathrm{~kg}$ because of.. wire delaying.

2. At this time, wire cut $18 \mathrm{~mm}$ in silicon ingot. (See Time-Vertical Position Data Sheet.)

3. Investigation of sliced silicon wafers after cutting showed tool marks caused by wire on each wafer.

4. Total weight was changed radically under cutting operation. 

TIME-VERTICAL POSITION DATA SHEET DEMONSTRATION 9
9 Nov. 1977

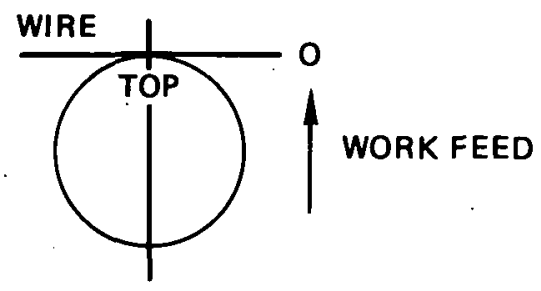

\begin{tabular}{|c|c|c|c|c|c|c|c|}
\hline $\begin{array}{l}\text { Time, } \\
\text { Hr-Min }\end{array}$ & $\begin{array}{l}\text { Vert: } \\
\text { Pos., } \\
\text { mm }\end{array}$ & $\begin{array}{l}\text { Total } \\
\text { Weight, } \\
\text { kg }\end{array}$ & $\begin{array}{c}\text { Cycle/ } \\
\text { Min }\end{array}$ & $\begin{array}{l}\text { Time, } \\
\text { Hr-Min }\end{array}$ & $\begin{array}{l}\text { Vert. } \\
\text { Pos., } \\
\text { mm }\end{array}$ & $\begin{array}{c}\text { Total } \\
\text { Weight, } \\
\text { kg }\end{array}$ & $\begin{array}{c}\text { Cycle/ } \\
\text { Min }\end{array}$ \\
\hline 00 & 0 & -1.5 & 65 & $3-10$ & 33.0 & 5.5 & 67 \\
\hline 05 & 1.2 & 2.0 & 67 & 25 & 35.5 & 5.5 & 67 \\
\hline 10 & 2.3 & 2.5 & 67 & 40 & 37.5 & 5.5 & 67 \\
\hline 15 & 4.0 & 3.0 & 67 & 55 & 39.7 & 5.5 & 67 \\
\hline 20 & 5.5 & 3.5 & 67 & $4-10$ & 41.8 & 5.5 & 67 \\
\hline 25 & $6.8^{\circ}$ & 4.0 & 67 & 25 & 44.0 & 5.5 & 67 \\
\hline 30 & 8.0 & 4.5 & 67 & 40 & 46.2 & 5.5 & 67 \\
\hline 35 & 9.5 & 5.0 & 67 & 55 & 48.4 & 5.5 & 67 \\
\hline 40 & 10.7 & 5.5 & 67 & $5-10$ & 50.6 & 5.5 & 67 \\
\hline 45 & 12.0 & 6.0 & 67 & 25 & 53.5 & 5.5 & 67 \\
\hline 50 & 1.4 .0 & 6.5 & 67 & 40 & 55.5 & 5.5 & 67 \\
\hline 55 & 15.5 & 6.9 & 67 & 55 & 58.0 & 5.5 & 67 \\
\hline $1-10$ & 18.8 & 6.9 & 67 & $6-10$ & 60.6 & 5.5 & 67 \\
\hline 15 & 18.0 & 2.0 & 67 & 25 & 63.5 & 5.5 & 60 \\
\hline 25 & 18.8 & 2.0 & 67 & 40 & 65.5 & 5.5 & 60 \\
\hline 40 & 19.0 & 2.5 & 67 & 55 & 66.5 & 5.5 & 60 \\
\hline 45 & 19.8 & 3.0 & 67 & $7-10$ & 67.6 & 5.5 & 60 \\
\hline 50 & 20.2 & 3.5 & 67 & 23 & $6 y .2$ & 3.5 & 60 \\
\hline 55 & 21.0 & 4.0 & 67 & 40 & 70.5 & 5.5 & 60 \\
\hline $2-00$ & 22.0 & 4.5 & 67 & . $\quad 55$ & 72.5 & 5.5 & 60 \\
\hline 5 & 23.0 & 5.0 & 67 & $8-10$ & 73.6 & 5.5 & 60 \\
\hline 10 & 24.0 & 5.5 & 67 & 25 & 75.6 & 5.5 & 60 \\
\hline 25 & 26.5 & 5.5 & 67 & 40 & 77.0 & 5.5 & 60 \\
\hline 40 & 28.4 & 5.5 & 67 & 50 & 78.0 & 5.5 & 60 \\
\hline 55 & 31.0 & 5.5 & 67 & & & & \\
\hline
\end{tabular}




\section{SLICE THICKNESS DATA SHEET \\ DEMONSTRATION 9 \\ 9 Nov. 1977}
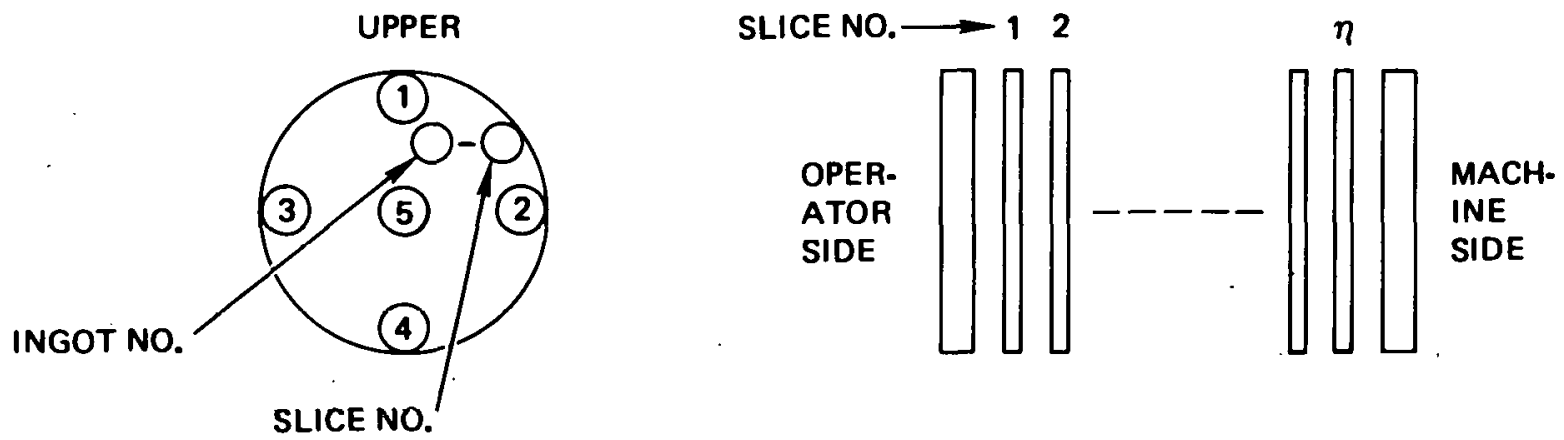

\begin{tabular}{cccccc}
\hline & $(1)$ & $(2)$ & $(3)$ & $(4)$ & $(5)$ \\
Slice. No. & $\mathrm{mm}$ & $\mathrm{mm}_{\mathrm{mm}}$ & 0.282 & 0.277 & 0.296 \\
1 & 0.266 & 0.288 & 0.275 & 0.262 \\
5 & 0.270 & 0.264 & 0.265 & 0.275 \\
10 & 0.265 & 0.263 & 0.262 & 0.265 & 0.265 \\
15 & 0.254 & 0.265 & 0.260 & 0.260 & 0.264 \\
20 & 0.272 & 0.264 & 0.266 & 0.265 & 0.264 \\
25 & 0.262 & 0.265 & 0.263 & 0.261 & 0.269 \\
30 & 0.272 & 0.264 & 0.269 & 0.279 & 0.271 \\
35 & 0.268 & 0.264 & 0.262 & 0.270 & 0.266 \\
40 & 0.267 & 0.269 & 0.268 & 0.276 & 0.269 \\
45 & 0.267 & 0.262 & 0.263 & 0.264 & 0.268 \\
49 & 0.255 & 0.257 & 0.253 & 0.261 & 0.257 \\
& & & & & \\
\end{tabular}




\section{SAMPLE CUTTING DATA SHEET \\ DEMONSTRATION 10 \\ 10 and 12 Nov. 1977}

\section{Spečification of Prospect}

1. Materials of workpiece

2. Dimension of work

3. Machine No.

4. Cartridge type

5. Hour put to used of head rollers

Silicon

$\phi 78 \times 26.7$

YQ-100 \#143

"G"

$0 \mathrm{hr}, 0 \mathrm{~min}$

Cutting Condition

1. Roller pitch

2. Diameter of wire

3. Abrasive

4. Lapping oil

5. Ratio of 3 to 4 \}

6. Bond

7. Mean amount of kerf

8. No. of wire under cutting

9. Total weight

10. Mean unit weight

11. Total wire tension

12. Breaking point of wire

13. Feeding amount of wire

14. Reciprocation of wire

15. Wears of wire

16. Total length of used wire

$0.4 \mathrm{~mm}$

$0.1 \mathrm{~mm}$

Previous use No. 6 - No. 9

Sunlock SMD-01

$0.13 \mathrm{~mm}$

56

$\operatorname{Max} 3.0 \mathrm{~kg}$

$\operatorname{Max} 7.8 \mathrm{~g} / \mathrm{cm} /$ wire

$0.9 \mathrm{~kg}$

$2.2 \mathrm{~kg}$

$10 \mathrm{~m} / \mathrm{min}$

$40-65$ cycle/min

$5 \mu \mathrm{m}$

$-$

Working Efficiency

1. Total working time

2. Number of works

3. Working time of unit work.

4. Total cutting area

5. Total volumes of kerf

6. Mean volumes of kerf

\section{Schematics of Work Installed}

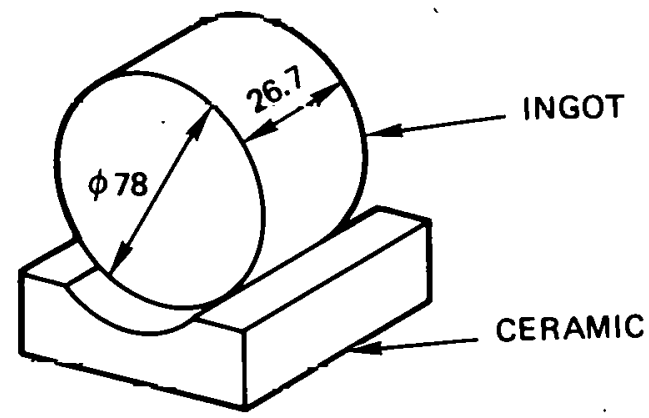




\section{SAMPLE CUTTING DATA SHEET. (Cont.) \\ DEMONSTRATION 10 \\ 10 and 12 Nov. 1977}

\section{Remarks}

1. November 10th 1977

a. After 13 minutes, cutting in $2 \mathrm{~mm}$ from starting, wire broke down. At this time, total weight was $1.5 \mathrm{~kg}$ and wire was barely worn, but threeroller set was a little injured.

b. Work was replaced; operation discontinued.

2. November 12 th 1977

d. Operated with new three-roller set with previously used $0.1 \mathrm{~mm}$ diameter wire and put together wire in previous cut slot.

b. Used MDC depth control to $4 \mathrm{~mm}$ depth from bottom of previous cut slot.

c. After $1 \mathrm{hr}-23 \mathrm{~min}$, wire broke once more. At this time, total weight was $3 \mathrm{~kg}$; wear of wire was $5 \mu \mathrm{m}$.

d. Wire breaking may have been caused by wire not fitting previous cut slot. The required cutting slot is as follows:

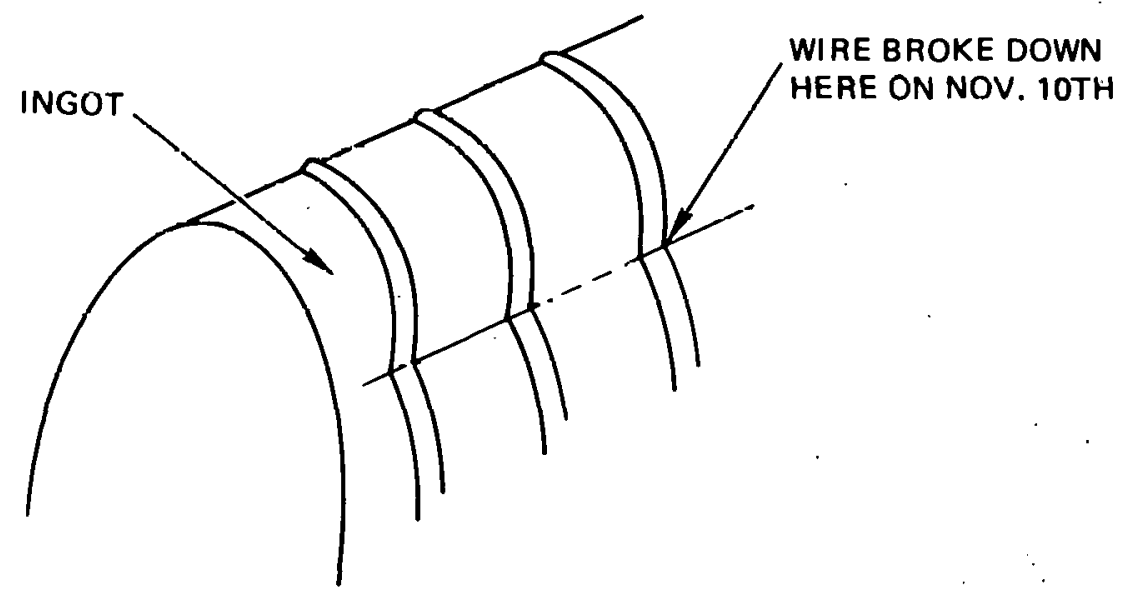


TIME-VERTICAL POSITION DATA SHEET

DEMONSTRATION 10

10 and 12 Nov. 1977

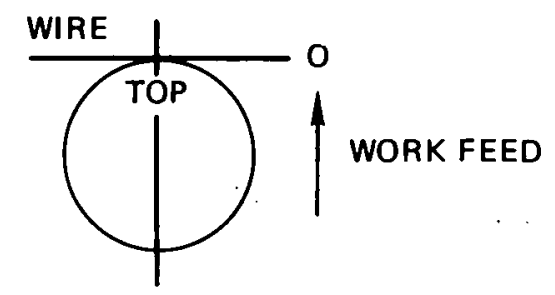

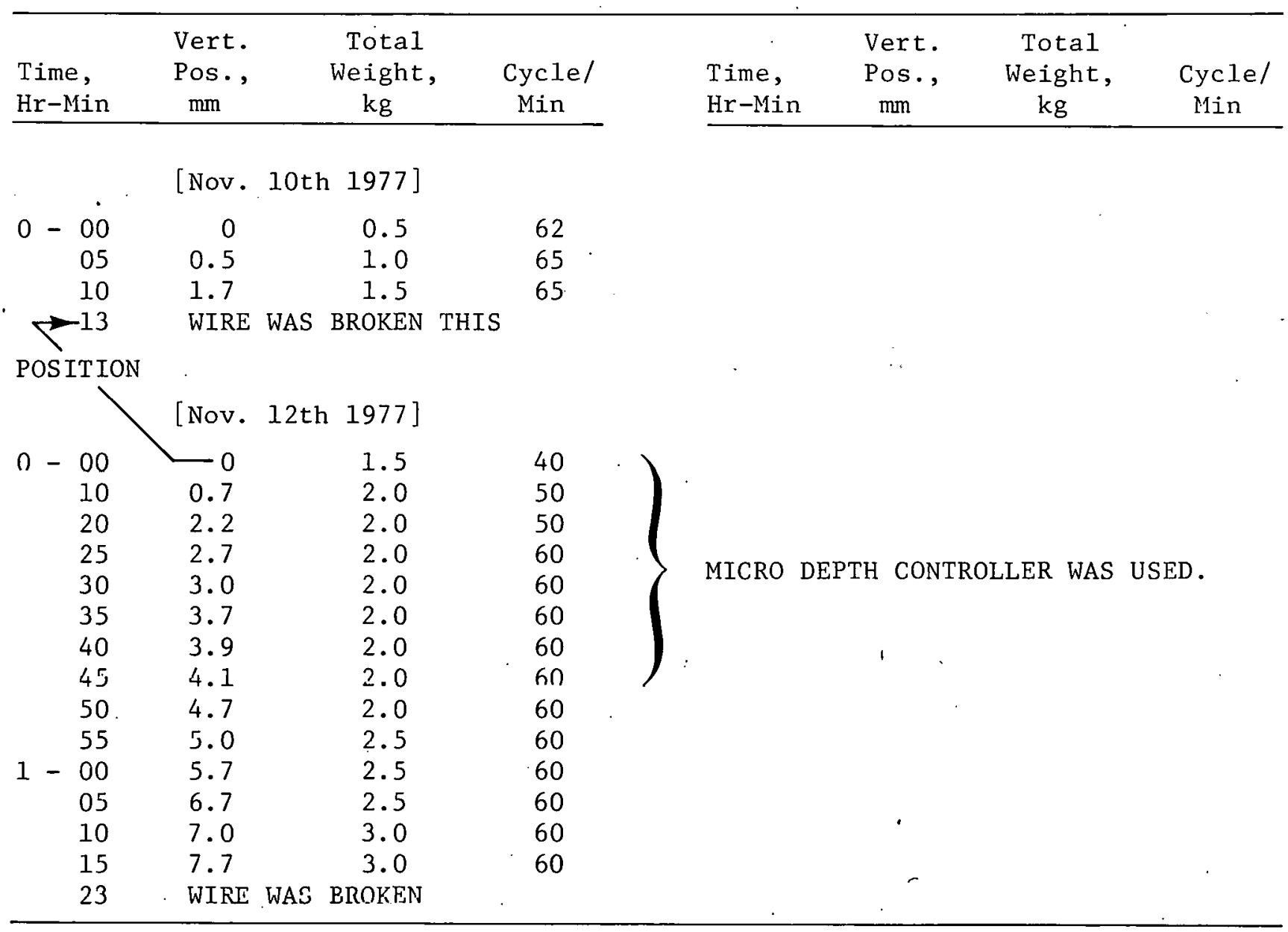


jpl $\geq$ PUBLICATION 78-37 